\title{
AVALIAÇÃO DE PARÂMETROS AGRONÔMICOS E NUTRICIONAIS EM HÍBRIDOS DE MILHO (Zea mays L.) PARA SILAGEM
}

\section{FRANCISCO NOGUEIRA DIAS}

Dissertação apresentada à Escola Superior de Agricultura "Luiz de Queiroz", Universidade de São Paulo, para obtenção do título de Mestre em Agronomia, Área de Concentração: Ciência Animal e Pastagens.

P I R A C I C A B A

Estado de São Paulo - Brasil

Maio- 2002 


\title{
AVALIAÇÃO DE PARÂMETROS AGRONÔMICOS E NUTRICIONAIS EM HÍBRIDOS DE MILHO (Zea mays L.) PARA SILAGEM
}

\section{FRANCISCO NOGUEIRA DIAS}

\author{
Engenheiro Agrônomo
}

Orientador: Prof. Dr. WILSON R. S. MATTOS

Dissertação apresentada à Escola Superior de Agricultura "Luiz de Queiroz", Universidade de São Paulo, para obtenção do título de Mestre em Agronomia, Área de Concentração: Ciência Animal e Pastagens.

P I R A C I C A B A

Estado de São Paulo - Brasil

Maio- 2002 


\section{Dados Internacionais de Catalogação na Publicação (CIP) DIMSÃO DE BIBLIOTECA E DOCUMENTAÇÃO - ESALQ/USP}

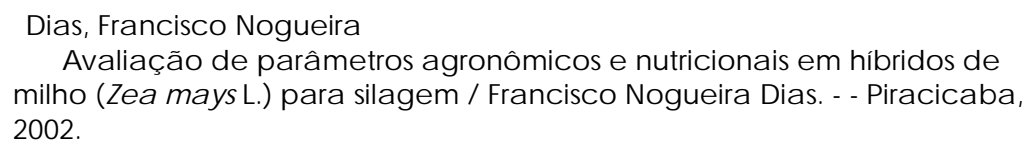

1. Bromatologia 2. Carateństicas agronômicas 3. Milho 4. Silagem Qualidade I. Título

CDD 633.15

\section{"Permitida a cópia total ou parcial deste documento, desde que citada a fonte - $O$ autor"}


Aos meus pais, Mario e Maria Aparecida, aos meus irmãos Maria Luiza, Gabriel, Ricardo e Carolina e a minha namorada Ieda. Pelo suporte, amor e carinho que sempre me deram em todos os momentos da minha caminhada. E, ao meu orientador Wilson R. S. Mattos. 


\section{AGRADECIMENTOS}

A Deus, Mestre dos Mestres e Senhor, por tudo que tem me proporcionado nesta vida.

À Escola Superior de Agricultura Luiz de Queiroz (USP) e em especial ao Departamento de Produção Animal - Setor de Ruminantes, pela oportunidade de realização deste curso.

Ao Prof. Dr. Wilson R. S. Mattos pela orientação segura, pelos ensinamentos valiosos, pela amizade, confiança e exemplo de dedicação profissional.

Ao Prof. Dr. Luiz Gustavo Nussio, pelas sugestões, idéias, colaboração e orientação na execução deste trabalho, pela amizade e exemplo profissional.

Ao Dr. José Manuel Corrêa de Simas, pelas sugestões, colaboração e auxílio na execução deste trabalho, pela amizade e exemplo profissional.

Aos demais professores do Departamento de Produção Animal, pelos ensinamentos, cordialidade e pela amizade.

Aos amigos e colegas de curso e república Victor Martus Marcon, Michel Alexandro Cambri, Rodrigo Michelini Coelho, Adriano Vechiatti Lupinacci, Eros A. B. Francisco, Ricardo Pereira Manzano, Hugo Imaizume, Carla Maris de Bittar Nussio, Liliane Suguisawa e Adriana Miranda pela amizade e pelo auxílio na condução das análises laboratoriais. 
Ao amigo Dr. Fábio Prudêncio de Campos pelas sugestões e auxílio na correção do trabalho escrito.

Ao funcionário do Laboratório de Bromatologia do Departamento de Produção Animal Carlos César Alves, pela amizade, paciência e ensinamentos durante as análises laboratoriais.

Aos demais funcionários e colegas do curso de pós-graduação, pela amizade, pela ajuda e pela agradável convivência.

Aos meus queridos pais Mario e Maria aparecida e irmãos Maria Luiza, Gabriel, Ricardo e Carolina, pela confiança, paciência e grande incentivo na execução deste trabalho.

A minha namorada e companheira, Ieda, pelo amor, confiança, incentivo e paciência durante o meu trabalho.

As pessoas que, direta ou indiretamente, contribuíram para a realização deste trabalho. 


\section{SUMÁRIO}

\begin{tabular}{|c|c|}
\hline & Página \\
\hline LISTA DE FIGURAS. & viii \\
\hline LISTA DE TABELAS.. & $\mathrm{x}$ \\
\hline RESUMO & xiv \\
\hline SUMMARY..... & $\mathrm{xvi}$ \\
\hline 1 INTRODUÇÃO.............. & 1 \\
\hline 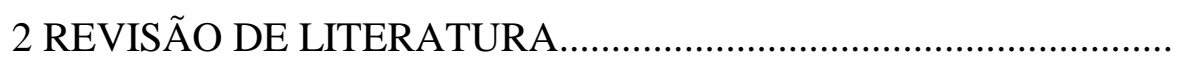 & 3 \\
\hline 2.1 Caracterização da planta de milho..... & 3 \\
\hline 2.1.2 Composição da planta de milho em suas diferentes partes............ & 3 \\
\hline 2.1.1 Composição bromatológica da planta de milho............................... & 4 \\
\hline 2.2 Contribuição das frações componentes da planta de milho na sua & \\
\hline qualidade.................................. & 6 \\
\hline 3 MATERIAL E MÉTODOS... & 14 \\
\hline 3.1 Características dos locais... & 14 \\
\hline 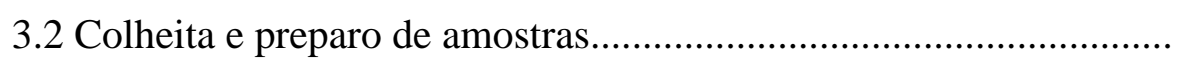 & 18 \\
\hline 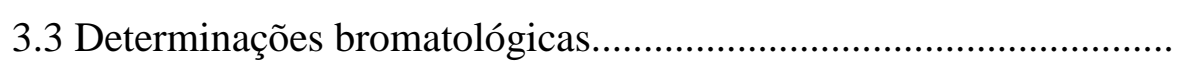 & 19 \\
\hline 3.4 Determinação da degradabilidade "in situ". & 20 \\
\hline 3.5 Estimativas de produção de leite por tonelada de MS de forragem & \\
\hline e por hectare... & 22 \\
\hline 3.6 Delineamento experimental e análise & 23 \\
\hline
\end{tabular}


4 RESULTADOS E DISCUSSÃO.................................................. 26

4.1 Características Agronômicas.............................................................. 26

4.1.1 Produções de matéria seca, matéria verde e população................. 26

4.1.2 Composição das partes da planta................................................... 30

4.2 Características bromatológicas...................................................... 34

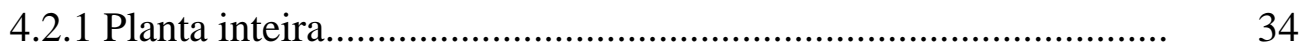

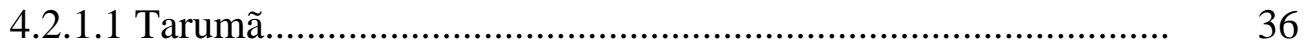

4.2.1.2 Мococa...................................................................... 48

4.2.1.3 Piracicaba........................................................................... 57

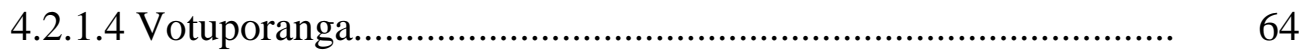

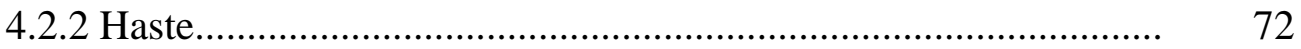

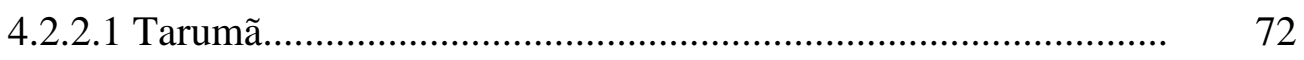

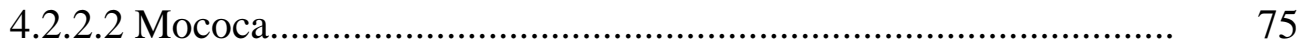

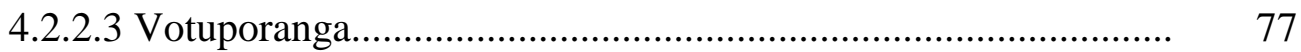

4.2.3 Estimativas de produção de leite por tonelada de MS de $\quad 79$

forragem e por hectare ..........................................................................

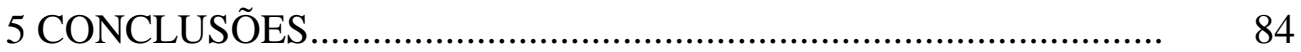

REFERÊNCIAS BIBLIOGRÁFICAS..................................................

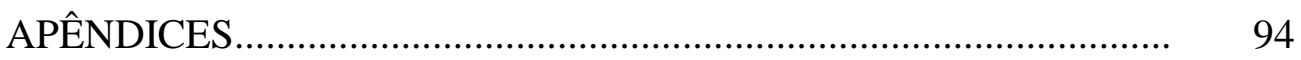




\section{LISTA DE FIGURAS}

Página

1 Relação entre a digestibilidade "in vitro" e a porcentagem de grãos na MS

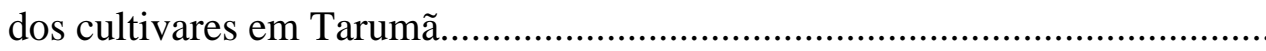

2 Relação entre a digestibilidade "in vitro" e a porcentagem de grãos na MS dos cultivares em Mococa................................................................................

3 Relação entre a digestibilidade "in vitro" e a porcentagem de grãos na MS dos cultivares em Piracicaba

4 Relação entre a digestibilidade "in vitro" e a porcentagem de grãos na MS dos cultivares em Votuporanga

5 Relação entre produção e qualidade da silagem de milho em Mococa.............

6 Relação entre produção e qualidade da silagem de milho em Votuporanga. 
8 Relação entre produção e qualidade da silagem de milho em

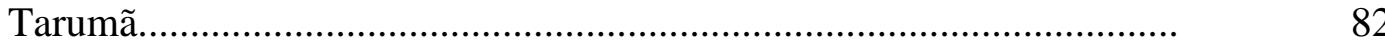




\section{LISTA DE TABELAS}

1 Frações da planta de milho encontradas por diversos autores

Página

3

2 Análise química do solo das áreas experimentais dos quatro locais em que

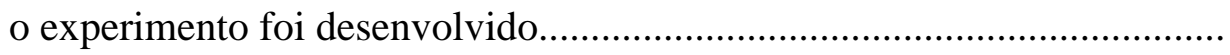

3 Caracterização dos híbridos de milho utilizados no experimento................

4 Caracterização do plantio dos híbridos para silagem

5 Análise de variância do experimento dentro de um local...........................

6 Análise de variância do experimento na interação local x híbrido

7 Produção de grãos, massa verde e matéria seca, porcentagem de MS e população dos cultivares de milho

8 Frações da planta de milho nas cidades de Tarumã, Mococa, Piracicaba e Votuporanga...... 
9 Nível de significância, média, $\mathrm{CV}$ e fontes de variação da análise bromatológica de cultivares de milho.......................................................

10 Parâmetros Agronômicos e frações químicas dos cultivares em Tarumã......

11Frações químicas dos cultivares em Tarumã

12 Correlações entre as principais características agronômicas e frações

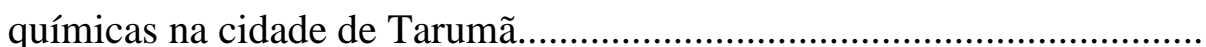

13 Coeficientes de correlação linear de Pearson determinados entre as variáveis dos cultivares em Tarumã.

14 Parâmetros agronômicos e frações químicas dos cultivares em Mococa...

15 Frações químicas dos cultivares em Mococa.

16 Correlações entre as principais características agronômicas e frações químicas em Mococa........................................................................

17 Coeficientes de correlação linear de Pearson determinados entre as variáveis dos cultivares em Mococa......................................................... 
18 Parâmetros agronômicos e frações químicas dos cultivares em

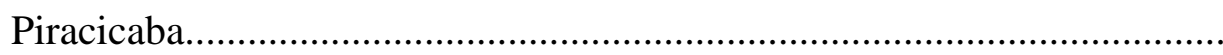

19 Frações químicas dos cultivares em Piracicaba.

20 Correlações entre as principais características agronômicas e frações químicas em Piracicaba.

21 Coeficientes de correlação linear de Pearson determinados entre as variáveis dos cultivares em Piracicaba..

22 Parâmetros agronômicos e frações químicas dos cultivares em Votuporanga.

23 Frações químicas dos cultivares em Votuporanga.

24 Correlações entre as principais características agronômicas e frações químicas em Votuporanga.

25 Coeficientes de correlação linear de Pearson determinados entre as variáveis dos cultivares em Votuporanga. 
26 Frações químicas da haste nos cultivares em Tarumã..............................

27 Coeficientes de correlação determinados entre as variáveis da haste em

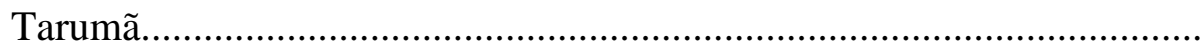

28 Frações químicas da haste nos cultivares em Mococa............................... 76

29 Coeficientes de correlação determinados entre as variáveis da haste em

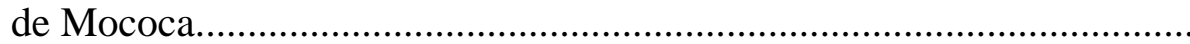

30 Frações químicas da haste nos cultivares em Votuporanga

31 Coeficientes de correlação determinados entre as variáveis da haste em 


\section{AVALIAÇÃO DE PARÂMETROS AGRONÔMICOS E NUTRICIONAIS EM HÍBRIDOS DE MILHO (Zea mays L.) PARA SILAGEM}

Autor: FRANCISCO NOGUEIRA DIAS

Orientador: Prof. Dr. WILSON R. S. MATTOS

\section{RESUMO}

A porcentagem de grãos na MS é um dos principais parâmetros utilizados na determinação da qualidade do milho para silagem. A partir da década de 80 alguns trabalhos mostraram a importância da porção volumosa da planta na digestibilidade e valor nutritivo da silagem. Este trabalho avaliou as características agronômicas, frações químicas, digestibilidade da planta e potencial de produção de leite em vinte híbridos testados em quatro localidades do Estado de São Paulo. O material foi colhido quando os grãos atingiram o ponto de maturidade ( $2 / 3$ da linha de leite), sendo esse dividido em grãos, espiga, haste e folhas, para análise posterior. Primeiramente, todas as amostras foram analisadas por espectroscopia (NIRS), para definir quais delas deveriam ser analisadas pela metodologia convencional com a finalidade de melhorar as curvas de 
predição. Segundo, as amostras selecionadas foram analisadas para se determinar os teores de FDN, FDN digestível, amido e amido digestível. E em terceiro, esses resultados obtidos foram utilizados para calcular a equação de regressão para estimar os teores de MS, FDN, FDN digestível, FDA, amido, amido digestível, EE, MM, proteína e digestibilidade "in vitro" da haste e da planta toda. Estes resultados foram utilizados para se determinar as correlações entre dados agronômicos e frações químicas, e estimar o potencial de produção de leite utilizando-se a planilha de Schwab e Shaver (Milk 2000) em cada localidade. Os resultados obtidos nas quatro localidades mostraram que na média a haste, espiga, grãos e folhas constituem 56, 27, 35 e 17\% da planta, respectivamente. Os teores médios de FDN, FDNd, amido, amidod foram 55, 60,9, 22,6 e 99,97\%, respectivamente. A DIVMS apresentou grande variação entre cultivares e locais (51,7 a 70,9\%). A FDN e FDA foram negativamente correlacionadas com a DIVMS (-0,60 e -0,50, respectivamente), sendo que o teor e a digestibilidade do amido, e a FDN foram positivamente correlacionados coma DIVMS (0,43, 0,62 e 0,41, respectivamente). O potencial médio de produção de leite estimado foi acima de 30.000 litros de leite por hectare e 1.300 litros de leite por ton de MS de forragem. 


\title{
AGRONOMIC AND NUTRITIONAL CHARACTERISTICS OF CORN HYBRIDS FOR SILAGE
}

\author{
Author: FRANCISCO NOGUEIRA DIAS \\ Adviser: Prof. Dr. WILSON R. S. MATTOS
}

\section{SUMMARY}

Corn that is to be harvested for silage is usually selected from existing grain hybrids. Recent evidence suggests that improved nutritive value of corn silage could be achieved through selection for high stover fiber digestibility. Agronomic and nutritive characteristics and milk production potential of twenty corn hybrids were evaluated at four sites in the state of Sao Paulo. Plants were harvested when the milk line had progressed 2/3 down from the top of the kernel. The material was fractioned into stem, leaves and ears + husk to determine the agronomic parameters; nutritional characteristics were estimated in whole-plant corn and corn stover. All samples were spectroscopically analyzed (NIRS); NDF, digestible NDF, starch and digestible starch were analyzed by the conventional wet chemistry analytical methodology in $45 \%$ of the samples. The improved prediction equations were used to estimate the percentage of DM, NDF, 
digestible NDF, FDA, starch, digestible starch, EE, MM, protein and IVDMD. Milk production potential was estimated by the worksheet proposed by Schwab and Shaver (Milk 2000). Stover, ear+husk, kernel and leaves overall mean percentages were 56, 27 , 35 and 17\%, respectively. NDF, digestible NDF, starch and digestible starch overall mean percentages were 55, 61, 23 and 100\%, respectively. IVDMD showed a large variation among hybrids and sites (51.7 to 70.9\%). NDF and ADF were negatively correlated to IVDMD (-0.6 and -0.5) and starch content, starch digestibility and NDF digestibility were positively correlated to $\operatorname{IVDMD}(0.43,0.62$ and 0.41 , respectively). Overall estimated potential milk production means were 30,000 liters per hectare and 1,300 liters per ton of forage dry matter. 


\section{INTRODUÇÃO}

Com a evolução da pecuária os sistemas de produção intensivos passaram a ser uma opção para os produtores brasileiros, e conseqüentemente a utilização de forragem de alta qualidade durante o ano todo passa a ser importante componente do sistema. Ao longo dos últimos anos houve a intensificação das técnicas de conservação de forragens, sendo a ensilagem o processo mais preponderante no sistema produtivo. Tradicionalmente, o material mais utilizado para ensilagem é a planta de milho, cultivado com este propósito em grandes áreas ao redor do mundo (McDonald et al., 1991). Este fato deve-se principalmente às suas características químico-bromatológicas

que a planta de milho possui para a confecção de boa silagem, como por exemplo: a quantidade adequada de carboidratos solúveis e baixo poder tampão necessário na formação de ambiente adequado para a fermentação microbiana.

Apesar de toda a difusão da silagem de milho como alimento volumoso, verificase ainda a utilização de conceitos equivocados na escolha de cultivares, tratos culturais e no processo de ensilagem, onde a qualidade do produto final não é priorizada.

Inúmeros fatores devem ser observados para se determinar a qualidade da silagem de milho, sendo que na década passada a avaliação da qualidade era realizada somente através da porcentagem de grãos na matéria seca. Segundo Silva (1997) isto ocorreu devido ao grande número de trabalhos, desenvolvidos até a década de 70, demonstrarem que os grãos de milho são mais digestíveis do que as folhas e hastes da planta e sendo assim, aumentando-se a sua proporção na silagem, aumentar-se-ia a qualidade desse volumoso. 
No entanto, a partir da década de 80, alguns trabalhos (Nussio, 1997; Oliveira, 1997, Givens et al., 2001) mostraram que a digestibilidade da porção volumosa também deveria ser avaliada no processo de determinação da qualidade do material a ser ensilado. A importância dessa fração foi demonstrada de forma mais clara por Caetano (2001) ao analisar as frações colmo, folha, palhas e sabugo. Esse autor observou que estas frações totalizam cerca de $70 \%$ do total de MS da planta, e contribuem com cerca de 39 unidades percentuais na digestibilidade "in vitro" da planta toda, o que representa cerca de $65 \%$ da digestibilidade potencial dessa planta.

Wolf et al.(1993) também constataram que a fração haste compreende mais de $50 \%$ da composição da MS da planta e, portanto, pode influenciar a produção de MS e o valor nutritivo da planta de milho. Esses resultados demonstram que grande parte dos trabalhos de seleção de híbridos para silagem foram conduzidos de forma incompleta no passado quando se associou em qualidade de volumoso como sinônimo de quantidade de grãos no volumoso. Hoje sabe-se que a porção vegetativa (haste + folha) representa papel importantíssimo na determinação da qualidade total da cultura para silagem.

O objetivo desse trabalho foi avaliar a relação entre as características agronômicas (produção de MS), relacionada com a composição químico-bromatológica das partes da planta (haste e planta toda) e da qualidade da silagem de milho estimada através da digestibilidade da MS e da produção de leite por tonelada de MS estimada pelo programa Milk2000 (Shaver et al., 2001). 


\section{REVISÃO DE LITERATURA}

\subsection{Caracterização da planta de milho}

\subsubsection{Composição das frações da planta de milho}

A composição das frações da planta de milho tem influência direta na qualidade da planta de milho. A variação dessas frações, em virtude de fatores genotípicos e fenotípicos, tem conseqüências diretas na produção e composição da planta de milho.

Na Tabela 1 verificam-se sete estudos de avaliação da composição da planta de milho nas suas diversas frações.

Tabela 1. Frações da planta de milho encontradas por diversos autores

\begin{tabular}{|c|c|c|c|c|c|}
\hline \multirow[b]{2}{*}{ Autores } & \multicolumn{5}{|c|}{ Frações da planta de milho* } \\
\hline & Grãos & Espiga & Colmo & Folha & Sabugo \\
\hline & $\begin{array}{c}---- \\
--1\end{array}$ & $\begin{array}{c}---- \\
---1\end{array}$ & $\%$ & 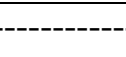 & ----- \\
\hline Oliveira et al. (1997) & 26 & - & 29 & 14 & 10 \\
\hline Caetano (2001) & 31 & 58 & 28 & 14 & 11 \\
\hline Almeida Filho (1996) & 35 & 45 & & & 10 \\
\hline Nussio e Manzano (1999) & 28 & - & - & - & - \\
\hline Thomas et al. (2001) & 51 & - & 24 & 11 & 7 \\
\hline Ballard et al. (1999) & 44 & - & 28 & 12 & 9 \\
\hline Mahanna (1996) & 46 & 54 & 36 & - & - \\
\hline
\end{tabular}


Através deles verifica-se que as porcentagens de grãos, espigas, colmo, folhas e sabugo variaram de 26 a $51 \%, 45$ a $72 \%, 16$ a $36 \%, 11$ a $14 \%, 7$ a $13 \%$, respectivamente, dependendo do autor .

Portanto, constata-se que existe grande variação dos cultivares quanto às frações da planta de milho, tanto entre os cultivares e/ou híbridos como também dentro do mesmo cultivar, devido a fatores como clima, fertilidade, adubação tratos culturais, etc. que atuam sobre a planta. $\mathrm{E}$ as frações que possuem a maior porcentagem da planta de milho são os grãos, variando de 30 a $40 \%$, e o colmo entre 25 a $35 \%$ ou a espiga e a haste, esta última sendo definida como todas as frações componentes da planta menos a fração grãos (Seglar, 2000) variando entre 30 e 50\% da planta de milho.

\subsubsection{Composição bromatológica da planta de milho}

A composição bromatológica da planta de milho varia sensivelmente conforme a densidade de plantio, época de colheita, cultivares e os fatores climáticos.

Hunt et al. (1992) mostraram que na fração espiga conforme a maturidade avança, passando de $1 / 3$ da linha do leite para 1/1, a porcentagem de matéria seca da planta aumenta (49,6\% para 64,8\%). Demonstram também que os itens que mais se destacam na fração espiga, são o amido (50,8\% para 62,4\%) e o FDN (26,4\% para 23,0\%), e também sofrem variações com o avanço da maturidade.

$\mathrm{Na}$ fração colmo os mesmos autores também demonstraram que os parâmetros relacionados à fibra são os que mais variaram, sendo o FDN a característica mais representativa e a que sofre maior aumento na sua porcentagem com o avanço da linha do leite no grão. Na planta toda, a fração amido apresenta um aumento com o avanço da maturidade, já a fração FDN uma tendência de redução.

Neste mesmo sentido, Phipps et al. citado por MacDonald (1991) mostraram diferenças na composição química da planta inteira de milho em três épocas de colheita. A matéria seca variou de 23,6\% para 33,5\% aos 96 e 138 dias, respectivamente, após a emergência. Outro componente que sofreu grande variação foi a quantidade de amido na planta, variando de $7 \%$ até $27,8 \%$ aos 96 e 138 dias após a emergência, respectivamente. 
Os carboidratos solúveis sofreram redução de $30,7 \%$ para $8,01 \%$ da planta toda durante o mesmo período. E a porção fibra sofreu pouca variação, com FDN passando de 41,3 para 43,2\% e o FDA de 21,7 a 22,3\% da planta de milho aos 96 e 138 dias após a emergência, respectivamente.

Já Thomas et al. (2001) não observaram diferenças entre os cultivares N29-F1 e NX 3018 em relação aos parâmetros FDN e amido. O cultivar N29-F1 apresentou teor de amido de 40,6\% na MS enquanto o NX 3018 de 37,0\%, no caso do FDN os teores foram de 39,6\% e 41,6\% respectivamente, sendo que o cultivar N29-F1 possuía teor de MS maior (41,3\%) do que o cultivar NX3018 (36,9\%).

Sapienza (1996), demonstrou ao compilar dados de diversos cultivares em diferentes anos que os maiores parâmetros químicos da planta de milho são a porção amido e a porção FDN, com o amido apresentando os maiores coeficientes de variação em todos os anos analisados. Quando houve separação das partes em haste e grãos, o autor verificou que o maior componente químico na porção haste da planta é o FDN representando quase $50 \%$ desta e aquele da fração grãos é o amido, com praticamente 70 $\%$ dela.

No mesmo trabalho, Sapienza (1996) observou variação numérica na composição química da planta ao avaliar diferentes cultivares, entretanto os parâmetros com maiores valores continuaram sendo o amido e o FDN; a variação na quantidade de grãos resultou em diferentes taxas de energia de líquida de lactação, sendo que a média para os diferentes cultivares em relação a porcentagem de grãos, amido, FDN e ELlactação foram $40 \% ; 27,12 \% ; 44,85 \%$ e $1,54 \mathrm{Mcal} / \mathrm{kg}$, respectivamente.

Com base nestas referências verifica-se que apesar da variação entre os cultivares e na composição química da planta, e indiferente ao avanço na maturidade da planta de milho constata-se que, as duas porções que mais representam a planta de milho são FDN e amido, e qualquer alteração nesses dois parâmetros representa grandes alterações na qualidade e valor nutritivo da planta de milho. 


\subsection{Contribuição das frações da planta de milho na sua qualidade}

Na produção de silagem de milho ou de sorgo de boa qualidade deve-se considerar não somente o percentual de grãos na massa ensilada, mas também os demais componentes da planta como um todo. Objetiva-se com isso a obtenção de silagem de qualidade o que propiciará melhor resposta animal nos diversos sistemas de produção, quer seja de leite ou de carne, bem como sua viabilidade econômica (RENTERO, 1998).

Segundo Bal et al. (2000) o valor nutritivo da planta de milho para silagem é afetado por vários fatores, tais como: a quantidade de grãos, o teor de FDN da fração haste, a digestibilidade do FDN, o teor de amido no grão, a digestibilidade do amido, o teor de óleo e a proteína.

NUSSIO \& MANZANO (1999) sugerem que em programas de seleção de cultivares de milho para a produção de silagem, os modelos de previsão de qualidade da silagem devem ser estabelecidos com base em dois fatores: porcentagem de grãos na massa ensilada (\% na MS) e valor nutritivo da porção haste+folhas (\% da digestibilidade verdadeira "in vitro" da MS).

Corrs et al. (1997) sugerem também que o valor nutritivo do milho usado para forragem, deve contemplar o teor de proteína, a digestibilidade e o potencial de consumo, sendo estes influenciados pela quantidade de grãos e composição da haste. $\mathrm{O}$ autor observa que os grãos são altamente digestíveis e caracteristicamente perfaz mais ou menos $50 \%$ do total da MS quando a planta é cultivada em boas condições. Quando a produção de grãos é reduzida por causa do stress, a qualidade da haste passa a ter maior importância. A haste é importante para promover o aumento do valor nutritivo da silagem de milho por conter a maioria dos carboidratos da parede celular, além disso, a digestibilidade da planta de milho é primariamente influenciada pela composição da fração parede celular (Merchen and Bourquin citado em Coors et al. 1997).

Essas considerações são contestadas por alguns autores, como por exemplo Allen et al. (1997), que não consideraram a produção de grãos um bom critério para a seleção de cultivares de milho para silagem, em virtude desses não estarem relacionados à qualidade da fração fibrosa e a produção de forragem. 
Silva et al. (1997) observaram que quanto maior for a proporção de espigas na MS da planta menor será a concentração de carboidratos não estruturais (CNE) na porção haste+folhas, e a digestibilidade ruminal dessa fração. Porém quando avaliaram a digestibilidade da planta inteira constataram que a proporção de espigas na MS pouco afetou os resultados obtidos. Segundo Silva et al. (1997), a alta variabilidade encontrada na degradabilidade da porção haste+folhas dos cultivares de milho ensilados, possibilitou a seleção de materiais em função da produção total de MS, dos teores FDN, FDA e da qualidade da fibra do material, melhor avaliada pelos teores de hemicelulose na FDN.

Penati (1995) observou que os componentes da parede celular são os fatores que mais interferem na qualidade da MS da planta de milho, sendo a lignina o componente mais representativo. A porcentagem de lignina da haste variou entre $6 \%$ a $12 \%$ e apresentou correlação baixa e negativa com a digestibilidade "in vitro" verdadeira da MS das hastes. Segundo o autor, esses resultados sugerem que a composição químicobromatológica e a disposição tridimensional da lignina ligada aos demais componentes da parede celular explicam melhor a qualidade da haste e/ou da planta do que propriamente a percentagem da lignina na haste.

Hunter (1978), verificou em diversos materiais com aptidão para a produção de grãos a existência de variabilidade entre os diversos genótipos, demonstrada através do consumo de MS e da digestibilidade da forragem, na porção que não representava os grãos, determinando assim, que a porção haste teria sua relevância na qualidade da planta de milho.

No mesmo sentido Allen et al. (1990), avaliando a digestibilidade de vários cultivares de milho constataram pequena variação entre eles quando comparados com as frações de grãos na MS e de FDA. Através destes dados os autores constataram que a porcentagem de grãos na MS não era o principal responsável pela digestibilidade da MS da planta, já que com diferentes proporções de grãos as digestibilidades da MS foram semelhantes, demonstrando que outros componentes da planta também estão envolvidos na qualidade da silagem de milho. 
Oliveira et al. (1997) avaliaram 11 cultivares de milho mostraram que o teor de grãos e a degradabilidade "in situ” da MS após 24h de incubação no rúmen (DISMS-24) não apresentaram alta correlação $\left(r^{2}=0,009\right)$, e que informações sobre a DISMS-24 da planta toda são mais confiáveis do que o teor de grãos para avaliar o melhor cultivar de milho para silagem. Concluíram que, em trabalhos visando o melhoramento genético da planta de milho para silagem a melhoria da digestibilidade da planta deve ser perseguida através da manipulação do porcentual das diferentes partes das plantas e das características qualitativas de cada uma dessas frações.

Wolf et al. (1993b) avaliaram diferentes cultivares de milho e demonstraram que a digestibilidade da planta de milho e a composição da parede celular possuem correlações mais fortes com a porcentagem de espigas e com a produção de haste do que com a produção de grãos e, que a porcentagem de espigas está associada com a produção de haste e não com a produção de grãos. Estes autores concluíram que a qualidade nutricional da haste possui fortes correlações com a qualidade nutricional da planta toda de milho, e portanto, tanto a qualidade como a quantidade de haste são fatores que influenciam a qualidade nutricional da planta toda, e que somente o aumento da produção de grãos pode não levar ao aumento da qualidade nutricional da planta de milho.

Wolf et al. (1993a) observaram que enquanto a fração grãos contribui com 50\% ou mais da produção da planta toda, e assim influencia marcantemente a sua digestibilidade, a quantidade de haste, relativamente menos digestível, pode levar a diminuição do incremento da qualidade atribuído à alta produção de grãos. E que baseado na análise de atributos de qualidade que esses autores realizaram neste trabalho comparando diferentes genótipos, fica demonstrado que, aumentos na qualidade nutricional da planta de milho podem ser alcançadas aumentado-se a digestibilidade da haste sem contudo sacrificar a produção de grãos da planta.

No Canadá a avaliação de 29 híbridos de milho para silagem durante o período de dois anos consecutivos por Vattikonda et al. (1983) mostraram correlação positiva entre a porcentagem de grãos na MS e a digestibilidade da planta inteira, além da interação 
entre a digestibilidade da fração volumosa e a planta inteira. Estes autores também demonstraram que ocorre variação muito maior na porção haste e folhas da planta do que na porção grãos ou na planta inteira, sendo esta mesma observação constatada por Coors (1996).

Coors (1996) ao estudar 33 híbridos (15 precoces e 18 tardios) constatou correlação positiva de 0,57 entre a porcentagem de espigas na MS e o teor de FDN na haste para os híbridos precoces e 0,81 para os tardios, apesar da correlação entre o FDN da planta toda e a quantidade de espigas da mesma ter sido correlacionada negativamente, -0,69 e - 0,46 para os híbridos precoces e tardios, respectivamente. Este autor não encontrou correlação entre a porcentagem de espigas na MS e digestibilidade da planta inteira assim como entre a produção de grãos e a digestibilidade da planta inteira, observações também encontradas no estudo feito por Sanderson et al (1995).

Deinum \& Bakker (1981) citado por Silva (1997), testaram na Holanda 27 híbridos em 1976 e 29 híbridos em 1978 em três locais e encontraram como resultados pequena correlação entre a porcentagem de grãos e a digestibilidade da planta inteira $(r=$ 0,48 e 0,49 para os anos de 1976 e 1978) e elevada correlação entre a digestibilidade da planta inteira e a digestibilidade da fração volumosa (haste + folhas) $(r=0,66$ e 0,78). A porcentagem de grãos na MS mostrou-se positivamente correlacionada com o teor de FDN da fração volumosa $(r=0,55$ e 0,68$)$, demonstrando assim um possível efeito de translocação de carboidratos solúveis da fração volumosa para a fração grãos, como sugerido por Russel et al. (1992).

Russel et al. (1992) avaliaram três híbridos em três maturidades diferentes e relataram que, com o avanço da maturidade da planta a relação grão : parte aérea era aumentada, sem que fosse afetada a degradabilidade "in vitro" da planta toda. Isto ocorreu provavelmente devido a uma "compensação" determinada pelo decréscimo na digestibilidade do colmo, impedindo que aumentos na participação de grãos na massa ensilada aumentassem a digestibilidade. 
Russel et al. (1986) demonstrou também que a digestibilidade "in vitro" da haste de milho decresce com o avanço da maturidade e que esta foi altamente correlacionada com o teor de FDA e lignina.

Nussio (1997) avaliou diferentes cultivares de milho em diferentes localidades quanto às características da planta de milho, observou que os fatores determinantes na qualidade da planta de milho para silagem foram o potencial produtivo de grão seguido da degradação da fração fibrosa. No entanto, o autor observou variação entre os híbridos em relação à fração fibrosa com alguns cultivares apresentando alta degradabilidade da fibra e dos teores de FDN, FDA e lignina; enquanto outros revelaram comportamento contrário com relação a esta fração. Com isto o ele concluiu ser necessário maiores estudos com relação à degradação da fração fibrosa.

Caetano (2001) observando o comportamento de híbridos em diferentes condições constatou correlação entre o teor de FDN e a porcentagem de folhas $(r=0,60)$ e colmo $(\mathrm{r}=0,55)$ na MS da planta. Também observou coeficientes de correlação significativos e negativos entre o teor de FDN e a porcentagem de grãos $(r=-0,61)$ e espigas $(r=-0,63)$ na MS da planta inteira. Quanto à digestibilidade verdadeira "in vitro" da MS (DVIMS), Caetano (2001) encontrou coeficientes de correlação negativos e significativos da DVIMS com os teores de FDN, FDA, hemicelulose, celulose e lignina; assim como foram obtidos coeficientes de correlação positivos e significativos entre o coeficiente da DVIMS e as porcentagens de MS da planta inteira e da fração grãos na MS da planta.

Johnson et al. (1999) verificaram em uma de revisão sobre o valor nutritivo da silagem, que a maturidade afeta os teores de amido, FDN, FDA e consequentemente a digestibilidade da planta de milho. Este autor também demonstra o conflito existente entre o desenvolvimento dos grãos e a qualidade da haste associada com o manejo da silagem de milho. Concluiu que a identificação de híbridos de milho que mantenham a qualidade da haste enquanto a quantidade de grãos aumenta com o avanço da maturidade da planta é uma estratégica lógica para o aumento da qualidade da silagem de milho.

Sonon et al. (1993), demonstraram que o aumento na porcentagem de grãos corresponderia a um aumento na qualidade da silagem. Esses autores retiraram a espiga 
da planta no momento da ensilagem e ensilaram o material reconstituído com a espiga triturada em proporções que variaram de 0 a $65 \%$ de grãos na MS. Ao fornecerem a silagem para carneiros, e avaliarem o consumo e a digestibilidade notaram um efeito benéfico da maior proporção de grãos na MS sobre o desempenho animal, uma vez que o consumo voluntário passou de 39,4 para 59,3 $\mathrm{g} \mathrm{MS} \mathrm{kg}^{-1}$ de peso metabólico e a digestibilidade da MS de 55,7 para 69,1\%. Estes autores também constataram neste estudo que a digestibilidade da fibra (FDA) diminuiu com o aumento da concentração de grãos passando de 45,9 para 35,1\%, melhorando assim a qualidade da planta de milho.

Hunt et al. (1991) demonstraram através da avaliação de dois híbridos de milho que apesar da semelhança na composição das suas respectivas frações (grãos, sabugo, espiga e haste) ocorreu diferença significativa nos teores de FDN e FDA e nas degradabilidades "in situ" e "in vitro" da planta toda. Estes autores observaram que o aumento na qualidade nutricional do híbrido 3377 foi mais em função do aumento na degradabilidade das características da haste do que diferenças na proporção de grãos na planta toda, sendo que o híbrido 3377 e o 3389 obtiveram 41\% e 44\% de grãos na MS, respectivamente. Concluíram que a colocação feita anteriormente não descaracteriza a importância da fração grão no aumento da qualidade dos híbridos de silagem de milho, mas demonstra a importância da qualidade da fração haste na determinação da qualidade da planta de milho.

Schmid et al. (1976) avaliaram 23 silagens oriundas de 11 híbridos de milho para determinar a importância da composição da planta e digestibilidade sobre a performance de ovinos. A porcentagem de grãos apresentou correlação positiva com a digestibilidade "in vivo" da MS, consumo de MS e ganho médio diário; enquanto os outros componentes apresentaram correlações negativas. A porcentagem de grãos na MS não apresentou correlação com a produção total.

Este mesmo autor encontrou que a silagem que apresentava elevada porcentagem de grãos (64\%), digestibilidade e consumo apresentou uma MS de 55,8\%, enquanto a silagem com menor digestibilidade, menor ganho médio diário e baixa porcentagem de grãos (16\%) apresentou 22,8\% MS. 
Também neste sentido, Lauer et al. (2001) ao estudarem a comparação entre cultivares utilizados no "Corn Belt" americano na década de 30 com os de 90 observaram que, nos últimos 70 anos aumentos em produção e qualidade da planta de milho como forragem foi atribuído ao aumento na produção de grãos, sendo que estes além de serem altamente degradáveis também reduzem a concentração de fibra e aumentam a digestibilidade. Concluíram que, pequenas alterações ocorreram na qualidade da porção haste dos híbridos de milho disponíveis na região do "Corn Belt".

Deinum (1988) observou que a alta proporção de variabilidade genotípica na digestibilidade da planta de milho foi devido a diferenças na digestibilidade da parede celular. Továr-Gomez et al. (1997) observaram que muito da resposta em performance animal associada com diferentes genótipos foi devido a diferenças na extensão da degradabilidade da parede celular no rúmen, e enfatiza a importância do conhecimento da qualidade da parede celular.

Já Nussio et al. (2001) observaram em resultados médios dos anos agrícolas de $1997 / 98$ e 1999/2000 que a proporção de haste na planta atingiu 24,15\% da MS com uma digestibilidade de 48,85\%, ou seja, uma contribuição estimada em 11,8 unidades percentuais na digestibilidade média total da MO, que foi de $62,15 \%$.

Estes mesmos autores também verificaram que a proporção média de grãos foi de $38,5 \%$ na MS podendo estes contribuir com cerca de 31 unidades percentuais na digestibilidade da planta ao considerar valores de aproximadamente $80 \%$ de digestibilidade dessa fração.

Outro aspecto que estes autores observaram foi que, as frações grãos e haste contribuem com cerca de 43 unidades percentuais da digestibilidade, o que representa cerca de $69 \%$ do potencial de digestibilidade média total da planta. Demonstrando assim, motivo suficiente para inclusão dessas frações em qualquer modelo de estimativa de qualidade da planta de milho.

Cox et al. (1994) estudaram a da interação entre híbridos comerciais com relação à qualidade desses e concluíram que, antes da melhoria dos híbridos de milho para forragem os produtores provavelmente deveriam continuar a escolher híbridos de milho 
com alta quantidade de grãos e se alta digestibilidade da fração fibra. Eles também verificaram que híbridos com alta quantidade de grãos, nem sempre são necessariamente associados com alta produção de MS.

Crasta et al. (1997) observaram diferentes fatores afetando a qualidade da planta de milho e constataram que, as concentrações de FDN e a digestibilidade da MS "in vitro" no estágio farináceo-duro da planta toda estão diretamente correlacionados com a lignina da haste e a quantidade de grãos, o que segundo os autores sugerem que ambas as características estão associadas com a qualidade da forragem de milho nas condições de ambientes do seu estudo (Nordeste dos EUA). 


\section{MATERIAL E MÉTODOS}

O experimento foi realizado entre os meses outubro de 2000 a março de 2001, e desenvolvido em 4 locais diferentes do Estado de São Paulo:

- Departamento de Produção Animal - ESALQ/USP - Piracicaba

- Estação Experimental do Instituto Agronômico - Votuporanga

- Usina Nova América - Tarumã

- Estação Experimental do Instituto Agronômico - Mococa

\subsection{Características dos Locais}

Em Piracicaba o trabalho foi desenvolvido no Departamento de Produção Animal, Setor de Ruminantes, da Escola Superior de Agricultura "Luiz de Queiroz" (ESALQ USP) - SP, localizada a $22^{\circ} 45^{\prime}$ de latitude sul, e $47^{\circ} 38^{\prime}$ de longitude oeste e altitude de 537 metros.

O solo da área experimental, cuja análise química se encontra na Tabela 2 é classificado, segundo Ranzani et al. (1966), citado por Guandique (1993), como Terra Roxa Estruturada (TER), série "Luiz de Queiroz". Segundo a classificação de Koeppen o clima da região é do tipo CWA ou seja subtropical úmido, verão chuvoso e inverno seco. 
Tabela 2. Análise química do solo das áreas experimentais dos quatro locais em que o experimento foi desenvolvido

\begin{tabular}{ccccccccccc}
\hline Local $^{*}$ & $\mathrm{pH}$ & $\mathrm{M} . \mathrm{O}$ & $\mathrm{P} \mathrm{resina}$ & $\mathrm{K}$ & $\mathrm{Ca}$ & $\mathrm{Mg}$ & $\mathrm{Al}+\mathrm{H}$ & $\mathrm{S}$ & $\mathrm{T}$ & $\mathrm{V}$ \\
& $\mathrm{CaCl}_{2}$ & $\mathrm{~g} \mathrm{dm}^{-3}$ & $\mathrm{mg} \mathrm{dm}^{-3}$ & ------------- & $\mathrm{mmol}_{\mathrm{c}} \mathrm{dm}^{-3}$ & & & & \\
\hline 1 & 5.2 & 26 & 31 & 5.3 & 34 & 16 & 38 & 55.3 & 93.3 & 59 \\
2 & 6 & 11 & 13 & 2.1 & 15 & 8 & 12 & - & 83.6 & 68 \\
3 & 6.3 & 25 & 38 & 2.8 & 45 & 21 & 15 & - & 37.1 & 82 \\
4 & 5.2 & 2.9 & 19 & 1.3 & 50 & 22 & 0 & - & 114 & 65 \\
\hline
\end{tabular}

"Local: 1. Piracicaba, 2. Votuporanga, 3. Mococa, 4. Tarumã.

Em Votuporanga o trabalho foi desenvolvido na Estação Experimental do Instituto Agronômico de Campinas (IAC) - SP, localizada a $20^{\circ} 25^{\prime} 02^{\prime}$ ' de latitude sul, e $49^{\circ}$ 58' de longitude este e altitude de 480 metros.

$\mathrm{Na}$ área experimental de Votuporanga, o solo, cuja análise química se encontra na Tabela 2, é classificado como LATOSSOLO VERMELHO eutrófico, Lve (Embrapa, 1999). O clima da região é subtropical úmido com temperatura média anual de $24^{\circ} \mathrm{C}$ (máxima de $37^{\circ} \mathrm{C}$ e mínima de $10^{\circ} \mathrm{C}$ ) e precipitação pluviométrica anual de $1.300 \mathrm{~mm}$.

$\mathrm{Na}$ cidade de Mococa o trabalho foi desenvolvido na Estação Experimental do Instituto Agronômico - SP, localizada a $21^{\circ} 27^{\prime}$ de latitude sul, e $47^{\circ} 00^{\prime}$ de longitude oeste e altitude de 665 metros.

O solo da área experimental, cuja análise química se encontra na Tabela 2, é classificado como ARGISSOLO VERMELHO eutroférrico, Ave (Embrapa, 1999). O clima da região é do tipo subtropical com duas estações bem definidas, inverno e verão e com precipitações pluviométricas de $1500 \mathrm{~mm}$ anuais.

Em Tarumã o trabalho foi desenvolvido na Usina Nova América - SP, localizada a $22^{\circ} 37^{\prime}$ de latitude sul, e $50^{\circ} 25^{\prime}$ de longitude oeste e a uma altitude de 537 metros. 
$\mathrm{Na}$ área experimental de Tarumã, o solo, cuja análise química se encontra na Tabela 2, tem o seu solo classificado como LATOSSOLO VERMELHO eutroférrico, Lvef (Embrapa, 1999). O clima da região de Tarumã é do tipo AW (classificação de Koeppen) com precipitações anuais variando entre 1200 a 1300mm.

Foram utilizados 20 cultivares oriundos de 8 empresas ou instituições, cujas características são apresentadas na Tabela 3, com 4 blocos espaçados entre si a uma distância de $5 \mathrm{~m}$. Cada bloco foi composto por 20 parcelas ou tratamentos, sendo que cada parcela representava um cultivar. A localização dos híbridos dentro de cada bloco foi determinada por sorteio.

As áreas experimentais foram preparadas convencionalmente, sendo realizadas uma aração (ou escarificação) e duas gradagens com grade niveladora, sendo a última feita antes da semeadura. Os sulcos para o plantio foram abertos por um sulcador cujas hastes estavam espaçadas entre si a uma distância de 0,8 m em Tarumã, Piracicaba e Votuporanga e de $0,9 \mathrm{~m}$ na cidade de Mococa. As parcelas foram constituídas por 4 linhas com $5 \mathrm{~m}$ de comprimento, sendo que as 2 linhas laterais foram consideradas como bordadura.

As sementes foram tratadas no dia anterior à semeadura com o produto Thiodicarb ${ }^{\circledR}$ mais micronutrientes (Futur da empresa Novartis) para o controle de pragas do solo e correção de micronutrientes. Para garantir a população ideal especificada pelas companhias de cada cultivar, foram semeadas $20 \%$ a mais de sementes, isto é, 10 sementes por metro linear, número este que permitiria após o desbaste, a população de 57.500 plantas/ha para as localidades de Tarumã, Votuporanga e Piracicaba e de 55.500 plantas/ha para a cidade de Mococa. A semeadura foi realizada manualmente com o auxílio de matracas sobre o sulco de plantio. Após 25 dias da semeadura foi realizado o desbaste manual para a redução do número de plantas. 
Tabela 3. Características dos híbridos de milho utilizados no experimento

\begin{tabular}{|c|c|c|c|}
\hline Empresa/Instituição & Cultivar & Tipo $^{*}$ & Ciclo Fenológico \\
\hline Monsanto & C 333B & $\mathrm{HSm}$ & Normal \\
\hline \multirow[t]{4}{*}{ ( Agroceres e Dekalb) } & C 747 & HTm & Precoce \\
\hline & AG 8080 & HS & Precoce \\
\hline & AG 4051 & HS & Normal \\
\hline & AG $1051\left({ }^{1}\right)$ & HD & Normal \\
\hline \multirow[t]{2}{*}{ Agromen } & AGN 2012 & HD & Superprecoce \\
\hline & AGN 3060 & HS & Superprecoce \\
\hline Aventis Seeds & A 3663 & HS & Precoce \\
\hline \multirow[t]{3}{*}{ Dow AgroSciences } & Dina 1000 & $\mathrm{HSm}$ & Precoce \\
\hline & Z 8420 & HS & Precoce \\
\hline & Z 8550 & HT & Semiprecoce \\
\hline \multirow[t]{2}{*}{ Syngenta Seeds } & Tork & HS & Precoce \\
\hline & Traktor & HD & Precoce \\
\hline \multirow[t]{4}{*}{ Pioneer } & P 3041 & HT & Precoce \\
\hline & P $30 \mathrm{~F} 33\left(^{2}\right)$ & HS & Precoce \\
\hline & P $30 F 80\left({ }^{3}\right)$ & HS & semiprecoce \\
\hline & P 30F44 & HS & Precoce \\
\hline Secretaria da Agricultura & AL 30 & $\mathrm{~V}$ & Semiprecoce \\
\hline Sementes Graúna & Graúna 183 & HD & Precoce \\
\hline \multirow[t]{3}{*}{ Pré Comercial } & XY 10 & HS & Precoce \\
\hline & XY 20 & HS & Precoce \\
\hline & XY 30 & $\mathrm{~V}$ & Normal \\
\hline
\end{tabular}

As adubações de semeadura e de cobertura foram realizadas conforme a análise de solo de cada local, e estão demonstradas também na Tabela 10, sendo que a adubação de cobertura foi realizada aos 25 e 50 dias após a emergência das plantas. Quando necessário foram efetuadas pulverizações na dosagem recomendada pelo fabricante do inseticida MATCH CE ${ }^{\circledR}$ (Novartis) para o controle da lagarta do cartucho (Spodoptera frugiperda). Também foram realizadas capinas manuais para o controle de plantas daninhas nas parcelas. 
Tabela 4. Caracterização do plantio dos híbridos para silagem

\begin{tabular}{|c|c|c|c|c|c|c|c|}
\hline \multirow{3}{*}{ Local } & \multirow{3}{*}{$\begin{array}{c}\text { Data de } \\
\text { semeadura }\end{array}$} & \multirow{3}{*}{$\begin{array}{c}\text { Espaç. } \\
\mathrm{cm}\end{array}$} & \multirow{3}{*}{$\begin{array}{c}\text { População } \\
\text { Final } \\
\text { pl/ha }\end{array}$} & \multicolumn{4}{|c|}{ Adubação } \\
\hline & & & & \multicolumn{2}{|c|}{ Plantio } & \multicolumn{2}{|c|}{ Cobertura } \\
\hline & & & & $\mathrm{kg} / \mathrm{ha}$ & Fórmula & $\mathrm{kg} / \mathrm{ha}$ & Fórmula \\
\hline \multirow[t]{2}{*}{ Tarumã } & $21 / 10 / 00$ & 80 & 57.143 & 330 & $04-20-20$ & $60+40$ & $20-0-$ \\
\hline & & & & & & & $20+\mathrm{SA}$ \\
\hline \multirow[t]{2}{*}{ Piracicaba } & $10 / 11 / 00$ & 80 & 56.489 & 400 & $08-28-$ & $60+40$ & 20-05- \\
\hline & & & & & $16+Z n$ & & $20+\mathrm{SA}$ \\
\hline \multirow[t]{2}{*}{ Votuporanga } & $20 / 11 / 00$ & 80 & 57.409 & 380 & $08-28-16$ & $60+40$ & 20-05- \\
\hline & & & & & & & $20+\mathrm{SA}$ \\
\hline Mococa & $11 / 12 / 00$ & 90 & 53.217 & 400 & $08-28-16$ & 120 & $20-05-20$ \\
\hline
\end{tabular}

\subsection{Colheita e preparo das amostras}

O ponto de colheita foi determinado através da observação das plantas do mesmo cultivar, quando a maioria das plantas apresentou textura de grãos entre pastosa (1/3 da linha do leite) até farináceo-duro (2/3 da linha do leite) (Nussio et al., 1999). Todas as parcelas foram colhidas no mesmo dia.

Antes de promover o corte à altura de $5 \mathrm{~cm}$ do solo, foi contado o número de plantas e de espigas nas duas linhas centrais. Após o corte, todas as plantas da mesma linha foram agrupadas, identificadas e conduzidas até o laboratório, onde o conjunto de plantas da mesma linha foi pesado para a determinação de massa verde e em seguida foi realizada uma amostragem de 8 plantas inteiras ao acaso.

Depois de se medir a altura de cada uma das plantas amostradas, foi realizada a separação em haste, folhas, brácteas e espigas. Cada fração foi pesada separadamente e picada em picadeira em pedaços que variaram de 5 a $12 \mathrm{~cm}$ de comprimento, com a finalidade de homogeneização.

Após a homogeneização, foi retirada uma amostra chamada "planta inteira", que consistia na retirada de uma alíquota do balaio na qual a planta de milho inteira havia 
sido triturada, e também uma amostra chamada "haste", onde somente foram amostradas as partes haste, folhas e brácteas, do conjunto de plantas.

Estas duas amostras, planta inteira e haste de cada parcela, foram embaladas em sacos de papel, separadamente, pesadas e levadas para a estufa de ventilação forçada, 60 a $65^{\circ} \mathrm{C}$ por 48 horas no mínimo.

Todas as amostras secas foram pesadas novamente e agrupadas em sacos plásticos pretos e armazenadas para posterior moagem. Neste intervalo de tempo ocorreu um ataque de caruncho e de ratos principalmente na fração haste da base de Piracicaba levando à eliminação de algumas amostras da planta inteira e de todas as amostras da haste desta base devido à alteração da amostra em conseqüência do ocorrido.

Como etapa seguinte, foi realizada a moagem de todas as amostras em um moinho tipo Willey com peneira de $1 \mathrm{~mm}$. As amostras moídas foram acondicionadas em sacos plásticos e identificadas para posterior utilização nas determinações bromatológicas.

\subsection{Determinações Bromatológicas}

As determinações bromatológicas executadas foram: porcentagem de matéria seca $(\mathrm{MS} \%)$; proteína bruta (PB); extrato etéreo (EE); matéria mineral (MM); fibra em detergente neutro (FDN); Fibra em detergente ácido (FDA), Digestibilidade verdadeira “in vitro" da MS e amido.

As amostras, primeiramente, foram analisadas no NIRS (Barton,1989; Templeton et al., 1983) coletando-se o espectro de todas elas. Após a coleta dos espectros, o NIRS determinou quais amostras eram redundantes, isto é, as que possuíam o espectro semelhante, e quais deveriam ser analisadas pela metodologia convencional com a finalidade de melhorar a curva de cálculo de todo o material coletado e assim conseguir valores mais precisos. Nas amostras indicadas pelo NIRS, primeiramente foram 
realizadas as análises de matéria seca, conduzidas em duplicatas conforme metodologia descrita pela AOAC (1980).

As mesmas amostras também foram analisadas para as frações fibra em detergente neutro (FDN) e amido. O FDN foi analisado, em duplicatas, de forma seqüencial, conforme metodologia descrita por Van Soest et al. (1991), utilizando-se do equipamento Fiber Analyser Ankom 200 (Holden, 1999). Já a determinação do amido foi realizada em triplicata, através da técnica descrita por Poore et al. (1989).

\subsection{Determinação da Degradabilidade "in situ"}

A determinação da degradabilidade "in situ" foi realizada para as amostras selecionadas pelo NIRS englobando tanto as representadas pela parte "haste" como as de "planta inteira".

As sacolas foram confeccionadas em náilon monofilamentoso com abertura de poro de aproximadamente $50 \mu$ e com dimensões de 7 x $15 \mathrm{~cm}$. Para as determinações de FDN as sacolas continham 4,0 g de amostra, e para as de amido as sacolas possuíam 5,0

$\mathrm{g}$ de amostra, correspondendo assim a uma relação média de $20 \mathrm{mg} \mathrm{cm}^{-2}$. O fechamento das bordas foi feito através de solda obtida com o uso de resistência elétrica.

O animal utilizado no ensaio foi uma vaca da raça holandesa com 161 dias em lactação, canulada no rúmen e com peso aproximado de $600 \mathrm{~kg}$ de $\mathrm{PV}$, pertencente ao Departamento de Produção Animal da ESALQ/USP.

A dieta fornecida ao animal consistia de silagem de milho (teor de MS de 29\%) como volumoso mais concentrado, cujos principais componentes do concentrado eram: milho moído fino (16\%), polpa cítrica (16\%), farelo de soja (10\%), farelo de algodão (10\%), uréia $(1 \%)$, bicarbonato de soja e minerais $(3,5 \%)$ e óleo vegetal (resíduo de restaurante - 2\%). A relação volumoso:concentrado na ração completa era de 40:60 (\% na MS) mais minerais. 
A dieta foi fornecida a vontade de modo a manter-se sobra aproximada de 5 a $10 \%$ do fornecido. A composição química da dieta utilizada pelo animal consistia de 17,5\% de PB, 29,4\% de FDN, 20,0\% de FDA, 45,6\% de carboidratos não fibrosos e 3,1\% de EE mais Ca e P na relação 1,2:0,5.

Durante o período de incubação o animal manteve consumo médio de $21 \mathrm{~kg}$ de MS de ração completa (concentrado + volumoso) e produção média de 40,2 L de leite.

Antes da incubação ruminal, as sacolas de náilon contendo as amostras, foram enxaguadas em água morna por 10 minutos, para remover a fração solúvel e diminuir o tempo de colonização das partículas pelos microrganismos ruminais (Silva, 1997). As sacolas foram incubadas no animal sempre no mesmo horário (11:30h) e retiradas após o tempo determinado. As sacolas foram agrupadas em uma argola com ganchos de metal e amarradas a uma corrente com peso suficiente para mantê-los imersos no rúmen. Com a finalidade de evitara perda das sacolas no rúmen, devido a sua movimentação do mesmo, foi presa à corrente uma corda de náilon de $50 \mathrm{~cm}$ de comprimento. As sacolas foram incubadas em duas etapas. A primeira foi realizada com as sacolas das amostras de planta inteira, que permaneceram por $72 \mathrm{~h}$ no rúmen, após a retirada destas, foi realizada a segunda etapa com as sacolas das amostras de haste e de planta toda que permaneceram durante um período de $144 \mathrm{~h}$. O tempo de incubação de $72 \mathrm{~h}$ foi utilizado para a determinação da degradabilidade do amido, já o de 144h para as determinações de FDN degradável.

Após serem retiradas do rúmen, as sacolas foram imediatamente colocadas em água gelada para paralisação do processo de degradação e, em seguida, lavadas em um tambor com agitação e fluxo de água constante, sendo que a água foi renovada até a mesma se apresentar transparente. Depois disso as sacolas foram colocadas em estufa a $65^{\circ} \mathrm{C}$ durante $48 \mathrm{~h}$ e o peso registrado para determinação da MS do resíduo, sendo que este foi analisado tanto para FDN (Van Soest et al., 1991) como para amido (Poore et al., 1989).

A determinação das degradabilidades foi obtida pela diferença entre as quantidades de amostra incubadas e o resíduo após incubação. 
Após análise química, estes valores foram inseridos no NIRS com a finalidade de melhorar a acurácia da curva de predição de cada um dos parâmetros utilizados neste estudo. Após esta etapa, todos os parâmetros necessários neste estudo foram estimados pelo NIRS: porcentagem de matéria seca (MS\%); proteína bruta (PB); extrato etéreo $(\mathrm{EE})$; matéria mineral (MM); fibra em detergente neutro (FDN); Fibra em detergente ácido (FDA), Digestibilidade verdadeira "in vitro" da MS e amido, para todas as amostras do experimento.

\subsection{Estimativas de produção de leite por tonelada de MS de forragem e por hectare}

A planilha do Microsoft Excel denominada Milk 2000 (Schwab et al., 2001) foi utilizada para a realização da estimativa de produção de leite por ton de MS de forragem e por ha a partir dos dados de produção de MS, e dos teores de MS, PB, FDN, digestibilidade do FDN, amido, digestibilidade do amido, EE, MM das amostras de planta inteira dos cultivares em cada localidade.

A Milk2000 tem como base a planilha Milk 95 com algumas mudanças, tais como, a inclusão da digestibilidade das porções amido e FDN na equação que determina a energia líquida da dieta. Nesta planilha o conteúdo de energia da silagem de milho é estimado usando uma modificação da equação somatória de Weiss et al. (1998). Nesta equação somatória modificada, PB, EE, FDN, amido e açucares são incluídos junto com seus respectivos coeficientes de digestibilidade para estimar a quantidade de energia da silagem de milho.

Os valores encontrados através do NIRS para cada cultivar, em cada localidade, serão utilizados para a determinação da produção de leite por tonelada de forragem e por hectare utilizando-se a planilha Milk 2000. Os resultados encontrados nesta planilha serão plotados, produção de leite por hectare no eixo X e produção de leite por tonelada de forragem no eixo Y, em um gráfico de dispersão para cada local deste estudo para posterior analise de qualidade dos cultivares. 


\subsection{Delineamento experimental e análise estatística}

O delineamento experimental utilizado foi $\mathrm{o}$ de blocos casualizados com 4 repetições e 20 tratamentos por bloco para as análises das características químicas e agronômicas das frações haste e planta toda em cada local. O esquema de análise de variância e o modelo utilizado para cada local seguem na Tabela 5.

Tabela 5. Análise de variância do experimento dentro de um local

\begin{tabular}{lc}
\hline Causas de Variação & Graus de Liberdade \\
\hline Tratamento & 19 \\
Bloco & 57 \\
Resíduo & 79 \\
Total & \\
\hline Modelo: $\mathrm{Y}_{\mathrm{ij}}=\mathrm{m}+\mathrm{th}_{\mathrm{i}}+\mathrm{b}_{\mathrm{j}}+\mathrm{e}_{\mathrm{ij}}$ & onde, $\mathrm{m}=$ média geral; th= híbrido; B= bloco; \\
e= efeito residual &
\end{tabular}

Para a comparação das características agronômicas entre locais o delineamento experimental foi em blocos (4 blocos), no esquema fatorial $20 \times 4$ (20 híbridos e 4 locais). O esquema de análise de variância e o modelo utilizado para interação local X híbrido seguem na Tabela 6.

Os resultados obtidos dos testes de variância e as médias foram comparados pelo teste de Tukey a $5 \%$ de probabilidade, sendo também determinados os coeficientes de correlação linear de Pearson. 
A análise estatística foi realizada utilizando-se o pacote estatístico SAS (1999). Antes do início das análises, todas as variáveis foram testadas quanto à sua normalidade e homogeneidade da variância.

Com o objetivo de determinar a correlação entre as variáveis estudadas, tanto da porção planta inteira como haste, utilizou-se o procedimento de análise de correlação de Pearson. Para isto, também foi utilizado o pacote estatístico SAS (1999).

Os valores médios das porcentagens da fração grão na MS da planta versus os coeficientes de DVIVMS da planta inteira, assim como as estimativas de produção de leite por ton de forragem versus as estimativas de produção de leite por ha, foram representados graficamente por meio de diagramas de dispersão para os diferentes locais onde o experimento foi desenvolvido.

Tabela 6. Análise de variância do experimento da interação local x híbrido

\begin{tabular}{lc}
\hline Causas de Variação & Graus de Liberdade \\
\hline Híbridos & 19 \\
Bloco & 3 \\
Local & 3 \\
Local x Híbrido & 57 \\
Resíduo & 237 \\
Total & 319 \\
\hline
\end{tabular}

Modelo: $\mathrm{Y}_{\mathrm{ijk}}=\mathrm{m}+\mathrm{th}_{\mathrm{i}}+\mathrm{b}_{\mathrm{j}}+\mathrm{l}_{\mathrm{k}}+\mathrm{e}_{\mathrm{ijk}}$ onde, $\mathrm{m}=$ média geral; th= híbrido; $\mathrm{b}=$ bloco; $1=$ local; $\mathrm{e}=$ efeito residual 
Os resultados da análise de variância dos blocos não foram apresentados no item resultados e discussão, devido ao bloco ser utilizado para controle local, não se discutindo seus efeitos. 


\section{RESULTADOS E DISCUSSÃO}

\subsection{Características Agronômicas}

\subsubsection{Produções de Matéria Seca, Massa Verde e População}

Os resultados médios da produção de grãos, produção de matéria seca (PMS), produção de massa verde (PMV) e população de plantas dos vinte cultivares nos quatro locais estão apresentados na Tabela 7.

A produção de grãos, o teor de MS e a população de plantas por hectare não foram diferentes $(\mathrm{P}<0,05)$ entre os vinte cultivares nos quatro locais. Entretanto, verifica-se diferença quantitativa de $2684 \mathrm{~kg} \mathrm{ha}^{-1}$ entre o cultivar AG 4051 de maior produção e o cultivar IAC Vitória de menor produção que deve ser levada em conta. A produção média de grãos dos vinte cultivares foi de $6.937 \mathrm{~kg} \mathrm{ha}^{-1}$, valor bem próximo ao encontrado por Henrique et al. (1997) que avaliaram vários cultivares e obtiveram a média de $7.208 \mathrm{~kg} \mathrm{ha}^{-1}$. Entretanto, quando se observa as médias de cada local verificase que, Mococa e Votuporanga foram as cidades que mais se destacaram na produção de grãos com 7.351 e $6.856 \mathrm{~kg} \mathrm{ha}^{-1}$, respectivamente. Já em relação à população nos quatro locais, Mococa foi a que apresentou menor valor médio,com 53.216 plantas por hectare, em razão do maior espaçamento utilizado nesta localidade (Tabela 7). 
Tabela 7. Produção de grãos, massa verde e matéria seca, porcentagem de MS e população dos cultivares de milho

\begin{tabular}{|c|c|c|c|c|c|c|}
\hline & & $P G$ & PMV & PMS & MS & População \\
\hline \multirow{13}{*}{ Cultivar: } & AG 4051 & 8.392 & $51.021^{\text {cdef }}$ & $22.746^{\mathrm{a}}$ & 42,95 & 54.759 \\
\hline & P $30 F 44$ & 7.260 & $53.495^{\text {abcde }}$ & $19.827^{\mathrm{ab}}$ & 38,27 & 57.075 \\
\hline & AG 8080 & 8.060 & $53.114^{\text {abcdef }}$ & $22.126^{\mathrm{a}}$ & 41,92 & 55.045 \\
\hline & AGN 2012 & 6.613 & $51.683^{\text {cdef }}$ & $19.453^{a b}$ & 38,45 & 56.162 \\
\hline & A 3663 & 6.567 & $55.909^{\text {abcd }}$ & $20.868^{a b}$ & 39,32 & 54.057 \\
\hline & Tork & 7.289 & $51.693^{\text {cdef }}$ & $20.768^{a b}$ & 40,45 & 56.440 \\
\hline & P30F80 & 6.848 & $53.943^{\text {abcd }}$ & $20.236^{\mathrm{ab}}$ & 38,37 & 55.509 \\
\hline & Z8550 & 6.875 & $51.934^{\mathrm{cdef}}$ & $19.145^{\mathrm{ab}}$ & 37,15 & 56.738 \\
\hline & Traktor & 6.770 & $53.377^{\text {abcde }}$ & $19.993^{\mathrm{ab}}$ & 38,37 & 57.028 \\
\hline & P 3041 & 6.988 & $56.868^{a b}$ & $20.387^{\mathrm{ab}}$ & 35,75 & 56.695 \\
\hline & DAS $112 \mathrm{X}$ & 6.741 & $46.011^{\text {ef }}$ & $19.394^{\mathrm{ab}}$ & 41,77 & 55.478 \\
\hline & Z 8480 & 7.456 & $51.859^{\text {cdef }}$ & $20.679^{a b}$ & 40,20 & 57.035 \\
\hline & IAC Vitória & 5.708 & $43.585^{f}$ & $16.987^{\mathrm{b}}$ & 40,55 & 56.149 \\
\hline Média & & 6.937 & 52.909 & 20.255 & 38,88 & 56.064 \\
\hline $\mathrm{CV}(\%)$ & & 12,89 & 6,88 & 7,87 & 9,38 & 2,48 \\
\hline Médias por & Tarumã & $6.603^{b}$ & $52.544^{b}$ & $17.834^{b}$ & $33,97^{\mathrm{b}}$ & $57.140^{a}$ \\
\hline \multirow[t]{3}{*}{ Local: } & Mococa & $7.351^{\mathrm{a}}$ & $50.234^{b}$ & $21.771^{\mathrm{a}}$ & $43,47^{\mathrm{a}}$ & $53.216^{b}$ \\
\hline & Piracicaba & -- & $45.766^{\mathrm{c}}$ & $20.549^{a}$ & $44,43^{\mathrm{a}}$ & $56.489^{\mathrm{a}}$ \\
\hline & Votuporanga & $6.856^{\mathrm{ab}}$ & $63.255^{\mathrm{a}}$ & $21.200^{\mathrm{a}}$ & $33,64^{b}$ & $57.409^{\mathrm{a}}$ \\
\hline
\end{tabular}

Médias, na coluna, seguidas de letras diferentes, diferem entre si $(\mathrm{P}<0,05)$ pelo Teste de Tukey

$\mathrm{CV}=$ coeficiente de variação

PG = produção de grãos; PMV = produção de massa verde; PMS = produção de matéria seca 
As produções de matéria seca (PMS) e massa verde (PMV) de forragem por hectare foram significativamente diferentes $(\mathrm{P}<0,05)$ para alguns híbridos analisados, com médias de $20.255 \mathrm{~kg} \mathrm{ha}^{-1}$ e $52.909 \mathrm{~kg} \mathrm{ha}^{-1}$, respectivamente (Tabela 7). Para a PMS, os maiores destaques foram os híbridos C333B, Dina 1000, AG 1051 e o AG 8080 com produções de 22.953, 22.774, 22.746, $22.126 \mathrm{~kg} \mathrm{ha}^{-1}$, respectivamente. Em termos de localidade, a cidade de Mococa apresentou diferença significativa $(\mathrm{P}<0,05)$ em relação a cidade de Tarumã com produções de 21.771 e $17.834 \mathrm{~kg} \mathrm{ha}^{-1}$, respectivamente. Almeida (2000) obteve produções médias de MS de 16.830 e $18.400 \mathrm{~kg} \mathrm{ha}^{-1}$ para populações de 55.000 e 60.000 plantas por hectare, respectivamente, o que está próximo dos valores obtidos nos diversos cultivares deste trabalho. Entretanto, Penati (1995) e Almeida Filho et al. (1999) obtiveram produções médias de $13.410 \mathrm{~kg} \mathrm{ha}^{-1}$ e $12.600 \mathrm{~kg} \mathrm{ha}^{-1}$ respectivamente, sendo que o primeiro autor avaliou vinte e o segundo nove cultivares. Quando se considera a produção de MS de certos cultivares, Silva (1997) encontrou para o ano de 1997 produções de $20.870 \mathrm{~kg} \mathrm{ha}^{-1}$ e $21.824 \mathrm{~kg} \mathrm{ha}^{-1}$ para os cultivares AG 4051 e C333B o que se mostraram próximos dos valores encontrados neste trabalho.

As diferenças nas condições de solo e clima predominantes nos diversos locais em que os experimentos foram desenvolvidos, assim como nos teores de adubação e nas práticas de manejo utilizadas foram fatores preponderantes nos resultados de produções de forragem. Nesse trabalho as boas condições de fertilidade (V\% alta, teor de fósforo adequados, soma de bases balanceada), a adubação adequada, além das boas condições climáticas, durante o período experimental, permitiram que os híbridos testados pudessem expressar o seu máximo potencial de desenvolvimento, com exceção dos cultivares avaliados em Piracicaba, onde ocorreu alguns veranicos (Apêndice 1), o que resultou em perdas no seu desenvolvimento em relação aos cultivares avaliados nos outros locais.

Quanto à PMV, a maior produção numérica foi encontrada no cultivar Dina 1000 com produção de $62.743 \mathrm{~kg} \mathrm{ha}^{-1}$, embora numérica diferenças de até $15 \%$ foram encontradas entre os cultivares, exemplo disso é a diferença entre os cultivares Dina 1000 e AG 8080. Já entre locais o maior destaque foi Votuporanga, que apresentou a 
maior média $\left(63.255 \mathrm{~kg} \mathrm{ha}^{-1}\right)$ quando comparada com as demais cidades $(\mathrm{P}<0,05)$. Quando se compara esses valores com os observados por dos Santos et al. (2002), que obtiveram produções médias de $45.123 \mathrm{~kg} \mathrm{ha}^{-1}$ ao avaliarem 12 cultivares no Paraná, observa-se que os valores do presente estudo foram superiores. Ao se observar somente um dos cultivares avaliados, por exemplo, o Tork, nota-se que nesse estudo a produção de massa verde foi de $51.693 \mathrm{~kg} \mathrm{ha}^{-1}$ enquanto no estudo realizado por Santos et al. (2002) o valor foi de $46.445 \mathrm{~kg} \mathrm{ha}^{-1}$, o que evidencia que a diferença também é mantida em termos de cultivar. Estas variações na PMV estão diretamente relacionadas aos mesmos fatores que afetam a PMS e portanto já esclarecidos anteriormente.

No tocante ao teor de MS, não houve diferença entre os cultivares, mas em termos de local, ocorreu diferença $(\mathrm{P}<0,05)$ entre Piracicaba e Mococa em relação a Tarumã e Votuporanga, onde nas duas primeiras localidades as médias ficaram em 44,43 e $43,47 \%$, respectivamente.

Para a colheita das plantas de milho foi adotado como critério o acompanhamento da linha de leite, que é definida como o limite entre o endosperma solidificado (amarelo) e o endosperma líquido (esbranquiçado). A colheita, portanto, foi realizada quando a linha de leite estivesse entre 1/3 e 2/3, a partir do topo do grão em direção à sua inserção no sabugo, o que deveria resultar em teores de MS entre 30 e $35 \%$ para as plantas colhidas na altura de corte baixa $(5 \mathrm{~cm})$ conforme preconizado por Nussio \& Manzano (1999). O teor de MS dos grãos (Apêndice 2) comprova que nas cidades de Piracicaba e Mococa o milho foi colhido em época semelhante e avançada em maturidade em relação às cidades de Tarumã e Votuporanga, apesar do mesmo critério ter sido utilizado.

Sulc et al. (1996) observaram que o critério da linha de leite foi bom indicador, na média, do momento de colheita de plantas de milho para ensilagem, entretanto, esses autores também demonstraram que ocorreu considerável variação no teor de MS da planta inteira em um mesmo estádio de linha do leite e concluíram que o método deve ser ratificado através da determinação do teor de MS da planta para confirmar o ponto ótimo de colheita. Nussio et al. (2000) também observaram que a linha de leite é bom indicador para a determinação da umidade da planta de milho, porém, o método pode 
induzir a erros sob condições de veranico, déficit hídrico, presença de stay green e características especiais dependentes de cultivares, pois nesses casos, a correlação entre evolução na linha de leite, maturidade fisiológica das plantas e o teor de MS poderá ser muito baixa. Costa (2000) observou que os teores de matéria seca de plantas de milho para ensilagem variaram entre 35 e $44 \%$, quando estas foram colhidas no estágio de 3/4 de linha de leite.

Segundo Fancelli et al. (2000) o corte efetuado com teores de matéria seca acima de $37 \%$, não é recomendável, pois as folhas encontram-se mais secas acarretando maiores perdas durante o corte, além do fato de dificultar a compactação e a eliminação do ar da massa do silo. No mesmo sentido Nussio (1990) relatou que quando as plantas são colhidas com teor de MS acima de 38\%, há a possibilidade de resultados positivos quanto à produção de matéria seca por hectare; entretanto, as perdas no campo são aumentadas (perda de folhas) e além disso se for considerado o uso de silo de trincheira convencional, as dificuldades de compactação podem comprometer a qualidade da silagem produzida, devido à aeração do silo, não se conseguindo assim obter a densidade ideal de 500 a $600 \mathrm{Kg} \mathrm{m}^{-3}$ para eliminar todo o ar contido na massa. Enfatizando esse aspecto, Tarumã e Votuporanga apresentaram cultivares de planta de milho com teores ideais de MS para a ensilagem; entretanto, Piracicaba e Mococa apresentaram plantas com teores acima do ideal (em torno de 43\%) o que compromete a compactação adequada no momento da ensilagem, além de aumentar a probabilidade de perdas de folhas, que apresentam alta digestibilidade.

\subsubsection{Composição das partes da planta}

A variação percentual dos componentes da planta encontram-se na Tabela 8 . A \% de grãos (GPT), a \% de grãos na espiga (Gesp) além da fração folhas não apresentaram diferenças $(\mathrm{P}>0,05)$. Em termos de local, estas mesmas características foram diferentes $(\mathrm{P}<0,05)$ sendo que a cidade que apresentou a maior porcentagem de GPT e GE em relação à planta toda foi Mococa $(39,16 \%$ e 64,32\%) em relação a Votuporanga 32,43\% e $59,93 \%)$. 
Tabela 8. Frações da planta de milho nas cidades de Tarumã, Mococa, Piracicaba e Votuporanga

\begin{tabular}{|c|c|c|c|c|c|c|}
\hline & & GPT & Gesp & $\mathrm{H} / \mathrm{P}$ & $\mathrm{F} / \mathrm{P}$ & $\mathrm{E} / \mathrm{P}$ \\
\hline & & |--------- & --------- & ------------- & $-\mathrm{g} \mathrm{kg} \mathrm{M}$ & \\
\hline \multirow{20}{*}{ Cultivar } & Dina 1000 & 33,83 & 58,80 & $27,90^{\mathrm{abcd}}$ & 18,60 & $53,47^{\mathrm{ab}}$ \\
\hline & AG 4051 & 39,10 & 70,93 & $28,45^{\mathrm{abcd}}$ & 15,50 & $56,62^{a b}$ \\
\hline & C 333B & 32,16 & 59,86 & $29,80^{\mathrm{ab}}$ & 17,90 & $51,30^{\mathrm{b}}$ \\
\hline & P 30F44 & 37,26 & 66,53 & $23,97^{\mathrm{cde}}$ & 18,17 & $57,57^{\mathrm{ab}}$ \\
\hline & AG 8080 & 39,10 & 65,43 & $26,37^{\text {bdce }}$ & 17,75 & $56,47^{\mathrm{ab}}$ \\
\hline & CATI AL30 & 33,56 & 61,20 & $32,25^{\mathrm{a}}$ & 17,87 & $51,22^{b}$ \\
\hline & C 7474 & 33,10 & 59,66 & $26,85^{\text {bcde }}$ & 18,62 & $55,27^{\mathrm{ab}}$ \\
\hline & AGN 2012 & 35,13 & 61,30 & $26,07^{\text {bcde }}$ & 18,37 & $54,82^{\mathrm{ab}}$ \\
\hline & А 3663 & 31,13 & 57,50 & $30,17^{\mathrm{ab}}$ & 16,65 & $53,12^{\mathrm{ab}}$ \\
\hline & Tork & 35,70 & 63,50 & $26,77^{\text {bcde }}$ & 17,30 & $56,22^{\mathrm{ab}}$ \\
\hline & P30F80 & 35,34 & 60,00 & $26,26^{\text {bcde }}$ & 15,36 & $57,94^{\mathrm{ab}}$ \\
\hline & Z8550 & 41,46 & 59,73 & $24,20^{\mathrm{cde}}$ & 18,17 & $58,27^{\mathrm{ab}}$ \\
\hline & AGN 3060 & 33,90 & 60,96 & $28,12^{\mathrm{abcd}}$ & 16,75 & $55,75^{\mathrm{ab}}$ \\
\hline & Graúna 183 & 36,23 & 60,06 & $27,75^{\text {abcd }}$ & 18,60 & $54,95^{\mathrm{ab}}$ \\
\hline & Z 8420 & 38,00 & 62,46 & $22,22^{\mathrm{e}}$ & 16,95 & $61,55^{\mathrm{a}}$ \\
\hline & Traktor & 36,10 & 66,30 & $27,92^{\text {abcd }}$ & 18,20 & $53,95^{\mathrm{ab}}$ \\
\hline & P 3041 & 35,93 & 64,93 & $28,57^{\mathrm{abc}}$ & 15,97 & $56,20^{\mathrm{ab}}$ \\
\hline & DAS $112 \mathrm{X}$ & 36,43 & 60,40 & $29,27^{\mathrm{abc}}$ & 17,30 & $53,75^{\mathrm{ab}}$ \\
\hline & Z 8480 & 37,43 & 63,73 & $23,15^{\mathrm{de}}$ & 18,92 & $58,72^{a b}$ \\
\hline & IAC Vitória & 32,96 & 60,63 & $32,50^{\mathrm{a}}$ & 18,10 & $50,45^{b}$ \\
\hline Média & & 35.69 & 62,44 & 27,42 & 17,52 & 55,38 \\
\hline CV (\%) & & 14,26 & 7,10 & 7,41 & 17,67 & 5,84 \\
\hline Médias por & Tarumã & $35,43^{a b}$ & $62,42^{\mathrm{ab}}$ & $31,94^{\mathrm{a}}$ & $15,69^{\mathrm{bc}}$ & $53,64^{b}$ \\
\hline \multirow[t]{3}{*}{ Local: } & Mococa & $39,16^{\mathrm{a}}$ & $64,32^{\mathrm{a}}$ & $30,64^{\mathrm{a}}$ & $17,20^{b}$ & $52,16^{\mathrm{b}}$ \\
\hline & Piracicaba & -- & -- & $23,70^{\mathrm{b}}$ & $14,40^{\mathrm{c}}$ & $61,90^{\mathrm{a}}$ \\
\hline & Votuporanga & $32,43^{b}$ & $59,93^{b}$ & $23,39^{b}$ & $22,79^{\mathrm{a}}$ & $53,82^{b}$ \\
\hline
\end{tabular}

Médias, na coluna, seguidas de letras diferentes, diferem entre si $(\mathrm{P}<0,05)$ pelo Teste de Tukey $; \mathrm{CV}=$ coeficiente de variação

GPT = grãos na planta; GEsp = grãos na espiga; $\mathrm{MS}=$ matéria seca; $\mathrm{H} / \mathrm{P}=$ haste/planta; $\mathrm{F} / \mathrm{P}=$ folha/planta; $\mathrm{E} / \mathrm{P}=\mathrm{espiga} / \mathrm{planta}$ 
Quanto à GTP e Gesp, este trabalho obteve média de 35,69\% e 62,44\%, respectivamente para os 20 cultivares analisados nos quatro locais, com diferença numérica na porcentagem de grãos de $10 \%$ entre os cultivares de maior e menor produção, o que parece ser relevante.

Para a GPT, Nussio et al. (2001) em avaliação de três anos consecutivos observaram média de $37,4 \%$ o que está bem próxima da encontrada neste trabalho, enquanto Hunter et al. (1993) encontraram valores um pouco superiores, de 41 e 44\%, quando avaliaram dois cultivares nos EUA. Já Nussio \& Manzano (1999) na safra agrícola de 1997/98 avaliando 16 cultivares e Oliveira et al. (1997) trabalhando com 11 cultivares encontraram valores de $28 \%$ e $26 \%$ de grãos respectivamente, o que está abaixo da média encontrada neste trabalho.

Mahanna et al. (1996) trabalhando com seis diferentes híbridos nos EUA, mostraram que a porcentagem de grãos e espigas passaram respectivamente de $32,4 \%$ e $40,9 \%$ com $1 / 3$ da linha de leite para $46,1 \%$ e $54,3 \%$ na maturidade fisiológica completa, significando que a medida que ocorre o aumento progressivo da maturidade fisiológica da planta de milho há também, como conseqüência, o aumento no teor de grãos e espiga com a variação da MS da planta. Talvez a colheita em diferentes estágios de maturidade seja a razão para as variações encontradas entre os diversos trabalhos com relação à porcentagem de grãos na composição da planta co base na MS.

Hoje em dia a porcentagem de grãos na planta tem sido um dos critérios mais amplamente empregados na escolha de cultivares de milho para a produção de silagens, por ela ser o principal responsável na obtenção de elevada produtividade de MS das plantas de milho por hectare, alto valor nutritivo e adequado teor de MS na planta para proporcionar fermentação adequada e redução de perdas por efluentes que podem ocorrer no processo de ensilagem (Caetano, 2001).

No caso da porcentagem de folhas na planta Votuporanga foi o local que se observou o maior valor $(22,79 \%)$, talvez devido à maior produção de massa verde em relação as produções dos outros locais. Isso ocorreu pelo fato das folhas possuírem baixo teor de MS e participarem com menor porcentagem do que haste e grãos na planta. 
Penati (1995) e Caetano (2001) avaliando vinte e onze cultivares de milho, respectivamente, encontraram médias próximas de 13,69\% e 15,15\% respectivamente, de folhas em relação à planta.

As frações haste $(\mathrm{H} / \mathrm{P})$ e espiga $(\mathrm{E} / \mathrm{P})$, representaram mais de $80 \%$ da composição da planta na média dos vinte cultivares, contando que a fração folha observada foi praticamente constante nos híbridos desse estudo (15,36\% a 18,92\%). As médias dos vinte cultivares para as características $\mathrm{H} / \mathrm{P}$ e E/P foram 27,42 e 55,3\%, respectivamente, sendo que os cultivares de maior produção da fração componente haste foram IAC Vitória e CATI AL 30 com 32,5 e 32,25\%, respectivamente. As duas cidades que obtiveram o maior valor para a fração haste foram Tarumã com 31,94\% e Mococa com 30,64\% da planta. Penati (1995) verificou produção média de haste maior que a apresentada nesse trabalho com média de 34\% em relação à planta toda. Esta diferença nas frações que compõem a planta de milho são em função, principalmente, de fatores fenotípicos (clima, adubação, fertilidade do solo, manejo da cultura etc...)

Quanto à E/P o cultivar de maior produção numérica foi o Z 8420 com 61,55\%, e o de menor produção foi o IAC Vitória com 50,45\%. Com relação aos locais, a cidade que mais se destacou foi Piracicaba em comparação com as demais. Almeida Filho (1999) encontrou valores médios de $45 \%$ de espigas, o que esta abaixo dos valores encontrados neste trabalho. A mesma tendência entre cultivares foi observado para o cultivar AG 4051, que apresentou valor de 51,76\% de espigas no referido trabalho e $56,62 \%$ no presente estudo para o mesmo cultivar. Contudo, Caetano (2001) obteve produção média maior com 58,22\% de espigas em 11 cultivares avaliados.

Pode-se concluir, que a posição de muitos agricultores e pesquisadores em escolher híbridos com alta porcentagem de grãos na MS não está incorreta, porém esta escolha deve estar sempre conciliada à contribuição da parte aérea (haste e folhas) que perfaz 50\% da composição da planta e representa grande parte do seu valor nutritivo. 


\subsection{Composição Química}

De acordo com a Tabela 9 pode-se observar que em cada local o nível de significância para a maioria das características químicas da planta foi significativo e, por este motivo optou-se por discutir os parâmetros citados abaixo em cada local.

\subsubsection{Planta Inteira}

Neste tópico analisaram-se as frações químicas da planta de milho de cada localidade e suas respectivas significâncias, correlações entre os tratamentos e relação com parâmetros agronômicos, quando necessário. 
Tabela 9. Nível de significância, média, CV e fontes de variação da análise química e parâmetros agronômicos de cultivares de milho.

\begin{tabular}{|c|c|c|c|c|c|c|c|}
\hline \multirow[b]{2}{*}{ Variáveis } & \multicolumn{4}{|c|}{ Local } & \multirow{2}{*}{ Média } & \multirow{2}{*}{$\mathrm{CV}$} & \multirow{2}{*}{$\begin{array}{l}\text { Fonte de Variação } \\
\text { (Cidade x Híbrido) }\end{array}$} \\
\hline & Mococa & Piracicaba & Tarumã & Votuporanga & & & \\
\hline & \multicolumn{4}{|c|}{ 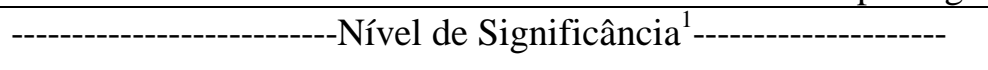 } & & ---- \% ---- & $\operatorname{Pr}>F$ \\
\hline FDNd & $<0,0001$ & $<0,0001$ & 0,0009 & $<0,0001$ & $60,9 \%$ & 1,51 & $<0,0001$ \\
\hline FDN & 0,0008 & $<0,0001$ & 0,0037 & $<0,0001$ & $54,9 \%$ & 5,24 & 0,0019 \\
\hline Amidod & 0,3157 & $<0,0001$ & 0,1579 & $<0,0001$ & $99,96 \%$ & 0,013 & 0,0183 \\
\hline Amido & 0,0014 & $<0,0001$ & 0,0125 & $<0,0001$ & $22,7 \%$ & 14,43 & 0,0009 \\
\hline DIVMS & 0,9972 & 0,0040 & 0,3884 & 0,0016 & $52,0 \%$ & 10,30 & 0,9430 \\
\hline MM & 0,0084 & 0,0254 & 0,0011 & $<0,0001$ & $3,13 \%$ & 19,58 & 0,0727 \\
\hline $\mathrm{EE}$ & $<0,0001$ & 00,0001 & 0,0002 & 0,0008 & $2,05 \%$ & 14,92 & 0,0102 \\
\hline PB & 0,0003 & $<0,0001$ & 0,0624 & 0,0018 & $6,27 \%$ & 13,81 & 0,0303 \\
\hline FDA & 0,0514 & 0,0011 & 0,6593 & $<0,0001$ & $29,3 \%$ & 10,63 & 0,2366 \\
\hline PMS & $<0,0001$ & 00,0001 & 0,0389 & 0,0005 & $19.840 \mathrm{~kg} \mathrm{ha}^{-1}$ & 10,94 & $<0,0001$ \\
\hline PMSD & $<0,0001$ & 0,0004 & 0,0746 & 0,0003 & $10.391 \mathrm{~kg} \mathrm{ha}^{-1}$ & 15,34 & 0,0008 \\
\hline
\end{tabular}

${ }^{\mathrm{I}} \mathrm{P}=$ nível de significância 


\subsubsection{Tarumã}

Através dos dados da Tabela 10 observa-se que a PMS, não apresentou diferença $(\mathrm{P}>0,05)$ entre os cultivares de milho avaliados, no entanto, a diferença numérica foi de $4.397 \mathrm{~kg} \mathrm{ha}^{-1}$, entre os cultivares Z 8550 e AGN 3060.

A produção de matéria seca média em Tarumã foi de $17.830 \mathrm{~kg} \mathrm{ha}^{-1}$, sendo essa menor que a apresentada no Estado de São Paulo (20.255 $\mathrm{kg} \mathrm{ha}^{-1}$ ), em virtude de algum fator climático que interferiu na produção, como veranicos, ou porque esta base recebeu menor adubação em relação às outras, que pode ter afetado a produção neste local.

Para a PMSD a média entre os vinte cultivares ficou em $10.859 \mathrm{~kg} \mathrm{ha}^{-1}$, com maior destaque numérico para o cultivar AGN 2012, que apesar de não ter obtido uma PMS alta, numericamente apresentou mais alta digestibilidade "in vitro" da MS (71\%) (Tabela 10).

Os teores da digestibilidade "in vitro" foram semelhantes entre dezoito dos vinte cultivares avaliados, sendo que o cultivar AGN 2012 só foi significativamente superior $(\mathrm{P}<0,05)$ ao A3663, que apresentou o menor valor (Tabela 10).

A média dos valores de DIVMS dos vinte cultivares ficou ao redor de $60,8 \%$, valor semelhante ao encontrado por Caetano (61,8\%) quando este analisou onze cultivares. Almeida Filho et al. (1999) encontraram valores pouco inferiores, sendo que os cultivares com maior e menor digestibilidades apresentaram valores de 56,86\% e 53,15\%, respectivamente. Entretanto, Penati (1995) e Almeida (2000) encontraram valores superiores aos apresentados nesse trabalho, com médias superiores a $63 \%$ de DIVMS da planta nos diversos cultivares avaliados.

As grandes variações obtidas entre os valores de DIVMS podem ser explicadas pela composição química obtida, conforme pode ser constatado pelo cultivar A 3663 que apresentou os maiores valores numéricos nos teores de FDN e FDA em relação aos demais, além do teor numérico mais baixo de amido $(18,23 \%)$, que é a fração mais digestível da planta (Tabela 11). O cultivar AGN 2012 apresentou um dos menores 
valores numéricos de FDN, valor numérico médio de FDA e o maior teor numérico de amido entre os vinte cultivares, mostrando assim, uma relação direta entre o teor de amido e a DIVMS e indireta entre a FDN e a DIVMS da planta toda.

Os resultados de DIVMS dos cultivares avaliados nesse trabalho mostraram-se inferiores aos resultados obtidos por Thomas et al. (2001) que avaliaram dois híbridos (77,8\% a 80,0\%), com diferentes teores de MS e estádio de desenvolvimento da planta. Já Crasta et al. (1997) e Johnson et al. (1997) e Lundeen (2000) encontraram valores na faixa de 62,2 a 76,8\% de DIVMS, dependendo do estádio fisiológico da planta, época de plantio e tipo de híbrido avaliado, estando esses valores mais próximos dos obtidos nesse estudo. Portanto, pode-se inferir que a DIVMS da planta é superior para os híbridos cultivados nos países de clima temperado, teoricamente devido ao menor teor de FDN e maior teor de amido na planta em conseqüência da sua maior porcentagem de grãos.

Para o extrato etéreo, foi observado teor médio entre os vinte cultivares de 2,23\%, com uma diferença menor que $1 \%$ entre os cultivares com maior (AGN 2012) e menor (Z 8480) valor de EE.

No caso da matéria mineral (MM), também não foram observadas diferenças significativas $(\mathrm{P}>0,05)$, com teor médio entre os vinte cultivares analisados em torno de 4\% (Tabela 10). Russo (1995) ao estudar três diferentes cultivares de milho encontrou valores que variaram de 3,28 a 3,45\% da MS da planta toda, valores inferiores aos obtidos no presente estudo. Nesse sentido Caetano (2001) também encontrou média de $3,45 \%$ de MM, inferior ao valor obtido no presente estudo.

Os teores de amido nos cultivares avaliados na cidade de Tarumã não apresentaram diferença significativa $(\mathrm{P}>0,05)$, cujos resultados variaram de $15,70 \%$ a 23,79\% para os cultivares Cati AL30 e AGN 2012 respectivamente, com média de 20\% (Tabela 11). Os valores apresentados neste experimento ficaram inferiores àqueles encontrados nos estudos desenvolvidos nos EUA, onde o teor de amido variou de 22,2\% a 41,3\% em vários cultivares avaliados em diferentes épocas de colheita (Thomas et al., 
2001; Andrae et al., 2001; Johnson et al., 1999; Kuehn et al., 1996; Lundeen, 2000; Moreira, 2000).

Dentre os fatores de variação apresentados no teor de amido estão a porcentagem de grãos e de haste, que apresentaram relações distintas entre si com relação ao teor de amido, ou seja, quanto maior a porcentagem de grãos maior será o teor de amido e quanto maior a porcentagem de haste menor será esse teor. Outro fator de variação do amido é o teor de MS no momento da colheita, isto é, quanto mais próximo a colheita da maturidade fisiológica da planta de milho menor é o teor de FDN e maior é a porcentagem de amido (efeito diluição). Hunt et al. (1989) ao avaliarem seis diferentes híbridos de milho mostraram que a porcentagem de amido na planta passou de 22,2\% com $1 / 3$ da linha de leite para $31,0 \%$ quando ela atingiu a sua maturidade fisiológica.

O efeito diluição está mais evidente no cultivar Cati AL30. Este cultivar foi o que apresentou o menor valor numérico de amido entre todos os vinte cultivares e ao mesmo tempo o que apresentou o maior valor numérico de FDN na planta.

Com relação ao teor de FDN, constatou-se grande variação entre os vinte cultivares analisados, sendo maior para o cultivar CATI AL 30 e os menores valores para os cultivares DAS 112X, P 30F44 e AGN 2012 (P<0,05) (Tabela 11). Os valores de FDN para a planta $(53,20$ a $62,09 \%)$ situam-se na faixa de 44,7 a $72,11 \%$ obtidas em diversos cultivares de milho no Brasil (Pereira et al., 1997; Almeida filho et al., 1999; Penati, 1995). Nos EUA os cultivares de milho apresentaram valores variando de 42,7 a 48,1\% em trabalhos desenvolvidos por diversos autores (Hunt et al., 1993; Coors, 1996; Russel et al., 1992), demonstrando assim, menores teores de FDN nos cultivares de milho americano. Caetano (2001) constatou que para os cultivares Dina 1000, P 3041 e C333, os teores de FDN foram de 54,66\%, 51,54\% e 53,89\% respectivamente, enquanto que nesse trabalho os valores foram maiores $(55,47,55,17$ e $56,57 \%$, respectivamente) para os mesmos cultivares.

Esse mesmo autor também observou que o teor de FDN, além de ser uma característica própria de cada cultivar milho, pode sofrer influência de vários fatores, como o estádio de desenvolvimento em que a planta é colhida para ensilagem, 
Tabela 10. Parâmetros agronômicos e frações químicas dos cultivares em Tarumã

\begin{tabular}{lllllll}
\hline & & PMS & PMSD & DIVMS & EE & MM \\
\hline \multirow{3}{*}{ Cultivar } & Dina 1000 & 17.803 & $11.501^{\mathrm{ab}}$ & $64,4^{\mathrm{ab}}$ & $2,74^{\mathrm{a}}$ & 4,45 \\
& Tork & 16.385 & $9.858^{\mathrm{ab}}$ & $60,8^{\mathrm{ab}}$ & $2,54^{\mathrm{abc}}$ & 4,07 \\
& Z8550 & 20.474 & $12.044^{\mathrm{ab}}$ & $58,9^{\mathrm{ab}}$ & $2,29^{\mathrm{abc}}$ & 3,51 \\
& AGN 3060 & 16.077 & $9.204^{\mathrm{b}}$ & $57,1^{\mathrm{ab}}$ & $1,97^{\mathrm{bc}}$ & 3,08 \\
& DAS 112X & 15.700 & $9.209^{\mathrm{b}}$ & $59,0^{\mathrm{ab}}$ & $2,07^{\mathrm{abc}}$ & 3,69 \\
& Graúna 183 & 16.477 & $9.725^{\mathrm{ab}}$ & $59,0^{\mathrm{ab}}$ & $2,09^{\mathrm{abc}}$ & 3,74 \\
& Z 8420 & 17.958 & $10.978^{\mathrm{ab}}$ & $61,2^{\mathrm{ab}}$ & $2,19^{\mathrm{abc}}$ & 4,34 \\
& Traktor & 17.246 & $10.597^{\mathrm{ab}}$ & $62,1^{\mathrm{ab}}$ & $2,16^{\mathrm{abc}}$ & 4,38 \\
& P 3041 & 19.272 & $12.057^{\mathrm{ab}}$ & $62,9^{\mathrm{ab}}$ & $2,10^{\mathrm{abc}}$ & 4,70 \\
& AG 4051 & 16.425 & $9.749^{\mathrm{ab}}$ & $59,7^{\mathrm{ab}}$ & $2,18^{\mathrm{abc}}$ & 4,08 \\
& Z 8480 & 18.519 & $11.452^{\mathrm{ab}}$ & $61,0^{\mathrm{ab}}$ & $1,80^{\mathrm{c}}$ & 3,11 \\
& C 333B & 16.696 & $9.707^{\mathrm{ab}}$ & $58,2^{\mathrm{ab}}$ & $2,32^{\mathrm{abc}}$ & 4,00 \\
& P 30F44 & 18.869 & $12.767^{\mathrm{ab}}$ & $68,6^{\mathrm{ab}}$ & $2,61^{\mathrm{ab}}$ & 4,54 \\
& AG 8080 & 16.820 & $10.537^{\mathrm{ab}}$ & $61,6^{\mathrm{ab}}$ & $2,27^{\mathrm{abc}}$ & 3,85 \\
& IAC Vitória & 18.212 & $10.548^{\mathrm{ab}}$ & $58,3^{\mathrm{ab}}$ & $2,13^{\mathrm{abc}}$ & 4,49 \\
& CATI AL30 & 18.864 & $11.593^{\mathrm{ab}}$ & $61,3^{\mathrm{ab}}$ & $2,02^{\mathrm{abc}}$ & 3,74 \\
Cédia & C 747 & 20.283 & $12.298^{\mathrm{ab}}$ & $60,8^{\mathrm{ab}}$ & $1,92^{\mathrm{bc}}$ & 4,51 \\
& AGN 2012 & 19.021 & $13.501^{\mathrm{a}}$ & $71,0^{\mathrm{a}}$ & $2,75^{\mathrm{a}}$ & 4,11 \\
& A 3663 & 18.853 & $10.461^{\mathrm{ab}}$ & $55,3^{\mathrm{b}}$ & $2,21^{\mathrm{abc}}$ & 3,38 \\
& P 30F80 & 16.658 & $9.841^{\mathrm{ab}}$ & $59,0^{\mathrm{ab}}$ & $2,34^{\mathrm{abc}}$ & 4,40 \\
& & 17.830 & $10.859^{-1}$ & 60,8 & 2,23 & 4,00 \\
& & 11.84 & $14.05^{2}$ & 8,79 & 12,61 & 18,77 \\
\hline
\end{tabular}

Médias, na coluna, seguidas de letras diferentes, diferem entre si $(\mathrm{P}<0,05)$ pelo Teste de Tukey.

$\mathrm{CV}=$ coeficiente de variação

$\mathrm{PMS}=$ produção de matéria seca; $\mathrm{PMSD}=$ produção de matéria seca digestível; $\mathrm{EE}=$ extrato etéreo; $\mathrm{MM}=$ matéria mineral; $\mathrm{DIVMS=}$ digestibilidade "in vitro" da MS. 
Tabela 11. Frações químicas dos cultivares em Tarumã

\begin{tabular}{|c|c|c|c|c|c|c|c|}
\hline & & Amido & Amidod & FDN & FDNd & FDA & $\mathrm{PB}$ \\
\hline & & --- & 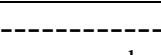 & 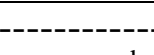 & MS ---.- & $--\cdots$ & ------- \\
\hline \multirow[t]{20}{*}{ Cultivar } & Dina 1000 & 21,86 & $99,96^{\mathrm{ab}}$ & $55,47^{\mathrm{ab}}$ & $61,41^{a b}$ & 29,83 & $8,02^{a b c}$ \\
\hline & Tork & 21,56 & $99,96^{a b}$ & $55,27^{\mathrm{ab}}$ & $61,23^{a b}$ & 29,93 & $8,23^{a b c}$ \\
\hline & Z8550 & 23,02 & $99,96^{\mathrm{ab}}$ & $54,45^{\mathrm{ab}}$ & $61,64^{\mathrm{ab}}$ & 29,30 & $8,00^{a b c}$ \\
\hline & AGN 3060 & 19,74 & $99,95^{\mathrm{ab}}$ & $55,56^{\mathrm{ab}}$ & $62,00^{\mathrm{a}}$ & 29,60 & $8,65^{a b c}$ \\
\hline & DAS $112 \mathrm{X}$ & 22,80 & $99,95^{\mathrm{ab}}$ & $53,46^{\mathrm{b}}$ & $61,38^{a b}$ & 28,19 & $7,97^{a b c}$ \\
\hline & Graúna 183 & 20,06 & $99,95^{\mathrm{ab}}$ & $56,11^{\mathrm{ab}}$ & $62,22^{\mathrm{a}}$ & 29,50 & $9,39^{\mathrm{a}}$ \\
\hline & Z 8420 & 21,19 & $99,96^{a b}$ & $55,68^{a b}$ & $61,45^{a b}$ & 30,04 & $9,13^{\mathrm{ab}}$ \\
\hline & Traktor & 18,36 & $99,95^{\mathrm{ab}}$ & $56,81^{\mathrm{ab}}$ & $61,01^{\mathrm{ab}}$ & 29,91 & $8,17^{a b c}$ \\
\hline & P 3041 & 18,54 & $99,95^{\mathrm{ab}}$ & $55,17^{a b}$ & $61,10^{a b}$ & 30,39 & $9,02^{a b}$ \\
\hline & AG 4051 & 19,54 & $99,96^{\mathrm{ab}}$ & $55,89^{a b}$ & $60,40^{a b}$ & 32,72 & $8,39^{a b c}$ \\
\hline & Z 8480 & 22,55 & $99,95^{\mathrm{ab}}$ & $54,42^{\mathrm{ab}}$ & $61,35^{a b}$ & 29,25 & $8,22^{a b c}$ \\
\hline & C $333 B$ & 18,80 & $99,93^{b}$ & $56,57^{\mathrm{ab}}$ & $61,85^{\mathrm{a}}$ & 30,05 & $8,69^{a b c}$ \\
\hline & P 30F44 & 22,89 & $99,96^{\mathrm{ab}}$ & $53,49^{b}$ & $61,41^{a b}$ & 28,55 & $7,82^{a b c}$ \\
\hline & AG 8080 & 19,95 & $99,96^{\mathrm{ab}}$ & $56,41^{a b}$ & $60,85^{a b}$ & 31,31 & $8,34^{a b c}$ \\
\hline & IAC Vitória & 17,25 & $99,95^{\mathrm{ab}}$ & $58,62^{a b}$ & $60,73^{a b}$ & 32,41 & $8,90^{a b c}$ \\
\hline & CATI AL30 & 15,69 & $99,95^{\mathrm{ab}}$ & $62,09^{\mathrm{a}}$ & $58,81^{\mathrm{b}}$ & 33,60 & $7,39^{b c}$ \\
\hline & C 747 & 16,90 & $99,94^{\mathrm{ab}}$ & $57,70^{a b}$ & $60,46^{a b}$ & 31,64 & $8,57^{\mathrm{abc}}$ \\
\hline & AGN 2012 & 23,79 & $99,97^{\mathrm{a}}$ & $53,20^{b}$ & $60,59^{a b}$ & 30,14 & $7,26^{\mathrm{c}}$ \\
\hline & A 3663 & 18,23 & $99,95^{\mathrm{ab}}$ & $58,69^{a b}$ & $60,94^{a b}$ & 32,20 & $8,08^{a b c}$ \\
\hline & P $30 \mathrm{~F} 80$ & 18,42 & $99,94^{\mathrm{ab}}$ & $58,55^{a b}$ & $61,18^{a b}$ & 31,64 & $8,68^{a b c}$ \\
\hline Média (\%) & & 20,02 & 99,95 & 56,22 & 61,10 & 30,53 & 8,35 \\
\hline $\mathrm{CV}(\%)$ & & 16,80 & 0,011 & 5,36 & 1,76 & 8,93 & 7,96 \\
\hline
\end{tabular}

Médias, na coluna, seguidas de letras diferentes, diferem entre si $(\mathrm{P}<0,05)$ pelo Teste de Tukey.

$\mathrm{CV}=$ coeficiente de variação

Fdn= fibra em detergente neutro; FDA= Fibra detergente ácido; Fdnd= fibra detergente neutro digestível; Amidod= amido digestível; PB=proteína bruta 
e a própria produção de grãos da cultura que ocasionou o efeito diluição na planta de milho com a proximidade do ponto de maturidade fisiológica. O efeito diluição provoca a diminuição do teor de FDN pelo aumento progressivo no teor de amido, decorrente do enchimento de grãos. Crasta et al. (1997) observaram que nesse processo, ocorre a redução do teor de FDN da planta inteira à medida que o ponto de colheita passa do estádio de florescimento para o estádio de $2 / 3$ da linha de leite.

Quanto aos coeficientes de digestibilidade do amido (amidod) e digestibilidade do FDN (FDNd), ambos foram diferentes entre si $(\mathrm{P}<0,05)$ quando avaliados os vinte cultivares, com resultados médios de $99,95 \%$ e $61,10 \%$, respectivamente. Tanto o amidod como o FDNd apresentaram pequena variação, entre 99,93 a 99,97\% para amidod e 58,81 a 61,85\% para FDNd, quando avaliadas nos diferentes cultivares. Tanto o primeiro como o segundo parâmetro apresentaram valores próximos entre os cultivares analisados, em função do tempo de incubação de 72 e 144h, respectivamente, tempo em que se alcança a máxima extensão de digestibilidade.

Caetano (2001) observou digestibilidade da FDN variando entre 36,49\% e $45,74 \%$, com tempo de incubação "in vitro" inferior aos avaliados no presente trabalho. Jung et al. (1998) ao comparar a digestibilidade do FDN de diferentes híbridos mostraram que a extensão potencial da digestão de FDN variou sensivelmente quando as amostras foram analisadas tanto pelo NIRS $(51,6 \%$ a $72,2 \%)$ como no método convencional de análise (48,4 a 72,6\%). Constataram também que a extensão potencial da digestão da FDN foi correlacionada $(r=0,96)$ com o período de 96 horas de incubação.

Andrae et al. (2001) demonstraram que a digestibilidade do amido (amidod) está associada diretamente com a porcentagem de MS, com valores de amidod variando entre $98,0 \%$ a $99,0 \%$ de digestibilidade quando a planta foi incubada durante o período de 96h, e concluiram que o aumento na digestibilidade da MS parece estar relacionado com o aumento na taxa e extensão da digestibilidade do amido. Bal et al. (2000), também constataram que a digestibilidade do amido varia conforme a linha de leite, onde a planta ao passar do estágio de "early dent" (farináceo) para 2/3 da linha de leite (farináceo- 
duro), as digestibilidades aumentaram de 93,8 para 95,6\%, quando a planta de milho foi incubada por $24 \mathrm{~h}$ no rúmen. Philippeau et al. (1997) verificaram que, além da maturidade da planta, a digestibilidade do amido está também relacionada diretamente com a textura do endosperma do grão, ou seja quanto menos vítreo for o material maior será sua digestibilidade.

Com relação à FDA, esta não apresentou diferença significativa entre os cultivares analisados ( $\mathrm{P}>0,05)$, com média de 30,53\% (Tabela 11), com pequena variação entre os cultivares. Caetano (2001) e Almeida (2000) apresentaram valores muito próximos ao encontrado nesse experimento, com valores de $28,63 \%$ e $39,3 \%$, respectivamente. Coors (1997) mostrou que para diferentes teores de grãos (0-100\%) na planta inteira a FDA sofreu redução do seu teor variando de $31 \%$ a $26 \%$, com valor médio ao redor de $28 \%$. Lauer (1996b) mostrou que conforme a maturidade da planta avança, a quantidade de FDA segue o mesmo sentido, com a planta passando de $23 \%$ no ponto de grão pastoso para $32 \%$ de FDA quando o grão atinge seu estado de maturidade fisiológica. Isto mostra que a FDA sofre uma variação conforme a quantidade de grãos aumenta ou diminui na planta em função do seu estágio fisiológico.

Os teores de proteína bruta (PB) variaram de 7,26\% a 9,39\% para os cultivares AGN 2012 e Graúna 183, respectivamente, com valor médio entre os vinte cultivares de 8,35\% de PB (Tabela 11). Pereira et al. (1997) ao avaliarem seis cultivares encontraram valores que variavam de 8,1 até 9,1 , valores que estão na faixa de variação encontrada neste trabalho. Entretanto, Almeida Filho (1999) constatou que em nove cultivares avaliados, os valores de PB variaram de 6,01\% a 8,22\%, ficando em uma faixa de variação inferior a obtida no presente trabalho.

Lavezzo et al. (1997a), observaram que o teor de PB foi menor para plantas colhidas em estádio de desenvolvimento mais avançado, ou seja, os teores de PB diminuem à medida que a planta atinge o seu ponto de maturidade fisiológica. Essa afirmação é comprovada por Lauer (1996b) ao estudar o cultivar P 3921, demonstrando que plantas ao passarem do estágio de grão pastoso para o estádio de maturação fisiológica têm sua proteína bruta diminuída de 10 para $7 \%$ da MS. 
A estimativa de correlações da DIVMS as frações químicas e parâmetros agronômicos estão apresentados nas Tabelas 12 e 13. Os coeficientes de correlação mais relevantes foram obtidos para porcentagem de haste em relação à planta $(r=-0,38)$, para as frações, FDN $(r=-0,60)$ e FDA $(r=-0,47)$, mostrando uma relação inversa com a DIVMS.

Para os coeficientes de correlação da DIVMS com as frações folha $(r=0,33)$, grãos $(r=0,30)$ e espiga $(r=0,37)$, e com os teores de amido $(r=0,42)$, amidod $(r=$ 0,43) e PMSD ( $r=0,61)$, observa-se uma relação direta, ou seja, um aumento desses parâmetros na planta toda levará a um aumento na estimativa da DIVMS. Isso evidencia que a digestibilidade da planta de milho está ligada diretamente e positivamente com as frações folha e grãos, e negativamente correlacionada com a porção haste e com os teores dessa fração. Essas correlações obtidas foram similares às encontradas por Caetano (2001), Crasta et al. (1997) e Johnson et al. (1997).

Os estudos de correlações permitem visualizar (Tabelas 12 e 13) as interações do teor de amido com as frações químicas que representam a haste, no caso a FDN e a FDA, e a fração amido, que representa os grãos e a espiga. Assim, o teor de amido está correlacionado positivamente com a $\%$ de grãos $(r=0,54), \%$ de espigas $(r=0,49)$ e com a DIVMS $(r=0,42)$, FDNd $(r=0,60)$ e Amidod $(r=0,59)$. Para as frações haste, FDN e FDA os estudos mostram uma relação inversamente proporcional com a haste $(\mathrm{r}=$ $0,66)$, o FDN $(r=-0,87)$ e o FDA $(r=-0,80)$.

Os coeficientes de correlação obtidos entre o teor de FDN e FDA (r= -0,79), FDN e a porcentagem de haste $(r=0,60)$ na MS, os coeficientes negativos entre o teor de FDN e a porcentagem de grãos $(r=-0,50)$, FDN e $\%$ de espigas $(r=-0,47)$ na matéria seca da planta, e entre FDN e amido $(r=-0,87)$ (Tabelas 12 e 13) suportam as considerações realizadas anteriormente, onde a FDN possui relação diretamente proporcional com a \% de haste e o teor de FDA e inversamente proporcional com os parâmetros grãos, espiga e amido durante o desenvolvimento da planta de milho. Estas mesmas tendências nas correlações foram encontradas por outros autores em diversos 
híbridos de milho colhidos no mesmo estádio de maturidade (Caetano, 2001; Wolf et al., 1993a; Coors, 1996).

Tabela 12. Correlações entre as principais características agronômicas e frações químicas em Tarumã.

\begin{tabular}{cccccc}
\hline Variáveis & DPT & Amido & FDN & FDNd & Amidod \\
\hline G & 0,296 & $0,536^{*}$ & $-0,503^{*}$ & 0,170 & $0,563^{*}$ \\
MS & 0,260 & 0,380 & $-0,172$ & $-0,330$ & 0,298 \\
HP & $-0,375$ & $-0,658^{*}$ & $0,603 *$ & $-0,404$ & $-0,455$ \\
FP & 0,328 & 0,244 & $-0,151$ & 0,059 & 0,198 \\
EP & 0,372 & $0,487^{*}$ & $-0,469$ & 0,323 & $0,541^{*}$ \\
\hline
\end{tabular}

* Significativo a $5 \%$ pelo teste de correlação de Pearson.

$\mathrm{G}=$ grãos; $\mathrm{MS}=$ matéria seca; $\mathrm{H} / \mathrm{P}=$ haste/planta; $\mathrm{F} / \mathrm{P}=$ folha/ planta; $\mathrm{E} / \mathrm{P}=$ espiga/planta; DPT = digestibilidade da planta toda; FDN = fibra em detergente neutro; FDA = fibra em detergente ácido; Amidod = amido digestível; FDNd= fibra em detergente neutro digestível

Com relação aos coeficientes de correlação entre o FDNd e os principais parâmetros das frações que compõem a planta, observou-se que este está positivamente correlacionado com a porcentagens de grãos $(r=0,17)$ e de espiga $(r=0,32)$ Entretanto, para as correlações do FDNd com a quantidade de haste e a com porcentagem de matéria seca $(r=-0,33$ para ambas) a relação foi inversa (Tabela 12). Isto indica que quanto mais haste a planta possuir menor será a digestibilidade da FDN e vice-versa. Com o avanço da maturidade fisiológica da planta e concomitante aumento do teor de MS, mais lignificada fica a haste e como resultado, menor será a digestibilidade da FDN, tornando a planta mais indigestível (Givens \& Deaville, 2001).

Para as frações químicas as correlações (Tabela 13) também mostraram relação positiva entre o FDNd e os parâmetros DIVMS da planta $(\mathrm{r}=0,39)$ e teor de amido $(\mathrm{r}=$ 0,60). Já entre o FDNd e as frações FDN $(r=-0,64)$ e FDA $(r=-0,69)$, as principais frações da haste, as correlações foram negativas complementando assim as proposições 
feitas no parágrafo anterior. Dessa forma, cultivares de milho com elevada digestibilidade da FDN deverão apresentar maior digestibilidade da MS da planta. Essa é uma característica importante a ser considerada na escolha de cultivares de milho para a produção de silagem, demonstrando assim que a qualidade da haste é importante fator que interfere na qualidade nutricional da planta.

Os coeficientes de correlação demonstraram que a digestibilidade do amido, no caso dos resultados obtidos na cidade de Tarumã, correlacionou-se positivamente com o teor de grãos $(r=0,56)$ e com o teor de MS $(r=0,30)$ e negativamente com a quantidade de haste $(r=-0,45)$ na planta. Quanto à fração química, o amidod correlacionou-se positivamente com a digestibilidade da planta $(r=0,43)$, com o teor de amido $(r=0,59)$, e negativamente com as frações que representaram a parede celular, FDN $(r=-0,43)$ e FDA $(r=-0,30)$. Os resultados indicam que a digestibilidade do amido tem relevância na estimativa da digestibilidade da planta, e conseqüentemente torna-se mais um parâmetro importante ser considerado no momento da escolha de um cultivar de milho para produção de silagem.

Quanto aos coeficientes de correlação entre o teor de PB e as outras características químicas, esses parâmetros mostraram dois resultados relevantes e significativos (Tabela 13). O primeiro relacionado aos parâmetros de digestibilidade da planta, nota-se que a PB foi correlacionada positivamente com FDNd $(r=0,44)$ e com a digestibilidade "in vitro" da MS da planta $(r=0,24)$ e em segundo, uma correlação negativa entre os teores de $\mathrm{PB}$ e as frações amido $(\mathrm{r}=-0,24)$ e Amidod $(\mathrm{r}=-0,33)$. Pode-se inferir que quanto maior o teor de PB maior será a digestibilidade da planta, desde que esse aumento não interfira no teor de amido da mesma. 
Tabela 13. Coeficientes de correlação linear de Pearson determinados entre as variáveis dos cultivares em Tarumã

\begin{tabular}{|c|c|c|c|c|c|c|c|c|c|c|}
\hline Variáveis & FDNd & FDN & Amidod & Amido & DIVMS & MM & $\mathrm{EE}$ & $\mathrm{PB}$ & FDA & PMS \\
\hline FDNd & - & & & & & & & & & \\
\hline FDN & $\begin{array}{l}-0,638 \\
(0,0001)^{1}\end{array}$ & - & & & & & & & & \\
\hline Amidod & 0,052 & $\begin{array}{l}-0,431 \\
(<0,0001)\end{array}$ & - & & & & & & & \\
\hline Amido & $\begin{array}{l}0,598 \\
(<0,0001)\end{array}$ & $\begin{array}{l}-0,866 \\
(<0,0001)\end{array}$ & $\begin{array}{l}0,593 \\
(<0,0001)\end{array}$ & - & & & & & & \\
\hline DIVMS & $\begin{array}{c}0,387 \\
(0,0005)\end{array}$ & $\begin{array}{l}-0,597 \\
(<0,0001)\end{array}$ & $\begin{array}{l}0,426 \\
(<0,0001)\end{array}$ & $\begin{array}{c}0,423 \\
(<0,0001)\end{array}$ & - & & & & & \\
\hline MM & 0,0741 & 0,160 & $-0,080$ & $\begin{array}{l}-0,381 \\
(<0,0001)\end{array}$ & $\begin{array}{c}0,388 \\
(0,0004)\end{array}$ & - & & & & \\
\hline $\mathrm{EE}$ & $\begin{array}{c}0,280 \\
(0,0127)\end{array}$ & $\begin{array}{l}-0,458 \\
(<0,0001)\end{array}$ & $\begin{array}{c}0,338 \\
(0,0025)\end{array}$ & $\begin{array}{c}0,485 \\
(<0,0001)\end{array}$ & $\begin{array}{c}0,306 \\
(0,0064)\end{array}$ & $\begin{array}{c}0,295 \\
(<, 0087)\end{array}$ & - & & & \\
\hline PB & $\begin{array}{l}0,441 \\
(<0,0001)\end{array}$ & 0,128 & $\begin{array}{r}-0,335 \\
(0,0027)\end{array}$ & $\begin{array}{r}-0,240 \\
(0,0340)\end{array}$ & $\begin{array}{c}0,240 \\
(0,0337)\end{array}$ & 0,103 & $-0,183$ & - & & \\
\hline FDA & $\begin{array}{l}-0,693 \\
(<0,0001)\end{array}$ & $\begin{array}{c}0,786 \\
(<0,0001)\end{array}$ & $\begin{array}{r}-0,296 \\
(0,0084)\end{array}$ & $\begin{array}{c}-0,798 \\
(<0,0001)\end{array}$ & $\begin{array}{l}-0,465 \\
(<0,0001)\end{array}$ & $\begin{array}{c}0,351 \\
(0,0016)\end{array}$ & $\begin{array}{c}-0,285 \\
(<, 0112)\end{array}$ & 0,004 & - & \\
\hline PMS & $-0,168$ & 0,054 & 0,033 & $-0,052$ & 0,092 & 0,170 & $-0,008$ & $-0,045$ & 0,158 & - \\
\hline PMSD & 0,202 & $\begin{array}{c}-0,279 \\
(0,0134)\end{array}$ & $\begin{array}{c}0,269 \\
(<0,0001)\end{array}$ & 0,186 & $\begin{array}{c}0,614 \\
(<0,0001)\end{array}$ & $\begin{array}{c}0,340 \\
(0,0023)\end{array}$ & 0,147 & $-0,168$ & $-0,116$ & $\begin{array}{c}0,838 \\
(<0,0001)\end{array}$ \\
\hline
\end{tabular}

${ }^{1} \mathrm{P}=$ nível descritivo

FDNd= fibra em detergente neutro digestível $;$ FDN= Fibra em detergente neutro; Amidod= amido digestível; DIVMS= digestibilidade "in vitro" da MS; $\mathrm{MM}=$ matéria mineral; $\mathrm{EE}=$ extrato etéreo; $\mathrm{PB}=$ proteína bruta; $\mathrm{FDA}=$ fibra em detergente ácido; $\mathrm{PMS}=$ produção de matéria seca; PMSD=produção de matéria seca digestível. 
$\mathrm{Na}$ determinação da qualidade da silagem, para fins de escolha de cultivares para a produção de silagem, alguns autores (Caetano, 2001; Nussio \& Manzano, 1999) utilizaram um gráfico de dispersão em que os valores da porcentagem de grãos na MS e da DIVMS da planta são plotados nos eixos das abscissas e coordenadas, respectivamente. Para os resultados obtidos na cidade de Tarumã o gráfico foi dividido em quatro quadrantes, adotando-se como critério para distribuição dos mesmos as médias observadas para os parâmetros porcentagem de grãos $(35,5 \%)$ e \% DIVMS (61\%) (Figura 1).

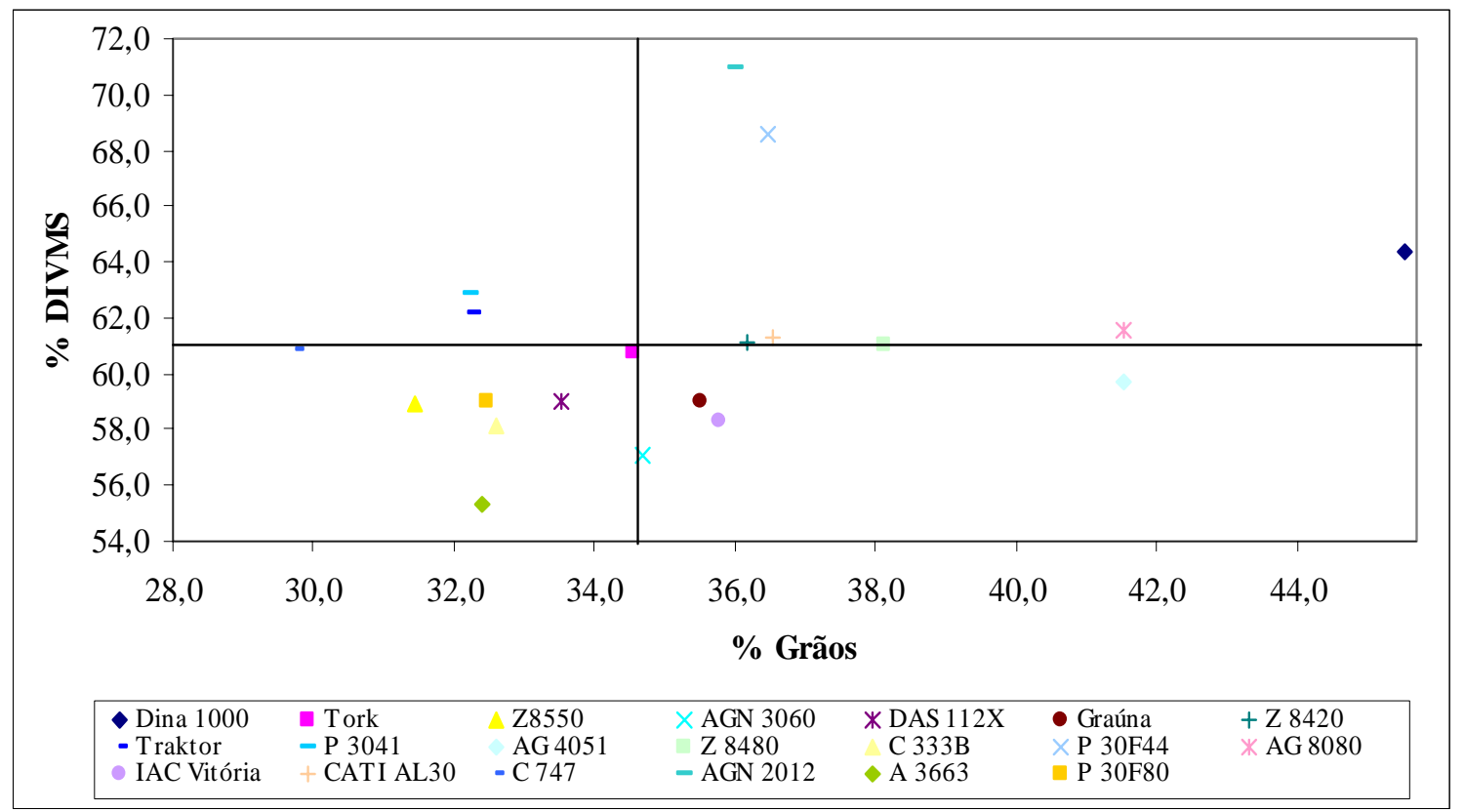

Figura 1 - Relação entre a digestibilidade "in vitro" e a porcentagem de grãos na MS dos cultivares em Piracicaba.

Pode-se visualizar que os cultivares considerados superiores, foram aqueles localizados no quadrante superior direito: Z 8420, AG 8080, Z 8480, Cati AL 30, Dina 1000, AGN 2012 e P30F44. Entretanto, quando se utilizou o critério de Nussio \& Manzano (1999) e Caetano (2001), com os quadrantes sendo divididos nos patamares de $28 \%$ e $61 \%$ para os parâmetros grãos e DIVMS, respectivamente, verificou-se que, além 
daqueles cultivares já citados anteriormente, foram inseridos mais dois, o Traktor e o P 3041.

Ao se comparar os resultados obtidos para o cultivar Dina 1000 nesse experimento constatou-se superioridade na sua qualidade em relação aos obtidos por Caetano (2001); Nussio \& Manzano (1999) observaram no seu estudo que este cultivar comportou-se de forma intermediária. Para o cultivar P 3041, o resultado foi superior no presente estudo e nos trabalhos citados acima.

Através deste tipo de avaliação verifica-se que a porcentagem de grãos seguiu a tendência de dispersão semelhante para a DIVMS da planta, bem como alterações na DIVMS da haste e folha a qual determina variações expressivas na DIVMS da planta toda.

\subsubsection{Mococa}

Neste local, a maior (26.210 $\left.\mathrm{kg} \mathrm{ha}^{-1}\right)$ e menor (17.724 kg ha ${ }^{-1)}$ PMS numérica observada foi para os cultivares A 3663 e Z 8550, respectivamente (Tabela 14). As variações dos valores encontrados na PMS são em função de fatores fenotípicos e genotípicos associados à porcentagem de MS no momento da colheita da planta.

Para as PMSD a média apresentada pelos vinte cultivares analisados foi de 15.445 $\mathrm{kg} \mathrm{ha}^{-1}$. O cultivar com maior valor foi o A 3663 com produção de $18.473 \mathrm{~kg} \mathrm{ha}^{-1}$,o de menor valor foi o P 30F44 com produção de $12.861 \mathrm{~kg} \mathrm{ha}^{-1}$. Ao visualizar-se os quatro locais (Tabelas 10, 14, 18, 22) percebe-se que Mococa foi a cidade com maior PMSD, em função de duas características que foram a alta digestibilidade, e alta produção, tanto de matéria verde como de matéria seca.

As estimativas de DIVMS em Mococa apresentaram os maiores valores em comparação com as demais cidades, com valor médio de 70,9\%. Entretanto não ocorreram diferenças significativas entre os cultivares avaliados para esta análise, com valores variando entre 67,6 a 73,7\% de DIVMS (Tabela 14). 
Os valores encontrados para a DIVMS em Mococa são semelhantes às do trabalho de Johnson et al. (1997), que obtiveram valores entre 68,8 e 70,4\%, quando avaliaram cinco híbridos tropicais. Daynard \& Hunter (1975) também encontraram valores entre 70 e $71,2 \%$ quando avaliaram oito híbridos comerciais durante dois anos consecutivos, colhidos em diferentes épocas de maturidade fisiológica.

Os teores de EE e MM variaram de 1,53 a 2,68\% e 2,41 a 4,19\% respectivamente. Lavezzo et al. (1997) avaliaram a composição químico-bromatológica de alguns cultivares de milho em diferentes estágios de maturidade fisiológica, e observaram que os teores de EE e MM variaram de 2,37 a 2,90\% e 5,00 a 5,50\%, respectivamente, valores maiores quando comparados com os resultados do presente estudo.

No que se refere ao teor de amido, este variou de 22,46 a 33,03\% com média de 27,8\% (Tabela 15); esses valores foram superiores aos obtidos em Tarumã e semelhantes aos encontrados por Moreira (2000), que foram de 20,4 a 30,1\% de amido, ao avaliarem cinco híbridos utilizados para silagem. Quanto à interação entre o teor de amido e a MS, pode-se visualizar que estes foram positivamente correlacionados $(r=0,44)$, portanto, pode-se inferir que quanto maior for teor de MS (maturidade fisiológica) maior será o teor de amido e vice-versa conforme observado por Philippeau \& Michalet-Doreau (1997). Isto pode ser demonstrado através dos cultivares AG 4051, Z 8550 e Dina 1000, onde o cultivar AG 4051 apresentou o maior teor de amido e maior porcentagem de matéria seca dentre os vinte cultivares analisados, enquanto que os dois últimos cultivares (Z 8550 e Dina 1000) foram os que apresentaram os menores teores de amido e conseqüentemente os menores teores de MS.

A média dos teores de FDN foi de 51,42\%, com valores variando de 47,09\% a $54,59 \%$. Esses valores foram inferiores aos obtidos por Johnson et al. (1997), Caetano (2001) e por este experimento nas avaliações realizadas na cidade de Tarumã. Contudo, esses valores foram superiores aos dos cultivares utilizados em países de clima temperado, que geralmente apresentam valores entre 40 e $46 \%$ de FDN (Johnson et al., 1999 e Givens \& Deaville, 2001). Em geral, observou-se que à medida que o teor de FDN aumenta houve decréscimo no teor de amido. 
Tabela 14. Parâmetros agronômicos e frações químicas dos cultivares em Mococa.

\begin{tabular}{|c|c|c|c|c|c|c|}
\hline & & PMS & PMSD & DIVMS & $\mathrm{EE}$ & $\mathrm{MM}$ \\
\hline & & -------------י & $\mathrm{ha}^{-1}$ & ------ & $-\%$ na $\mathrm{M}$ & 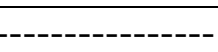 \\
\hline \multirow[t]{20}{*}{ Cultivar } & Dina 1000 & $24.577^{\mathrm{ab}}$ & $17.754^{\mathrm{ab}}$ & 72,2 & $1,53^{\mathrm{d}}$ & $4,19^{\mathrm{a}}$ \\
\hline & Tork & $22.863^{\text {abcde }}$ & $15.797^{\text {abcde }}$ & 69,1 & $2,28^{\text {abcd }}$ & $3,30^{a b c}$ \\
\hline & Z8550 & $17.724^{\mathrm{e}}$ & $12.861^{\mathrm{cde}}$ & 72,6 & $1,93^{\text {abcd }}$ & $3,98^{a b}$ \\
\hline & AGN 3060 & $22.190^{\text {abcde }}$ & $16.331^{\text {abcde }}$ & 73,6 & $1,68^{\mathrm{bcd}}$ & $2,41^{\mathrm{c}}$ \\
\hline & DAS $112 \mathrm{X}$ & $18.405^{\mathrm{cde}}$ & $13.282^{\text {cde }}$ & 72,4 & $2,18^{\text {abcd }}$ & $3,25^{a b c}$ \\
\hline & Graúna 183 & $18.199^{\mathrm{de}}$ & $12.736^{\mathrm{de}}$ & 69,8 & $2,06^{\mathrm{abcd}}$ & $3,91^{\mathrm{ab}}$ \\
\hline & Z 8420 & 21.380 abcde & $14.840^{\text {abcde }}$ & 69,4 & $1,82^{\mathrm{bcd}}$ & $3,76^{a b}$ \\
\hline & Traktor & $22.413^{\text {abcde }}$ & $15.817^{\text {abcde }}$ & 70,4 & $2,30^{a b c}$ & $3,82^{\mathrm{ab}}$ \\
\hline & P 3041 & $23.156^{\text {abcde }}$ & $17.069^{\mathrm{abc}}$ & 73,7 & $2,52^{a b}$ & $4,01^{a b}$ \\
\hline & AG 4051 & $24.207^{\mathrm{ab}}$ & $16.923^{\text {abcd }}$ & 69,8 & $2,68^{\mathrm{a}}$ & $3,51^{a b c}$ \\
\hline & Z 8480 & $23.532^{\mathrm{abcd}}$ & $17.035^{a b c}$ & 72,5 & $1,81^{\mathrm{bcd}}$ & $3,30^{a b}$ \\
\hline & C 333B & $24.199^{a b}$ & $17.031^{\mathrm{abc}}$ & 70,3 & $2,09^{\text {abcd }}$ & $3,58^{a b}$ \\
\hline & P 30F44 & $18.376^{\text {cde }}$ & $12.305^{\mathrm{e}}$ & 67,6 & $2,03^{\mathrm{abcd}}$ & $3,88^{a b}$ \\
\hline & AG 8080 & $22.209^{\text {abcde }}$ & $15.454^{\text {abcde }}$ & 69,6 & $2,22^{\text {abcd }}$ & $3,18^{b c}$ \\
\hline & IAC Vitória & 17.961 de & $13.107^{\text {cde }}$ & 73,0 & $1,84^{\mathrm{bcd}}$ & $3,10^{b c}$ \\
\hline & CATI AL30 & $20.798^{\text {abcde }}$ & $14.347^{\text {abcde }}$ & 68,8 & $1,93^{\mathrm{abcd}}$ & $3,50^{\mathrm{ab}}$ \\
\hline & C 747 & $23.940^{\mathrm{abc}}$ & $16.817^{\mathrm{abcd}}$ & 70,0 & $2,12^{\text {abcd }}$ & $3,95^{\mathrm{ab}}$ \\
\hline & AGN 2012 & $19.713^{\text {bcde }}$ & $13.809^{\text {bcde }}$ & 70,1 & $2,39^{a b c}$ & $4,03^{a b}$ \\
\hline & A 3663 & $26.210^{\mathrm{a}}$ & $18.473^{\mathrm{a}}$ & 70,6 & $2,31^{a b c}$ & $3,79^{a b}$ \\
\hline & P $30 F 33$ & $23.466^{\mathrm{abcd}}$ & $17.109^{a b c}$ & 73,0 & $2,40^{a b c}$ & $3,11^{b c}$ \\
\hline Média & & 21.776 & 15.445 & 70,9 & 2,10 & 3,58 \\
\hline CV (\%) & & 9,85 & 10,55 & 5,24 & 13,59 & 10,27 \\
\hline
\end{tabular}

Médias, na coluna, seguidas de letras diferentes, diferem entre si $(\mathrm{P}<0,05)$ pelo Teste de Tukey.

$\mathrm{CV}=$ coeficiente de variação

$\mathrm{PMS}=$ produção de matéria seca; $\mathrm{PMSD}=$ produção de matéria seca digestível; $\mathrm{EE}=$ extrato etéreo; $\mathrm{MM}=$ matéria mineral; $\mathrm{DIVMS=}$

digestibilidade "invitro" da MS. 
Tabela 15. Frações químicas dos cultivares em Mococa.

\begin{tabular}{|c|c|c|c|c|c|c|c|}
\hline & & Amido & Amidod & FDN & FDNd & FDA & $\mathrm{PB}$ \\
\hline & & & & & $\mathrm{MS}$ & & \\
\hline \multirow[t]{20}{*}{ Cultivar } & Dina 1000 & $22,46^{\mathrm{d}}$ & 99,99 & $54,59^{\mathrm{a}}$ & $58,79^{\mathrm{e}}$ & $29,22^{\mathrm{a}}$ & $5,98^{\mathrm{bcd}}$ \\
\hline & Tork & $29,33^{a b c}$ & 99,99 & $49,86^{a b c}$ & $60,77^{a b c}$ & $25,40^{a b c}$ & $6,40^{\text {abcd }}$ \\
\hline & Z8550 & $24,33^{\mathrm{cd}}$ & 99,98 & $53,47^{\mathrm{ab}}$ & $59,97^{\text {bcde }}$ & $28,32^{\mathrm{ab}}$ & $7,07^{a b c}$ \\
\hline & AGN 3060 & $29,49^{a b c}$ & 100,0 & $49,01 \mathrm{bc}$ & $59,63^{\mathrm{cde}}$ & $24,33^{a b c}$ & $5,92^{\mathrm{cde}}$ \\
\hline & DAS $112 \mathrm{X}$ & $28,79^{\text {abcd }}$ & 99,99 & $51,15^{a b c}$ & $60,62^{\text {abcd }}$ & $23,52^{b c}$ & $6,65^{\text {abcd }}$ \\
\hline & Graúna 183 & $25,60^{\mathrm{cd}}$ & 99,98 & $52,18^{a b c}$ & $60,73^{a b c}$ & $26,93^{a b c}$ & $7,56^{\mathrm{a}}$ \\
\hline & Z 8420 & $26,17^{\mathrm{bcd}}$ & 100,0 & $53,41^{\text {ab }}$ & $59,60^{\text {cde }}$ & $28,06^{\mathrm{ab}}$ & $6,08^{b c d}$ \\
\hline & Traktor & $30,63^{a b c}$ & 99,99 & $49,03 \mathrm{bc}$ & $61,47^{\mathrm{ab}}$ & $24,70^{a b c}$ & $7,19^{a b c}$ \\
\hline & P 3041 & $28,60^{\mathrm{abcd}}$ & 99,99 & $50,77^{a b c}$ & $60,86^{a b c}$ & $27,36^{a b c}$ & $6,00^{\text {bcd }}$ \\
\hline & AG 4051 & $33,03^{\mathrm{a}}$ & 100,0 & $47,09^{\mathrm{c}}$ & $61,49^{a b}$ & $25,14^{a b c}$ & $5,93^{\text {bcd }}$ \\
\hline & Z 8480 & $28,62^{\text {abcd }}$ & 100,0 & $51,04^{a b c}$ & $60,26^{\text {abcde }}$ & $26,64^{a b c}$ & $6,54^{\mathrm{abcd}}$ \\
\hline & C 333B & $27,33^{\text {abcd }}$ & 99,98 & $51,18^{a b c}$ & $60,63^{\text {abcd }}$ & $24,22^{a b c}$ & $7,16^{a b c}$ \\
\hline & P $30 F 44$ & $28,21^{\text {abcd }}$ & 99,99 & $49,26^{a b c}$ & $61,09^{a b c}$ & $25,21^{a b c}$ & $7,30^{a b}$ \\
\hline & AG 8080 & $27,73^{\text {abcd }}$ & 99,99 & $53,34^{a b}$ & $60,23^{\text {abcde }}$ & $26,91^{a b c}$ & 5,99 bcd \\
\hline & IAC Vitória & $27,74^{\text {abcd }}$ & 99,99 & $52,30^{a b c}$ & $60,20^{\text {abcde }}$ & $24,66^{a b c}$ & $6,44^{\text {abcd }}$ \\
\hline & CATI AL30 & $26,09^{\mathrm{bcd}}$ & 99,99 & $53,31^{\text {ab }}$ & $58,97^{\text {de }}$ & $29,03^{\mathrm{a}}$ & $4,60^{\mathrm{e}}$ \\
\hline & C 747 & $26,68^{\mathrm{abcd}}$ & 99,99 & $54,46^{\mathrm{a}}$ & $59,59^{\text {cde }}$ & $28,32^{\text {ab }}$ & $5,62^{\mathrm{de}}$ \\
\hline & AGN 2012 & $27,02^{\text {abcd }}$ & 99,99 & $51,70^{a b c}$ & $60,89^{a b c}$ & $28,48^{a b}$ & $7,23^{a b c}$ \\
\hline & A 3663 & $25,56^{\mathrm{cd}}$ & 99,98 & $54,04^{\mathrm{ab}}$ & 59,99 bcde & $27,03^{a b c}$ & 6,09 bcd \\
\hline & P $30 \mathrm{~F} 33$ & $32,42^{a b}$ & 99,99 & $47,23^{\mathrm{c}}$ & $61,74^{\mathrm{a}}$ & $22,25^{c}$ & $6,67^{\mathrm{abcd}}$ \\
\hline Média & & 27,79 & 99,99 & 51,42 & 60,38 & 26,28 & 6,42 \\
\hline CV (\%) & & 9,03 & 0,009 & 3,94 & 1,01 & 7,51 & 8,13 \\
\hline
\end{tabular}

Médias, na coluna, seguidas de letras diferentes, diferem entre si $(\mathrm{P}<0,05)$ pelo Teste de Tukey.

$\mathrm{CV}=$ coeficiente de variação

$\mathrm{Fdn}=$ fibra em detergente neutro; FDA= Fibra detergente ácido; Fdnd= fibra detergente neutro digestível; Amidod= amido digestível; PB=proteína bruta 
A diferença entre os vinte cultivares para o teor de FDNd foram estatisticamente significativas. O teor médio encontrado foi de $60,38 \%$, variando entre $58,79 \%$ a $61,74 \%$ nos vinte cultivares avaliados. Esses valores foram superiores aos encontrados na cidade de Tarumã e nos estudos avaliados por Caetano (2001), Thomas et al. (2001) e Givens \& Deaville (2001).

Para o teor de amidod verificou-se que não existiu diferença significativa entre os vinte cultivares, com um valor médio de 99,99\%, isso evidencia a alta digestibilidade do amido e portanto um dos principais componentes na digestibilidade da planta toda (Tabela 15).

Os teores de $\mathrm{PB}$ variaram de 4,60 a 7,30\% entre os vinte cultivares, valores estes inferiores aos obtidos por Johnson et al. (1999) em revisão sobre silagem de milho, que encontraram valores de 7,0\% a 9,5\% dependendo da maturidade fisiológica. Os cultivares de milho da cidade de Mococa apresentaram um teor médio de MS de 44\%, isto pode ter interferido no do teor de PB na planta toda.

O teor de FDA apresentou média de 26,28\% para os vinte cultivares analisados, semelhante ao valor encontrado Ballard et al. (2001) observaram teor médio de FDA por volta de $25 \%$ quando três tipos de híbridos foram pesquisados. Penati (1995) ao avaliar vinte cultivares de milho observou um teor médio de $37,48 \%$, o que está bem acima dos valores encontrados neste estudo.

Os coeficientes de correlação obtidos entre a digestibilidade da planta toda e os componentes da haste (FDN e FDA), assim como os parâmetros relacionados ao amido, amidod e FDNd, mostraram-se semelhantes aos encontrados em Tarumã, demonstrando assim, que a digestibilidade da planta está diretamente correlacionada com os teores de amido, FDN e suas respectivas digestibilidades (Tabela 17). Isso pode ser visualizado pelos resultados apresentados na cidade de Tarumã, onde os cultivares com os maiores valores de FDN e FDA foram os que apresentaram menor DIVMS e conseqüentemente menor teor amido (grãos) e digestibilidade do FDN. Em Mococa os resultados foram inversos, com os cultivares apresentando menores teores de FDN e FDA e maiores valores de amido e FDNd. Um exemplo desta interação em Mococa pode ser visualizado 
através do cultivar P 30F33. Isto pode ser explicado através dos teores de MS, já que Mococa apresentou uma alta porcentagem (44\%), levando ao aumento no teor de amido, enquanto Tarumã apresentou porcentagem menor de MS (33\%).

Observou-se também correlação positiva entre a DIVMS, amidod e FDNd, com o teor de amido, fato também verificado em Tarumã, mostrando assim, que há forte interação entre o amido com a digestibilidade da planta toda.

Quando o teor de FDN foi comparado com outros parâmetros químicos constatouse relações positivas com a FDA $(r=0,78)$ e negativas com os teores que representaram a fração grãos, como o amido $(\mathrm{r}=-0,90)$ e o amidod $(\mathrm{r}=-0,42)$, além dos resultados de DIVMS $(\mathrm{r}=-0,56)$ da planta (Tabela 17). Esses resultados corroboram com aqueles obtidos em Tarumã e com os observados por Wolf et al. (1993a); Coors (1996) e Caetano (2001).

Quanto às correlações entre os fatores agronômicos e o teor de FDN, não foram encontradas relações relevantes, mostrando assim um comportamento diferenciado do que foi visto em Tarumã (Tabela 16).

Tabela 16. Correlações entre as principais características agronômicas e frações químicas em Mococa.

\begin{tabular}{cccccc}
\hline Variáveis & DPT & Amido & FDN & FDNd & Amidod \\
\hline G & 0,181 & 0,166 & 0,050 & 0,160 & 0,204 \\
MS & 0,105 & $0,450^{*}$ & $-0,112$ & $-0,042$ & $0,540^{*}$ \\
HP & $-0,124$ & $-0,114$ & 0,090 & 0,007 & $-0,450$ \\
FP & 0,184 & $-0,277$ & 0,117 & $-0,063$ & 0,023 \\
EP & 0,167 & 0,211 & $-0,124$ & 0,019 & $0,394^{*}$
\end{tabular}

* Significativo a 5\% pelo teste de correlação de Pearson.

$\mathrm{G}=$ grãos; $\mathrm{MS}=$ matéria seca; $\mathrm{H} / \mathrm{P}=$ haste/planta; $\mathrm{F} / \mathrm{P}=$ folha/ planta $; \mathrm{E} / \mathrm{P}=$ espiga/planta; $\mathrm{DPT}=$ digestibilidade da planta toda; FDN = fibra em detergente neutro; FDA = fibra em detergente ácido; Amidod = amido digestível; FDNd= fibra em detergente neutro digestível 
Tabela 17. Coeficientes de correlação linear de Pearson determinados entre as variáveis dos cultivares em Mococa

\begin{tabular}{|c|c|c|c|c|c|c|c|c|c|c|}
\hline Variáveis & FDNd & FDN & Amidod & Amido & DIVMS & MM & $\mathrm{EE}$ & $\mathrm{PB}$ & FDA & PMS \\
\hline FDNd & - & & & & & & & & & \\
\hline FDN & $\begin{array}{l}-0,758 \\
(0,0001)^{1}\end{array}$ & - & & & & & & & & \\
\hline Amidod & 0,011 & $\begin{array}{l}-0,418 \\
(<0,0001)\end{array}$ & - & & & & & & & \\
\hline Amido & $\begin{array}{c}0,717 \\
(<0,0001)\end{array}$ & $\begin{array}{l}-0,902 \\
(<0,0001)\end{array}$ & $\begin{array}{c}0,506 \\
(<0,0001)\end{array}$ & - & & & & & & \\
\hline DIVMS & $\begin{array}{c}0,433 \\
(<0,0001)\end{array}$ & $\begin{array}{l}-0,561 \\
(<0,0001)\end{array}$ & $\begin{array}{l}0,251 \\
(0,0247)\end{array}$ & $\begin{array}{l}0,300 \\
(0,0068)\end{array}$ & - & & & & & \\
\hline MM & $-0,157$ & $\begin{array}{c}0,491 \\
(<0,0001)\end{array}$ & $\begin{array}{l}-0,471 \\
(<0,0001)\end{array}$ & $\begin{array}{l}-0,623 \\
(<0,0001)\end{array}$ & $-0,107$ & - & & & & \\
\hline $\mathrm{EE}$ & $\begin{array}{c}0,680 \\
(<0,0001)\end{array}$ & $\begin{array}{l}-0,437 \\
(<0,0001)\end{array}$ & $-0,106$ & $\begin{array}{c}0,549 \\
(<0,0001)\end{array}$ & $-0,167$ & 0,014 & - & & & \\
\hline PB & $\begin{array}{c}0,512 \\
(<0,0001)\end{array}$ & $\begin{array}{l}-0,258 \\
(0,0208)\end{array}$ & $\begin{array}{l}-0,293 \\
(0,0082)\end{array}$ & 0,030 & $\begin{array}{l}0,509 \\
(<0,0001)\end{array}$ & $\begin{array}{c}0,227 \\
(0,0424)\end{array}$ & 0,096 & - & & \\
\hline FDA & $\begin{array}{l}-0,678 \\
(<0,0001)\end{array}$ & $\begin{array}{c}0,782 \\
(<0,0001)\end{array}$ & $\begin{array}{l}-0,302 \\
(0,0063)\end{array}$ & $\begin{array}{l}-0,767 \\
(<0,0001)\end{array}$ & $\begin{array}{l}-0,572 \\
(<0,0001)\end{array}$ & $\begin{array}{c}0,640 \\
(<0,0001)\end{array}$ & $\begin{array}{l}-0,257 \\
(0,0212)\end{array}$ & $\begin{array}{c}-0,304 \\
(0,0060)\end{array}$ & - & \\
\hline PMS & $-0,015$ & $-0,026$ & 0,123 & 0,085 & $-0,132$ & $-0,003$ & 0,139 & $-0,186$ & 0,008 & - \\
\hline PMSD & 0,092 & $-0,168$ & 0,183 & 0,161 & 0,115 & $-0,033$ & 0,094 & $-0,062$ & $-0,134$ & $\begin{array}{c}0,968 \\
(<0,0001)\end{array}$ \\
\hline
\end{tabular}

FDNd= fibra em detergente neutro digestível ; FDN= Fibra em detergente neutro; Amidod= amido digestível; DIVMS= digestibilidade "in vitro" da MS; MM= matéria mineral; $\mathrm{EE}=$ extrato etéreo; $\mathrm{PB}=$ proteína bruta; $\mathrm{FDA}=$ fibra em detergente ácido; $\mathrm{PMS}=$ produção de matéria seca; $\mathrm{PMSD}=$ produção de matéria seca digestível. 
Quanto aos coeficientes de correlação, observa-se que a MS $(r=0,44)$, a haste $(r=$ $-0,45)$ e a espiga $(r=0,39)$ foram os parâmetros químicos e agronômicos que mais se relacionaram com a digestibilidade do amido (Tabelas 16). Quanto às frações químicas verificou-se a mesma tendência encontrada em Tarumã para a digestibilidade do amido, fato também constatado em Mococa (Tabela 17).

Os coeficientes de correlação entre os parâmetros agronômicos (G, H/P, F/P, E/P) e o teor de FDNd não se mostraram significativos (Tabela 16).

Em relação às correlações da PB com as outras características químicas analisadas (Tabela 17), pode-se salientar que esta foi positivamente correlacionada com a DIVMS $(\mathrm{r}=0,51)$ e com a digestibilidade da fração FDN $(\mathrm{r}=0,44)$ mostrando assim a importância desse parâmetro na digestibilidade da planta. Além disso, evidenciam-se correlações negativas do amido e sua fração digestível discutida anteriormente para a cidade de Tarumã. As frações relacionadas à haste, FDN e FDA, apresentaram baixos coeficientes de correlações com o teor de PB.

$\mathrm{Na}$ Tabela 17 as correlações apresentaram-se semelhantes às encontradas na cidade de Tarumã, onde o teor de FDA se correlacionou negativamente com os teores de FDNd $(r=-0,69)$, Amidod $(r=-0,30)$, Amido $(r=-0,80)$ e DIVMS $(r=-0,46)$ e positivamente com o teor de FDN $(r=0,79)$. A única diferença entre as cidades foi para o teor de FDA, onde Tarumã apresentou resultado inferior aos obtidos em Mococa, provavelmente devido à maturidade fisiológica no ponto de colheita, com valores médios de MS de 44\% para os cultivares em Mococa e 33,5\% para os de Tarumã.

A Figura 2 foi plotada nos pontos 39,2\% (\% grãos) no eixo das abscissas e 70,9\% no eixo das coordenadas (\% DIVMS), em virtude de estes serem os pontos médios dos parâmetros analisados. Pode-se visualizar que os cultivares superiores, se localizaram no quadrante superior direito, e esses foram o Z 8550, DAS 112X, P 3041 e o Traktor, mostrando assim uma disposição totalmente diferente da encontrada em Tarumã. Notase que ao se considerar a porcentagem de grãos com $28 \%$ na MS e digestibilidade de 60,1\%, parâmetros adotados por Caetano (2001) e Nussio \& Manzano (1999), todos os outros cultivares seriam agrupados no quadrante superior direito. 


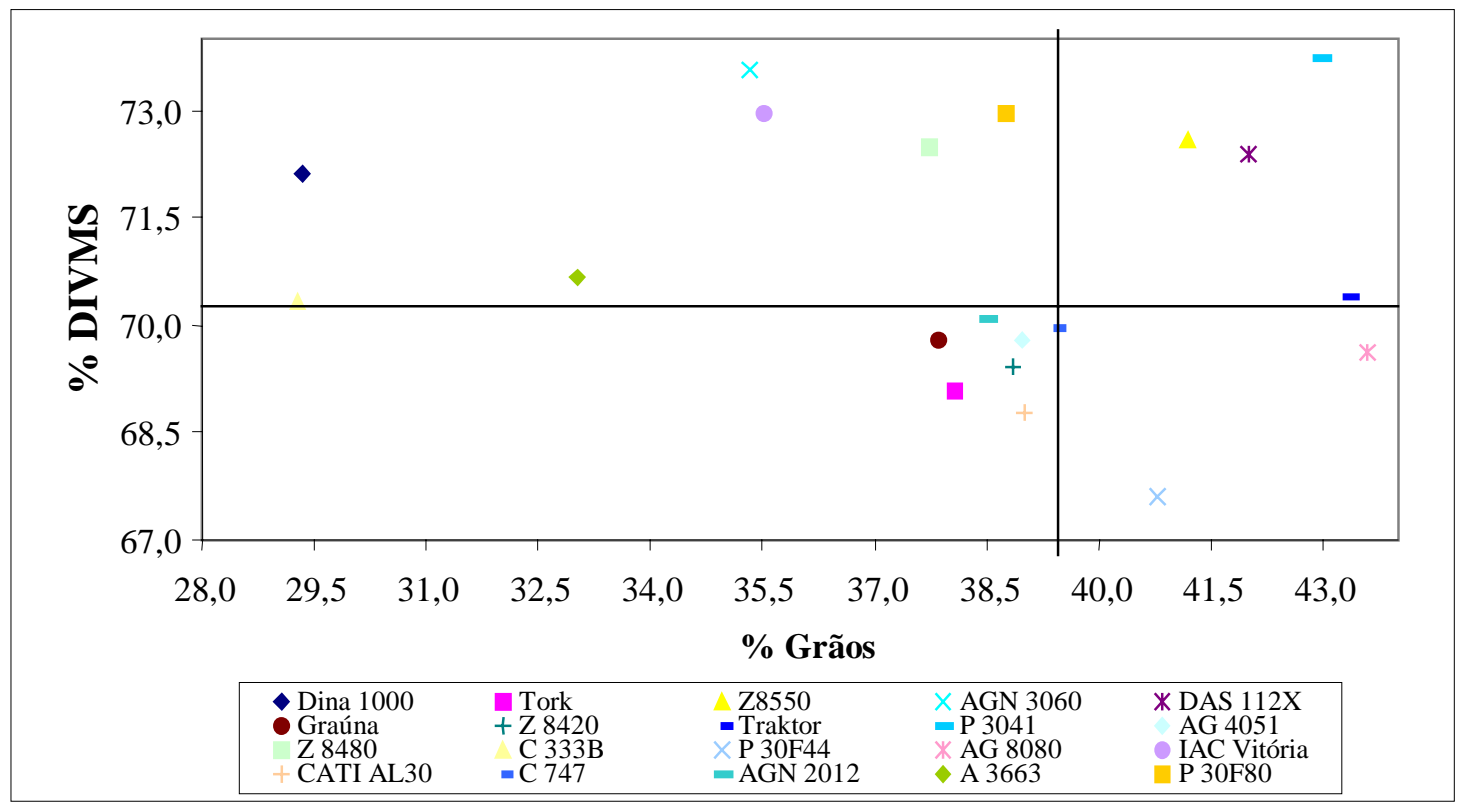

Figura 2 - Relação entre a digestibilidade "in vitro" e a porcentagem de grãos na MS de cultivares em Mococa.

Ao se comparar os resultados do cultivar P 3041, em relação aos resultados obtidos por Nussio \& Manzano (1999) e Caetano (2001), constata-se sua superioridade em todos os estudos, assim como em Tarumã. Pelos resultados apresentados graficamente, evidenciou-se que os vinte cultivares avaliados em Mococa apresentaram a melhor relação, DIVMS x Grãos, em termos de qualidade da planta de milho para silagem comparativamente às outras localidades deste estudo.

\subsubsection{Piracicaba}

$\mathrm{Na}$ tabela 18 estão apresentados os parâmetros agronômicos e frações químicas nos cultivares avaliados em Piracicaba.

As PMS e PMSD foram inferiores se comparadas às outras 3 localidades estudadas nesse trabalho, com médias de $18.523 \mathrm{~kg} \mathrm{ha}^{-1}$ e $9.505 \mathrm{~kg} \mathrm{ha}^{-1}$. Esta diminuição na PMS e conseqüentemente na PMSD dos cultivares avaliados em Piracicaba, foi em função de 
problema climático ocorrido durante o desenvolvimento da cultura, principalmente na fase final de seu desenvolvimento, onde ocorre o enchimento dos grãos (Apêndice 1).

A DIVMS apresentou uma média entre os vinte cultivares avaliados de 51,7\%, sendo que maior valor numérico encontrado foi para o cultivar Z $8550(59,9 \%)$ e o menor para o AGN 3060 (49,1\%), valores inferiores aos encontrados por Johnson et al. (1985), Hunt et al. (1993) e Lundeen (2000). A explicação para esta baixa DIVMS estaria relacionada ao período de enchimento de grãos dos cultivares avaliados em Piracicaba. Nesse período a planta sofreu "stress" hídrico causado por um veranico e com isso a quantidade de amido na planta foi reduzida, levando assim, a uma diminuição na sua digestibilidade. Daynard \& Hunter (1975) observaram que quando a planta de milho ficava sem a fração grãos, esta apresentava digestibilidade inferior nos diferentes estádios de maturidade. Eles também constataram que quanto maior o teor de MS, menor a digestibilidade da planta, sendo este resultado agravado quando a quantidade de grãos era reduzida. Sonon et al. (1993) observaram aumento na digestibilidade quando houve aumento no teor de grãos com o aumento no teor de MS da planta de milho.

Os valores de MM apresentaram média de 2,29\% para os vinte cultivares, sendo que o maior teor ficou para o cultivar Dina 1000 com valor de 3,23\%, e o menor para o AGN 3060 (1,36\%). Em relação ao EE, a média dos cultivares ficou em 1,55\% com valores variando entre $1,07 \%$ e 2,17\%. Em ambos os parâmetros as médias ficaram abaixo do encontrado nas outras cidades avaliadas nesse experimento.

Os teores de FDA e FDN nos vinte cultivares avaliados apresentaram médias de $33,86 \%$ e 56,67\%, respectivamente (Tabela 19). Nos parâmetros FDN e FDA, observouse que os cultivares que apresentaram os maiores teores de FDN foram aqueles com maior teor de FDA e vice-versa; exemplo disso são os cultivares A 3663 e Z 8550, em que o primeiro apresentou maior teor de $\operatorname{FDN}(61,85 \%)$ e FDA $(38,47 \%)$ em relação aos demais cultivares avaliados. Entretanto, no cultivar Z8550 houve uma inversão de valores, com teores de FDN (51,57\%) e FDA $(27,47 \%)$ inferiores aos demais cultivares avaliados. Apesar disso, esses valores médios, de FDN e FDA, encontram-se na faixa observada por Johson et al. (1997) e Henrique et al. (1997). As porcentagens de amido 
dos vinte cultivares analisados apresentaram média geral de 20,60\%. A faixa de variação entre o maior e o menor teor de amido foi para os cultivares Z 8550 e C747, como médias de $27,31 \%$ e $13,52 \%$, respectivamente (Tabela 19). O teor médio de amido foi inferior à média encontrada por Moreira (2000) que observou valor de 26,4\% quando quatro cultivares de milho foram avaliados. Entretanto, esse mesmo autor encontrou valor próximo a Piracicaba para o cultivar do tipo "leafy", com 20,4\%.

A digestibilidade do FDN e do amido apresentaram médias de 59,51\% e 99,98\%, respectivamente, onde os valores de amido digestível pouco variaram. O FDNd apresentou faixa de variação entre 57,45\% e 62,02\% para os cultivares AGN 2012 e C 333B, respectivamente (Tabela 19). Pode-se constatar que o cultivar que obteve o maior valor de DIVMS, Z 8550, foi também aquele que apresentou maior conteúdo de amido e digestibilidade do amido, bem como os maiores valores de digestibilidade do FDN. Demonstrando assim, que essas características (amido, FDN, amidod e FDNd) são importantíssimas na determinação da qualidade da planta de milho. Isso pode ser observado através das correlações entre estas partes digestíveis e a DIVMS da planta toda (Tabela 21).

Quanto ao teor de PB, verificou-se valores abaixo do que foi encontrado na literatura e na avaliação dos mesmos cultivares avaliados nas cidades de Tarumã e Mococa. Os valores variaram entre 2,96\% e 5,84\%, com maior teor de PB ficando com o cultivar C 333B. Através desses valores constatou-se que o teor de PB está muito aquém daquelas obtidas nesse experimento, assim como, em relação as pesquisas realizadas por Hunt et al.(1993) e Henrique et al. (1997). Esse resultado pode ter sido ocasionado pela relação negativa entre a porcentagem de MS e o teor de PB (Lauer, 1996; Lavezzo et al., 1997a) acarretada pelos problemas climáticos ocorridos em Piracicaba, além de problemas que podem ter ocorrido durante a amostragem. 
Tabela 18. Parâmetros agronômicos e frações químicas dos cultivares em Piracicaba.

\begin{tabular}{|c|c|c|c|c|c|c|}
\hline & & PMS & PMSD & DIVMS & $\mathrm{EE}$ & MM \\
\hline & & 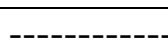 & $\mathrm{ha}^{-1}$ & ----------- & $-\%$ na $\mathrm{N}$ & \\
\hline \multirow[t]{20}{*}{ Cultivar } & Dina 1000 & $20.759^{a b}$ & $10.593^{\mathrm{ab}}$ & $53,0^{\mathrm{bc}}$ & $1,48^{a b c}$ & 3,23 \\
\hline & Tork & $18.097^{\mathrm{ab}}$ & $9.121^{\mathrm{ab}}$ & $50,6^{c}$ & $1,77^{a b c}$ & 2,35 \\
\hline & $\mathrm{Z} 8550$ & $20.984^{\mathrm{ab}}$ & $12.550^{\mathrm{a}}$ & $59,9^{\text {a }}$ & $2,17^{\mathrm{a}}$ & 2,81 \\
\hline & AGN 3060 & $17.841^{\mathrm{ab}}$ & $8.823^{\mathrm{ab}}$ & $49,1^{\mathrm{c}}$ & $1,33^{b c}$ & 1,36 \\
\hline & DAS $112 \mathrm{X}$ & $18.929^{a b}$ & $9.731^{\mathrm{ab}}$ & $54,4^{a b c}$ & $1,81^{a b c}$ & 2,71 \\
\hline & Graúna 183 & $17.465^{\mathrm{ab}}$ & $9.292^{\mathrm{ab}}$ & $55,9^{\mathrm{abc}}$ & $1,42^{b c}$ & 2,79 \\
\hline & Z 8420 & $17.581^{\mathrm{ab}}$ & $9.062^{\mathrm{ab}}$ & $51,6^{\mathrm{bc}}$ & $1,46^{b c}$ & 2,12 \\
\hline & Traktor & $18.078^{\mathrm{ab}}$ & $9.217^{\mathrm{ab}}$ & $50,8^{\mathrm{c}}$ & $1,67^{\mathrm{abc}}$ & 2,11 \\
\hline & P 3041 & $20.176^{\mathrm{ab}}$ & $9.833^{a b}$ & $51,5^{b c}$ & $1,87^{a b c}$ & 2,65 \\
\hline & AG 4051 & $22.070^{\mathrm{a}}$ & $11.269^{\mathrm{ab}}$ & $51,3^{b c}$ & $1,52^{a b c}$ & 2,23 \\
\hline & Z 8480 & $18.608^{a b}$ & $9.584^{a b}$ & $51,6^{\mathrm{bc}}$ & $1,52^{a b c}$ & 1,70 \\
\hline & C $333 B$ & $20.416^{\mathrm{ab}}$ & $11.528^{a b}$ & $56,3^{a b}$ & $1,98^{a b}$ & 2,58 \\
\hline & P $30 F 44$ & $17.592^{\mathrm{ab}}$ & $8.585^{\mathrm{ab}}$ & $49,3^{c}$ & $1,07^{\mathrm{b}}$ & 1,99 \\
\hline & AG 8080 & $20.023^{\mathrm{ab}}$ & $9.969^{\mathrm{ab}}$ & $49,5^{\mathrm{c}}$ & $1,33^{b c}$ & 2,53 \\
\hline & IAC Vitória & $14.395^{\mathrm{b}}$ & $7.462^{b}$ & $53,6^{\mathrm{abc}}$ & $1,45^{b c}$ & 3,21 \\
\hline & CATI AL30 & $15.746^{a b}$ & $7.801^{\mathrm{b}}$ & $49,3^{\mathrm{c}}$ & $1,28^{\mathrm{b}}$ & 2,09 \\
\hline & C 747 & $18.577^{\mathrm{ab}}$ & $7.124^{b}$ & $48,7^{\mathrm{c}}$ & $1,18^{b}$ & 2,61 \\
\hline & AGN 2012 & $17.797^{a b}$ & $8.988^{a b}$ & $50,3^{\mathrm{c}}$ & $1,60^{a b c}$ & 1,72 \\
\hline & A 3663 & $18.288^{a b}$ & $8.744^{a b}$ & $48,0^{\mathrm{c}}$ & $1,17^{\mathrm{b}}$ & 2,30 \\
\hline & P $30 \mathrm{~F} 33$ & $17.046^{\mathrm{ab}}$ & $8.792^{a b}$ & $51,6^{b c}$ & $1,72^{a b c}$ & 2,37 \\
\hline Média & & 18.523 & 9.505 & 51.7 & 1,55 & 2.29 \\
\hline $\mathrm{CV}(\%)$ & & 14,26 & 16,96 & 3,94 & 16,43 & 28,66 \\
\hline
\end{tabular}

Médias, na coluna, seguidas de letras diferentes, diferem entre si $(\mathrm{P}<0,05)$ pelo Teste de Tukey.

$\mathrm{CV}=$ coeficiente de variação

$\mathrm{PMS}=$ produção de matéria seca; $\mathrm{PMSD}=$ produção de matéria seca digestível; $\mathrm{EE}=$ extrato etéreo; $\mathrm{MM}=$ matéria mineral; $\mathrm{DIVMS}=$ digestibilidade "invitro" da MS. 
Tabela 19. Frações químicas dos cultivares em Piracicaba.

\begin{tabular}{|c|c|c|c|c|c|c|c|}
\hline & & Amido & Amidod & FDN & FDNd & FDA & $\mathrm{PB}$ \\
\hline & & & & & MS ----- & & \\
\hline \multirow[t]{20}{*}{ Cultivar } & Dina 1000 & $18,24^{\mathrm{ab}}$ & $99,99^{\mathrm{a}}$ & $58,55^{\mathrm{ab}}$ & $58,49^{\mathrm{cd}}$ & $36,57^{\mathrm{ab}}$ & $3,84^{\mathrm{ab}}$ \\
\hline & Tork & $20,71^{a b}$ & $99,98^{a b}$ & $57,30^{a b}$ & $59,04^{\mathrm{cd}}$ & $33,36^{a b c}$ & $4,13^{a b}$ \\
\hline & $\mathrm{Z} 8550$ & $27,31^{\mathrm{a}}$ & $100,0^{\mathrm{a}}$ & $51,57^{\mathrm{b}}$ & $61,84^{a b}$ & $27,47^{\mathrm{c}}$ & $5,67^{a b}$ \\
\hline & AGN 3060 & $20,07^{\mathrm{ab}}$ & $99,97^{a b c}$ & $55,99^{a b}$ & $59,01^{\mathrm{cd}}$ & $34,45^{a b c}$ & $3,25^{\mathrm{ab}}$ \\
\hline & DAS $112 \mathrm{X}$ & $20,56^{a b}$ & $99,97^{a b c}$ & $56,21^{\text {ab }}$ & $60,81^{a b}$ & $32,86^{a b c}$ & $5,35^{a b}$ \\
\hline & Graúna 183 & $18,51^{a b}$ & $99,95^{a b c}$ & $56,63^{a b}$ & $60,44^{a b}$ & $31,05^{a b c}$ & $5,14^{a b}$ \\
\hline & Z 8420 & $21,12^{a b}$ & $99,97^{a b c}$ & $56,41^{\mathrm{ab}}$ & $59,91^{\text {abcd }}$ & $32,57^{a b c}$ & $5,56^{\mathrm{ab}}$ \\
\hline & Traktor & $20,75^{a b}$ & $99,97^{a b c}$ & $54,04^{a b}$ & $60,36^{a b c}$ & $35,43^{a b c}$ & $5,00^{a b}$ \\
\hline & P 3041 & $21,64^{a b}$ & $99,97^{a b c}$ & $54,23^{a b}$ & $60,18^{\text {abcd }}$ & $35,07^{a b c}$ & $4,84^{\mathrm{ab}}$ \\
\hline & $\mathrm{AG} 4051$ & $21,63^{a b}$ & $99,99^{a b}$ & $55,60^{a b}$ & $59,45^{\text {abcd }}$ & $36,23^{a b c}$ & $5,06^{a b}$ \\
\hline & Z 8480 & $24,45^{\mathrm{ab}}$ & $100,0^{\mathrm{a}}$ & $55,65^{\mathrm{ab}}$ & $59,12^{\mathrm{cd}}$ & $32,06^{a b c}$ & $3,84^{\mathrm{ab}}$ \\
\hline & C $333 B$ & $24,96^{\mathrm{a}}$ & $99,96^{a b c}$ & $51,03^{b}$ & $62,02^{\mathrm{a}}$ & $29,30^{b c}$ & $5,84^{\text {a }}$ \\
\hline & P $30 F 44$ & $18,99^{a b}$ & $99,98^{a b c}$ & $60,91^{\mathrm{a}}$ & $57,48^{\mathrm{d}}$ & $33,80^{a b c}$ & $3,08^{b}$ \\
\hline & AG 8080 & $16,78^{a b}$ & $99,95^{b c}$ & $58,32^{a b}$ & $58,70^{\mathrm{cd}}$ & $36,54^{a b c}$ & $4,59^{a b}$ \\
\hline & IAC Vitória & $16,41^{\mathrm{ab}}$ & $99,98^{a b c}$ & $61,17^{\mathrm{a}}$ & $59,13^{\text {bcd }}$ & $33,69^{a b c}$ & $4,64^{\mathrm{ab}}$ \\
\hline & CATI AL30 & $17,21^{\mathrm{ab}}$ & $99,96^{a b c}$ & $59,15^{\mathrm{ab}}$ & $59,26^{\mathrm{bcd}}$ & $35,51^{a b c}$ & $5,19^{a b}$ \\
\hline & C 747 & $13,52^{b}$ & $99,97^{a b c}$ & $66,85^{\mathrm{a}}$ & $56,95^{\mathrm{d}}$ & $36,32^{a b c}$ & $2,96^{b}$ \\
\hline & AGN 2012 & $22,52^{a b}$ & $99,98^{a b c}$ & $55,45^{a b}$ & $59,72^{\text {abcd }}$ & $33,94^{a b c}$ & $4,41^{a b}$ \\
\hline & A 3663 & $13,90^{b}$ & $99,94^{\mathrm{c}}$ & $61,85^{\mathrm{a}}$ & $57,45^{d}$ & $38,47^{\mathrm{a}}$ & $3,41^{a b}$ \\
\hline & P $30 F 33$ & $23,28^{a b}$ & $99,99^{a b}$ & $54,65^{a b}$ & $59,88^{\text {abcd }}$ & $33,61^{a b c}$ & $4,10^{a b}$ \\
\hline Média & & 20,59 & 99,97 & 56,67 & 59,51 & 33,86 & 4,51 \\
\hline $\mathrm{CV}(\%)$ & & 19,32 & 0,014 & 6,11 & 1,65 & 9,43 & 21,75 \\
\hline
\end{tabular}

Médias, na coluna, seguidas de letras diferentes, diferem entre si $(\mathrm{P}<0,05)$ pelo Teste de Tukey.

$\mathrm{CV}=$ coeficiente de variação

$\mathrm{Fdn}=$ fibra em detergente neutro; FDA= Fibra detergente ácido; Fdnd= fibra detergente neutro digestível; Amidod= amido digestível; PB=proteína bruta 
Em relação às outras cidades, Piracicaba apresentou valores similares aos obtidos nos cultivares avaliados em Tarumã, apesar dessa última possuir uma diferença na porcentagem de MS (mais de 10\%) da planta toda de milho. Isto demonstra que Piracicaba está com o teor de amido abaixo do esperado, já que a porcentagem de amido aumenta com o avanço da maturidade fisiológica.

As correlações da DIVMS em Piracicaba foram positivas em relação aos parâmetros amido, amidod, PB e digestibilidade do FDN. Essas correlações evidenciaram, mais uma vez, a importância da digestibilidade da haste em relação à planta toda. Porém, para os componentes da haste, FDN e FDA, as correlações foram negativas como encontrado anteriormente nos outros locais avaliados.

Para os coeficientes de correlação dos parâmetros agronômicos e químicos com o amido, ressalta-se a relação deste com a DIVMS $(r=0,68)$, mostrando assim, a importância do amido na qualidade da planta de milho. Para a correlação entre o teor de amido e a porcentagem de MS ( $\mathrm{r}=0,28)$, apesar de não ser elevada é um importante parâmetro a ser observado.

Tabela 20. Correlações entre as principais características agronômicas e frações químicas em Piracicaba.

\begin{tabular}{cccccc}
\hline Variáveis & DPT & Amido & FDN & FDNd & Amidod \\
\hline MS & 0,286 & 0,280 & $-0,015$ & 0,021 & $0,550^{*}$ \\
HP & 0,054 & $-0,154$ & 0,040 & 0,170 & $-0,140$ \\
FP & 0,080 & $-0,302$ & 0,230 & $-0,150$ & $-0,301$ \\
EP & 0,086 & 0,280 & 0,080 & 0,053 & 0,263 \\
\hline
\end{tabular}

* Significativo a 5\% pelo teste de correlação de Pearson.

$\mathrm{G}=$ grãos; $\mathrm{MS}=$ matéria seca; $\mathrm{H} / \mathrm{P}$ = haste/planta; $\mathrm{F} / \mathrm{P}=$ folha/ planta; $\mathrm{E} / \mathrm{P}=$ espiga/planta;

DPT $=$ digestibilidade da planta toda $;$ FDN = fibra em detergente neutro; FDA = fibra em detergente ácido; Amidod = amido digestível; FDNd= fibra em detergente neutro digestível 
Tabela 21. Coeficientes de correlação linear de Pearson determinados entre as variáveis dos cultivares em Piracicaba

\begin{tabular}{|c|c|c|c|c|c|c|c|c|c|c|}
\hline Varáveis & FDNd & FDN & Amidod & Amido & DIVMS & MM & $\mathrm{EE}$ & PB & FDA & PMS \\
\hline FDNd & - & & & & & & & & & \\
\hline FDN & $\begin{array}{c}-0,872 \\
(0,0001)^{1}\end{array}$ & - & & & & & & & & \\
\hline Amidod & $\begin{array}{c}0,266 \\
(0,0346)\end{array}$ & $\begin{array}{r}-0,449 \\
(0,0002)\end{array}$ & - & & & & & & & \\
\hline Amido & $\begin{array}{l}0,748 \\
(<0,0001)\end{array}$ & $\begin{array}{l}-0,896 \\
(<0,0001)\end{array}$ & $\begin{array}{l}0,684 \\
(<0,0001)\end{array}$ & - & & & & & & \\
\hline DIVMS & $\begin{array}{l}0,588 \\
(<0,0001)\end{array}$ & $\begin{array}{l}-0,691 \\
(<0,0001)\end{array}$ & $\begin{array}{l}0,593 \\
(<0,0001)\end{array}$ & $\begin{array}{l}0,682 \\
(<0,0001)\end{array}$ & - & & & & & \\
\hline MM & 0,089 & 0,047 & $-0,094$ & $\begin{array}{c}-0,256 \\
(0,0446)\end{array}$ & $\begin{array}{c}0,385 \\
(0,0020)\end{array}$ & - & & & & \\
\hline $\mathrm{EE}$ & $\begin{array}{l}0,834 \\
(<0,0001)\end{array}$ & $\begin{array}{l}-0,804 \\
(<0,0001)\end{array}$ & $\begin{array}{c}0,328 \\
(0,0091)\end{array}$ & $\begin{array}{l}0,679 \\
(<0,0001)\end{array}$ & $\begin{array}{l}0,595 \\
(<0,0001)\end{array}$ & 0,248 & - & & & \\
\hline PB & $\begin{array}{c}0,632 \\
(<0,0001)\end{array}$ & $\begin{array}{c}-0,389 \\
(0,0017)\end{array}$ & $-0,352$ & 0,015 & $\begin{array}{c}0,421 \\
(0,0006)\end{array}$ & $\begin{array}{l}0,515 \\
(<0,0001)\end{array}$ & $\begin{array}{l}0,468 \\
(<0,0001)\end{array}$ & - & & \\
\hline FDA & $\begin{array}{l}-0,716 \\
(<0,0001)\end{array}$ & $\begin{array}{l}0,655 \\
(<0,0001)\end{array}$ & $\begin{array}{l}-0,514 \\
(<0,0001)\end{array}$ & $\begin{array}{l}-0,824 \\
(<0,0001)\end{array}$ & $\begin{array}{l}-0,600 \\
(<0,0001)\end{array}$ & 0,232 & $\begin{array}{l}-0,473 \\
(<0,0001)\end{array}$ & $-0,207$ & - & \\
\hline PMS & 0,243 & $\begin{array}{c}-0,320 \\
(0,0104)\end{array}$ & 0,190 & $\begin{array}{c}0,362 \\
(0,0035)\end{array}$ & $\begin{array}{c}0,281 \\
(0,0253)\end{array}$ & $-0,133$ & 0,230 & $-0,016$ & $\begin{array}{r}-0,348 \\
(0,0056)\end{array}$ & - \\
\hline PMSD & $\begin{array}{l}0,492 \\
(<0,0001)\end{array}$ & $\begin{array}{l}-0,597 \\
(<0,0001)\end{array}$ & $\begin{array}{l}0,460 \\
(<0,0001)\end{array}$ & $\begin{array}{c}0,626 \\
(<0,0001)\end{array}$ & $\begin{array}{c}0,748 \\
(<0,0001)\end{array}$ & 0,124 & $\begin{array}{l}0,490 \\
(<0,0001)\end{array}$ & 0,214 & $\begin{array}{c}-0,574 \\
(<0,0001) \\
\end{array}$ & $\begin{array}{c}0,841 \\
(<0,0001) \\
\end{array}$ \\
\hline
\end{tabular}

FDNd= fibra em detergente neutro digestível ; FDN= Fibra em detergente neutro; Amidod= amido digestível; DIVMS= digestibilidade "in vitro" da $\mathrm{MS} ; \mathrm{MM}=$ matéria mineral; $\mathrm{EE}=$ extrato etéreo; $\mathrm{PB}=$ proteína bruta; $\mathrm{FDA}=$ fibra em detergente ácido; $\mathrm{PMS}=$ produção de matéria seca; PMSD=produção de matéria seca digestível 
Os coeficientes de correlação dos parâmetros agronômicos e químicos de FDN e FDA, esses se mostraram bem semelhantes aos resultados obtidos dos cultivares avaliados nas cidades de Tarumã e Mococa.

Quanto aos fatores agronômicos pode-se visualizar que a MS tem papel importante na digestibilidade do amido pelo coeficiente apresentado $(r=0,55)$ (Tabela 20).

Os coeficientes de correlação encontrados entre o teor de PB e os outros parâmetros assemelham-se aos encontrados nos cultivares avaliados nas cidades de Tarumã e Mococa.

Como na cidade de Piracicaba não houve avaliação da \% de grãos na planta toda, utilizou-se como base para a representação da classificação dos cultivares os valores médios das outras três cidades avaliadas neste estudo (Figura 3).

Os quadrantes do gráfico foram divididos nos eixos das coordenadas e das abscissas com base nos valores médios da \% de grãos (35\%) e DIVMS (51,7\%), respectivamente. Através da Figura 3, observa-se que os cultivares considerados superiores, aqueles localizados no quadrante superior direito, foram o Graúna 183, Z 8550 e o DAS $112 X$.

Ao considerar o parâmetro $28 \%$ para a porcentagem de grãos na MS, e $60,1 \%$ para a digestibilidade "in vitro", que foi o utilizado por Nussio \& Manzano (1999) e Caetano (2001), verifica-se que somente o cultivar Z 8550 se aproxima do quadrante superior direito. Provavelmente pela baixa DIVMS que os cultivares apresentaram em Piracicaba. Portanto, nenhum cultivar em Piracicaba estaria dentro dos padrões de classificação superior quanto a qualidade da planta de milho, mostrando assim, que o problema não foi ocasionado pelos cultivares mas sim pelo desenvolvimento da cultura, principalmente na fase final, onde ocorre o enchimento dos grãos. 


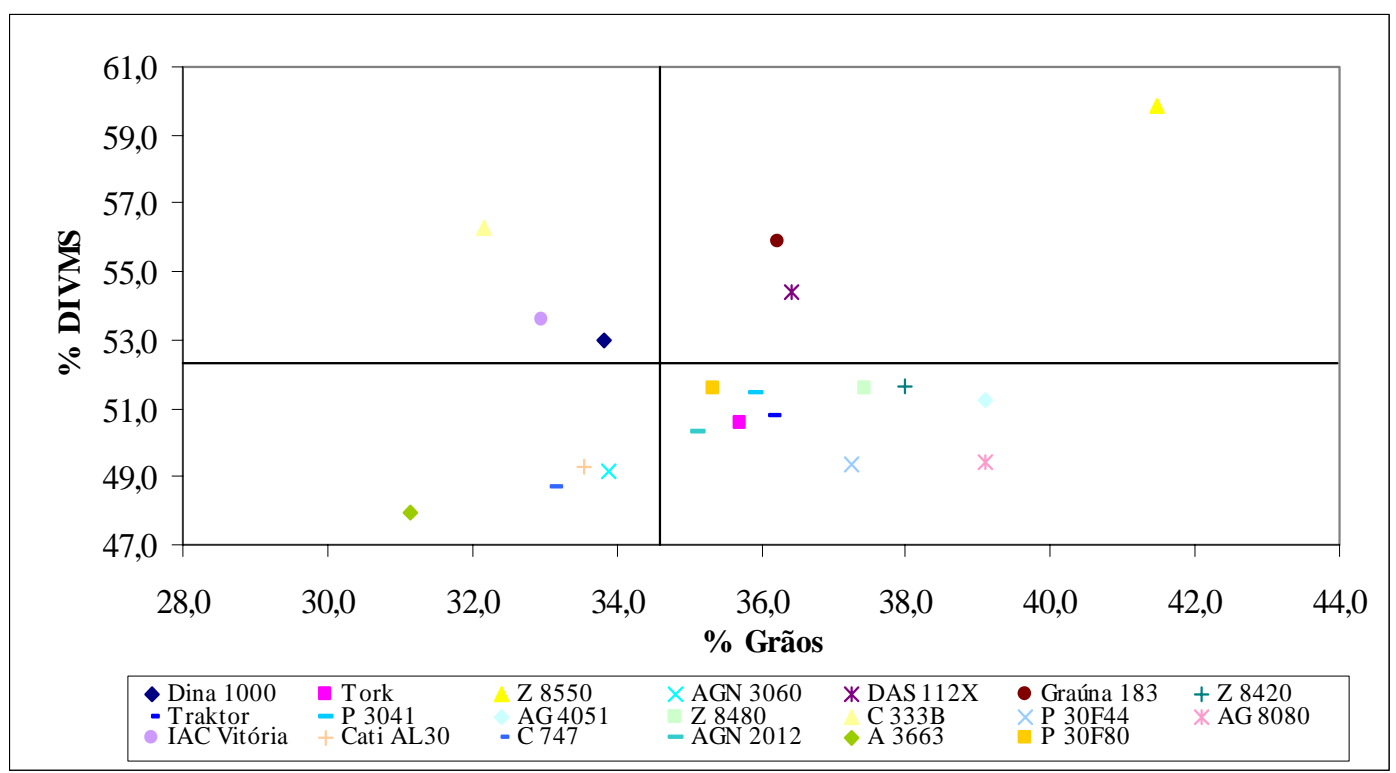

Figura 3 - Relação entre a digestibilidade "in vitro" e a porcentagem de grãos na MS dos cultivares em Piracicaba.

\subsubsection{Votuporanga}

As PMS e PMSD apresentaram média de 21.232 e $11.809 \mathrm{~kg} \mathrm{ha}^{-1}$ nos vinte cultivares analisados. Para a PMS o maior valor numérico foi para o cultivar AGN 3060 com uma produção de $24.382 \mathrm{~kg} \mathrm{ha}^{-1}$, enquanto para a PMSD os maiores valores numéricos foram os cultivares AGN 3060 e AG 8080, com produções de 13.503 e $13.591 \mathrm{~kg} \mathrm{ha}^{-1}$, respectivamente (Tabela 22). Os valores médios obtidos em Votuporanga estão mais próximos dos resultados encontrados nas cidades de Mococa, demonstrando que a localidade, em função dos fatores ambientais podem influenciar a PMS e conseqüentemente a PMSD.

A DIVMS não foi significativamente diferente $(\mathrm{P}>0,05)$ entre os vinte cultivares analisados, apresentando valores médios de 55,52\%. A variação entre eles mostrou-se pequena $(4,8 \%)$ entre o cultivar mais expressivo, Graúna 183 e o 
menos expressivo, C 747. Os valores obtidos nas avaliações dos cultivares na cidade de Votuporanga ficaram acima daqueles avaliados em Piracicaba e abaixo dos resultados obtidos em Mococa e Tarumã. Almeida Filho et al. (1999) encontraram valores inferiores de DIVMS quando analisaram nove diferentes cultivares de milho. Entretanto, Shaver (1999) ao avaliar dois tipos de híbridos encontrou valores acima de $60 \%$ de digestibilidade.

Os cultivares de milho avaliados nessa cidade apresentaram valores de matéria mineral (MM) variando entre 3,41\% e 1,43\% para os cultivares $\mathrm{P} 3041$ e Tork, respectivamente (Tabela 22). Quanto ao teor de EE, este apresentou valor médio entre os cultivares analisados de $2,22 \%$.

Para o teor de FDN, os vinte cultivares avaliados apresentaram média de $55,75 \%$ (Tabela 23), sendo que o maior teor numérico de FDN observado foi do cultivar A 3663 com 59,61\%. Caetano (2001), ao avaliar a composição química da planta de milho encontrou valores $(57,68 \%)$ acima da média deste trabalho. Entretanto, Santos et al. (2002) encontraram valores inferiores aos apresentados no presente trabalho ao avaliarem diferentes híbridos de milho no Paraná, evidenciando que a localização geográfica é um dos principais fatores de variação na qualidade da fibra e portanto, na qualidade da planta de milho.

Quanto ao teor de amido, este apresentou média geral de 21,89\%, o que está acima dos valores obtidos nos cultivares da cidade de Tarumã e Piracicaba e inferiores ao valor obtido em Mococa. O maior teor numérico de amido foi observado para o cultivar Z 8420 e o menor para o Dina 1000 com variação de $10,28 \%$ entre estes. Shaver (1999) observou valores entre 29,0 e $35,8 \%$ de amido ao avaliar dois híbridos, o que está acima do valor encontrado em Votuporanga. Entretanto, Bal et al. (2000) observaram valores de amido variando entre 18,2 e $37,4 \%$ quando as plantas de milho avançaram na sua maturidade fisiológica.

Os aspectos mencionados por Bal et al. (2000) podem ser confirmados através das correlações entre os aspectos agronômicos e o teor de amido da planta (Tabela 22), onde o teor de amido possuiu relação positiva e significativa com a 
porcentagem de MS, assim como com a porcentagem de grãos e espigas na planta. Isso demonstra que o teor de amido possui uma relação diretamente proporcional com a MS, sendo que o aumento na MS resultará em aumento no teor de amido da planta.

As características digestíveis dos parâmetros amidod e FDNd apresentaram médias de $99,917 \%$ e $62,53 \%$, respectivamente para os vinte cultivares analisados. A digestibilidade do amido foi elevada em relação aos resultados obtidos por Shaver (1999), Bal et. al. (2000) e Andrae et al. (2001). Em Votuporanga observou-se a mesma tendência de resultados para os parâmetros amidod, quando esse foi comparado com os resultados obtidos nas cidades de Tarumã, Piracicaba e Mococa avaliadas nesse experimento.

Quanto ao FDNd, verifica-se que esse variou entre 60,27\% e 63,95\% para os vinte cultivares avaliados. Em contraste com os resultados apresentados nesse estudo, Kuehn et al. (1996) verificaram que a digestibilidade do FDN na planta de milho variou de $45,0 \%$ a 46,1\%, em dois anos consecutivos de avaliação.

Os teores de fibra em detergente ácido (FDA) e proteína bruta (PB), não apresentaram diferenças entre os vinte cultivares $(\mathrm{P}>0,05)$ (Tabelas 23). As médias obtidas para FDA e PB foram de 27,75\% e 5,45\%, respectivamente. Apesar de não apresentar diferença significativa no teor de FDA as variações entre os cultivares Tork e C 747, que representam o menor e o maior valor, respectivamente, foi superior a 10\%, sendo este um diferencial importante já que a FDA é uma fração da haste e portanto pouco digestível. Johnson et al. (1999) em revisão realizada sobre a composição da planta de milho nos diferentes estágios fisiológicos e de maturação, observaram valores de FDA entre 23,9 e 38,5\%.

Quanto aos teores de PB, estes foram inferiores aos cultivares avaliados nas cidades de Mococa e Tarumã, e superiores aos cultivados em Piracicaba, com teores variando entre 4,25 e 6,56\% para os cultivares analisados. Valores próximos aos encontrados em Votuporanga foram obtidos por Hunt et al. (1993). 
Tabela 22. Parâmetros agronômicos e frações químicas dos cultivares em Votuporanga.

\begin{tabular}{lllllll}
\hline & & PMS & PMSD & DIVMS & EE & MM \\
\hline \multirow{3}{*}{ Cultivar } & Dina 1000 & $22.890^{\mathrm{abc}}$ & $12.546^{\mathrm{ab}}$ & 54,9 & 1,94 & $3,29^{\mathrm{a}}$ \\
& Tork & $22.164^{\mathrm{abc}}$ & $12.498^{\mathrm{ab}}$ & 56,4 & 2,48 & $1,43^{\mathrm{b}}$ \\
& Z8550 & $19.438^{\mathrm{bc}}$ & $11.098^{\mathrm{ab}}$ & 57,2 & 1,80 & $3,09^{\mathrm{a}}$ \\
& AGN 3060 & $24.382^{\mathrm{a}}$ & $13.503^{\mathrm{a}}$ & 55,7 & 2,24 & $2,30^{\mathrm{ab}}$ \\
& DAS 112X & $21.392^{\mathrm{abc}}$ & $11.725^{\mathrm{ab}}$ & 54,8 & 2,26 & $1,99^{\mathrm{ab}}$ \\
& Graúna 183 & $18.903^{\mathrm{bc}}$ & $10.964^{\mathrm{ab}}$ & 57,9 & 2,38 & $2,60^{\mathrm{ab}}$ \\
& Z 8420 & $19.861^{\mathrm{bc}}$ & $11.297^{\mathrm{ab}}$ & 57,0 & 2,15 & $1,75^{\mathrm{ab}}$ \\
& Traktor & $19.514^{\mathrm{bc}}$ & $10.538^{\mathrm{b}}$ & 54,6 & 2,50 & $3,23^{\mathrm{a}}$ \\
& P 3041 & $18.747^{\mathrm{c}}$ & $10.156^{\mathrm{b}}$ & 54,1 & 2,57 & $3,41^{\mathrm{a}}$ \\
& AG 4051 & $22.068^{\mathrm{abc}}$ & $12.376^{\mathrm{ab}}$ & 56,1 & 2,45 & $2,12^{\mathrm{ab}}$ \\
& Z 8480 & $20.934^{\mathrm{abc}}$ & $11.543^{\mathrm{ab}}$ & 55,2 & 2,37 & $2,17^{\mathrm{ab}}$ \\
& C 333B & $23.187^{\mathrm{abc}}$ & $12.582^{\mathrm{ab}}$ & 54,8 & 2,46 & $2,14^{\mathrm{ab}}$ \\
& P 30F44 & $21.158^{\mathrm{abc}}$ & $12.179^{\mathrm{ab}}$ & 57,4 & 2,45 & $2,91^{\mathrm{ab}}$ \\
& AG 8080 & $24.445^{\mathrm{a}}$ & $13.591^{\mathrm{a}}$ & 55,6 & 2,00 & $2,07^{\mathrm{ab}}$ \\
& IAC Vitória & $19.054^{\mathrm{bc}}$ & $10.134^{\mathrm{b}}$ & 53,2 & 1,89 & $2,42^{\mathrm{ab}}$ \\
& CATI AL30 & $22.564^{\mathrm{abc}}$ & $12.787^{\mathrm{ab}}$ & 56,7 & 2,26 & $2,94^{\mathrm{ab}}$ \\
CV́dia $(\%)$ & C 747 & $20.927^{\mathrm{abc}}$ & $11.147^{\mathrm{ab}}$ & 53,1 & 1,79 & $2,98^{\mathrm{ab}}$ \\
& AGN 2012 & $19.746^{\mathrm{bc}}$ & $10.898^{\mathrm{ab}}$ & 55,2 & 2,13 & $2,66^{\mathrm{ab}}$ \\
& A 3663 & $21.981^{\mathrm{abc}}$ & $12.279^{\mathrm{ab}}$ & 56,1 & 2,11 & $2,22^{\mathrm{ab}}$ \\
& P 30F80 & $21.297^{\mathrm{abc}}$ & $12.031^{\mathrm{ab}}$ & 56,5 & 2,16 & $2,16^{\mathrm{ab}}$
\end{tabular}

Médias, na coluna, seguidas de letras diferentes, diferem entre si $(\mathrm{P}<0,05)$ pelo Teste de Tukey.

$\mathrm{CV}=$ coeficiente de variação

$\mathrm{PMS}=$ produção de matéria seca; $\mathrm{PMSD}=$ produção de matéria seca digestível; $\mathrm{EE}=$ extrato etéreo; $\mathrm{MM}=$ matéria mineral; $\mathrm{DIVMS=}$ digestibilidade "invitro" da MS. 
Tabela 23. Frações químicas dos cultivares em Votuporanga.

\begin{tabular}{|c|c|c|c|c|c|c|c|}
\hline & & Amido & Amidod & FDN & FDNd & FDA & $\mathrm{PB}$ \\
\hline & & -------- & --- & 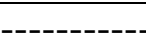 & MS ----.. & 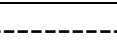 & ---- \\
\hline \multirow[t]{20}{*}{ Cultivar } & Dina 1000 & $17,31^{\mathrm{c}}$ & $99,91^{\mathrm{b}}$ & $59,00^{\mathrm{a}}$ & $61,25^{\mathrm{cd}}$ & 30,78 & 5,94 \\
\hline & Tork & $25,89^{a b c}$ & $99,92^{a b}$ & $53,69^{a b}$ & $63,72^{a b}$ & 22,39 & 4,87 \\
\hline & Z8550 & $20,25^{a b c}$ & $99,92^{a b}$ & $57,85^{\mathrm{a}}$ & $61,22^{\mathrm{cd}}$ & 27,97 & 5,85 \\
\hline & AGN 3060 & $26,33^{a b}$ & $99,93^{a b}$ & $49,64^{b}$ & $62,54^{\text {abcd }}$ & 26,66 & 4,25 \\
\hline & DAS $112 \mathrm{X}$ & $24,15^{a b c}$ & $99,93^{\mathrm{ab}}$ & $56,12^{a b}$ & $62,90^{\mathrm{abc}}$ & 26,82 & 4,69 \\
\hline & Graúna 183 & $23,76^{\mathrm{abc}}$ & $99,90^{b}$ & $52,75^{\mathrm{ab}}$ & $63,87^{\mathrm{a}}$ & 24,57 & 6,27 \\
\hline & Z 8420 & $27,59^{\mathrm{a}}$ & $99,95^{\mathrm{a}}$ & $53,34^{a b}$ & $63,95^{\mathrm{a}}$ & 22,67 & 6,06 \\
\hline & Traktor & $20,25^{a b c}$ & $99,90^{b}$ & $55,55^{\mathrm{ab}}$ & $63,07^{a b c}$ & 30,58 & 6,26 \\
\hline & P 3041 & $17,77^{\mathrm{bc}}$ & $99,90^{b}$ & $57,93^{\mathrm{a}}$ & $63,01^{a b c}$ & 31,50 & 6,30 \\
\hline & AG 4051 & $25,57^{a b c}$ & $99,93^{\mathrm{ab}}$ & $53,42^{a b}$ & $62,99^{a b c}$ & 27,19 & 4,84 \\
\hline & Z 8480 & $22,40^{a b c}$ & $99,93^{a b}$ & $56,42^{\mathrm{ab}}$ & $62,70^{a b c}$ & 27,63 & 6,04 \\
\hline & C $333 B$ & $22,69^{a b c}$ & $99,91^{\mathrm{b}}$ & $56,54^{a b}$ & $63,10^{a b c}$ & 26,47 & 4,74 \\
\hline & P $30 F 44$ & $22,73^{a b c}$ & $99,93^{a b}$ & $54,62^{a b}$ & $63,27^{a b c}$ & 27,52 & 6,56 \\
\hline & AG 8080 & $22,37^{a b c}$ & $99,91^{\mathrm{b}}$ & $56,16^{a b}$ & $62,14^{\mathrm{abcd}}$ & 26,68 & 5,58 \\
\hline & IAC Vitória & $18,70^{b c}$ & $99,92^{a b}$ & $56,53^{a b}$ & $61,61^{\text {abcd }}$ & 31,39 & 5,09 \\
\hline & CATI AL30 & $21,74^{\mathrm{abc}}$ & $99,91^{\mathrm{b}}$ & $55,08^{a b}$ & $62,45^{\text {abcd }}$ & 27,42 & 4,97 \\
\hline & C 747 & $17,77^{\mathrm{bc}}$ & $99,90^{b}$ & $59,32^{\mathrm{a}}$ & $60,27^{\mathrm{d}}$ & 32,44 & 5,11 \\
\hline & AGN 2012 & $20,19^{a b c}$ & $99,90^{b}$ & $55,39^{a b}$ & $62,62^{\text {abcd }}$ & 29,09 & 5,28 \\
\hline & A 3663 & $18,15^{b c}$ & $99,90^{b}$ & $59,61^{\mathrm{a}}$ & $61,40^{\mathrm{bcd}}$ & 28,64 & 5,31 \\
\hline & P $30 F 80$ & $22,21^{a b c}$ & $99,93^{\mathrm{ab}}$ & $56,14^{a b}$ & $62,57^{\text {abcd }}$ & 26,68 & 5,00 \\
\hline Média & & 21,89 & 99,92 & 55,75 & 62,53 & 27,75 & 5,45 \\
\hline CV (\%) & & 15,17 & 0,017 & 5,39 & 1,47 & 15,06 & 21,52 \\
\hline
\end{tabular}

Médias, na coluna, seguidas de letras diferentes, diferem entre si $(\mathrm{P}<0,05)$ pelo Teste de Tukey.

$\mathrm{CV}=$ coeficiente de variação

$\mathrm{Fdn}=$ fibra em detergente neutro; FDA= Fibra detergente ácido; Fdnd= fibra detergente neutro digestível; Amidod= amido digestível; PB=proteína bruta 
Entretanto, Johnson et al. (1997) observaram teores de PB variando entre $7,7 \%$ e $9,1 \%$, quando diferentes híbridos tropicais de milho foram avaliados durante dois anos consecutivos.

Os resultados de correlação entre os parâmetros químicos e a DIVMS mostraram-se semelhantes em relação aos valores obtidos nas outras cidades avaliadas nesse estudo e em outros estudos também (Wolf et al.,1993a; Kuehn et al., 1996).

As correlações entre os teores de FDN e as frações da planta (Tabela 22) foram mais consistentes em termos numéricos do que nas outras cidades avaliadas nesse estudo, e mostraram claramente a relação negativa do teor de FDN com as porcentagens de MS e grãos da planta de milho. Demonstrando assim, que os dois parâmetros (MS e grãos) são inversamente proporcionais ao teor de FDN. Allen et al. (1991) e Wolf et al. (1993a) encontraram correlações semelhantes às desse estudo. Com relação aos parâmetros químicos, estes foram semelhantes aos encontrado nas cidades avaliadas nesse estudo, demonstrando que as relações entre os parâmetros químicos foram consistentes em todas as localidades desse estudo.

Tabela 24. Correlações entre as principais características agronômicas e frações químicas em Votuporanga.

\begin{tabular}{cccccc}
\hline Variáveis & DPT & Amido & FDN & FDNd & Amidod \\
\hline G & 0,331 & $0,687^{*}$ & $-0,446^{*}$ & 0,188 & $0,531^{*}$ \\
MS & 0,020 & $0,674^{*}$ & $-0,411$ & $-0,302$ & $0,550^{*}$ \\
HP & $-0,387$ & $-0,347$ & 0,060 & $-0,295$ & $-0,472$ \\
FP & $-0,140$ & $-0,434$ & 0,198 & $-0,220$ & $-0,181$ \\
EP & 0,376 & $0,540^{*}$ & $-0,174$ & 0,292 & 0,467 \\
\hline
\end{tabular}

* Significativo a 5\% pelo teste de correlação de Pearson.

$\mathrm{G}=$ grãos; $\mathrm{MS}=$ matéria seca; $\mathrm{H} / \mathrm{P}=$ haste/planta; $\mathrm{F} / \mathrm{P}=$ folha/ planta; $\mathrm{E} / \mathrm{P}=$ espiga/planta; $\quad \mathrm{DPT}=$ digestibilidade da planta toda; FDN = fibra em detergente neutro; FDA = fibra em detergente ácido; Amidod = amido digestível digestível; FDNd= fibra em detergente neutro digestível 
Tabela 25. Coeficientes de correlação linear determinados entre as variáveis dos cultivares em Votuporanga

\begin{tabular}{|c|c|c|c|c|c|c|c|c|c|c|}
\hline Variáveis & FDNd & FDN & Amidod & Amido & DIVMS & MM & $\mathrm{EE}$ & PB & FDA & PMS \\
\hline FDNd & - & & & & & & & & & \\
\hline FDN & $\begin{array}{c}-0,625 \\
(0,0001)^{1}\end{array}$ & - & & & & & & & & \\
\hline Amidod & $\begin{array}{c}0,286 \\
(0,0101)\end{array}$ & $\begin{array}{l}-0,526 \\
(<0,0001)\end{array}$ & - & & & & & & & \\
\hline Amido & $\begin{array}{c}0,689 \\
(<0,0001)\end{array}$ & $\begin{array}{l}-0,863 \\
(<0,0001)\end{array}$ & $\begin{array}{l}0,704 \\
(<0,0001)\end{array}$ & - & & & & & & \\
\hline DIVMS & $\begin{array}{l}0,410 \\
(<0,0001)\end{array}$ & $\begin{array}{l}-0,570 \\
(<0,0001)\end{array}$ & $\begin{array}{l}0,613 \\
(<0,0001)\end{array}$ & $\begin{array}{l}0,448 \\
(<0,0001)\end{array}$ & - & & & & & \\
\hline MM & $\begin{array}{c}-0,304 \\
(0,0060)\end{array}$ & 0,170 & $\begin{array}{c}-0,241 \\
(0,0310)\end{array}$ & $\begin{array}{l}-0,458 \\
(<0,0001)\end{array}$ & $\begin{array}{c}0,270 \\
(0,0152)\end{array}$ & - & & & & \\
\hline $\mathrm{EE}$ & $\begin{array}{c}0,699 \\
(<0,0001)\end{array}$ & $\begin{array}{r}-0,364 \\
(0,0009)\end{array}$ & 0,089 & $\begin{array}{c}0,370 \\
(0,0007)\end{array}$ & $-0,117$ & 0,007 & - & & & \\
\hline PB & 0,174 & $-0,167$ & $\begin{array}{r}-0,365 \\
(0,0009)\end{array}$ & 0,144 & $\begin{array}{l}0,515 \\
(<0,0001)\end{array}$ & $\begin{array}{c}0,300 \\
(0,0068)\end{array}$ & 0,132 & - & & \\
\hline FDA & $\begin{array}{l}-0,531 \\
(<0,0001)\end{array}$ & $\begin{array}{c}0,575 \\
(<0,0001)\end{array}$ & $\begin{array}{c}-0,571 \\
(<0,0001)\end{array}$ & $\begin{array}{c}-0,793 \\
(<0,0001)\end{array}$ & $\begin{array}{r}-0,369 \\
(0,0007)\end{array}$ & $\begin{array}{c}0,533 \\
(<0,0001)\end{array}$ & $-0,119$ & $\begin{array}{c}-0,323 \\
(0,0034)\end{array}$ & - & \\
\hline PMS & - ,0201 & $-0,115$ & 0,035 & 0,178 & 0,069 & - 0,190 & 0,001 & $\begin{array}{c}-0,330 \\
(0,0028)\end{array}$ & $-0,080$ & - \\
\hline PMSD & $-0,044$ & $\begin{array}{l}-0,539 \\
(<0,0001)\end{array}$ & $\begin{array}{c}0,527 \\
(<0,0001)\end{array}$ & $\begin{array}{l}0,459 \\
(<0,0001)\end{array}$ & $\begin{array}{l}0,868 \\
(<0,0001)\end{array}$ & 0,135 & $-0,096$ & $\begin{array}{c}0,263 \\
(0,0183)\end{array}$ & $\begin{array}{c}-0,340 \\
(0,0020)\end{array}$ & $\begin{array}{c}0,548 \\
(<0,0001)\end{array}$ \\
\hline
\end{tabular}

${ }^{\mathrm{I}} \mathrm{P}=$ nível descritivo

FDNd= fibra em detergente neutro digestível $; \mathrm{FDN}=$ Fibra em detergente neutro; Amidod= amido digestível; DIVMS= digestibilidade "in vitro" da MS; $\mathrm{MM}=$ matéria mineral; $\mathrm{EE}=$ extrato etéreo; $\mathrm{PB}=$ proteína bruta; $\mathrm{FDA}=$ fibra em detergente ácido; $\mathrm{PMS}=$ produção de matéria seca;

PMSD=produção de matéria seca digestível. 
No referente às correlações entre as características químicas, observa-se relação positiva do amido com os teores de FDNd, DIVMS e amidod e relação inversa com a FDN e a FDA, demonstrando assim, que o amido tem influência direta na digestibilidade da planta toda e conseqüentemente na qualidade da planta.

Nas correlações do amidod com os parâmetros agronômicos e bromatológicos, nenhuma diferença foi encontrada em relação ao observado nas outras cidades.

O teor de FDNd apresentou correlação negativa em relação às porcentagens de haste e MS da planta de milho. Contudo, nos resultados químicos o FDNd se correlacionou positivamente com os teores de amido, amidod e DIVMS e negativamente com os teores de FDN e FDA, apresentando assim a mesma tendência de resultados observados nas avaliações dos mesmos cultivares nas cidades de Tarumã, Piracicaba e Mococa.

Nas correlações dos teores de PB e FDA com os outros parâmetros químicos (Tabela 25), observa-se que as relações mais significativas seguiram no mesmo padrão que constatado pelos resultados dos cultivares das outras cidades.

Os quadrantes da Figura 4 foram divididos no eixo das coordenadas e das abscissas de acordo com a média da porcentagem de grãos $(32,4 \%)$ e DIVMS $(55,52 \%)$, respectivamente, dos cultivares analisados.

Através da Figura 4, pode-se visualizar nitidamente os cultivares considerados superiores (quadrante superior direito), que no caso de Votuporanga foram: P 30F44, Z 8550, Z 8420, AG 8080 e AG 4051, mostrando assim, uma disposição diferente das encontradas anteriormente nas outras cidades (Tarumã, Piracicaba e Mococa). Ao considerar o parâmetro $28 \%$ para porcentagem de grãos na MS e digestibilidade de 60,1\% de acordo com Nussio \& Manzano (1999) e Caetano (2001), verifica-se que todos os cultivares não estariam inseridos no grupo de cultivares superiores, provavelmente devido aos baixos valores da DIVMS encontrados em Votuporanga. 


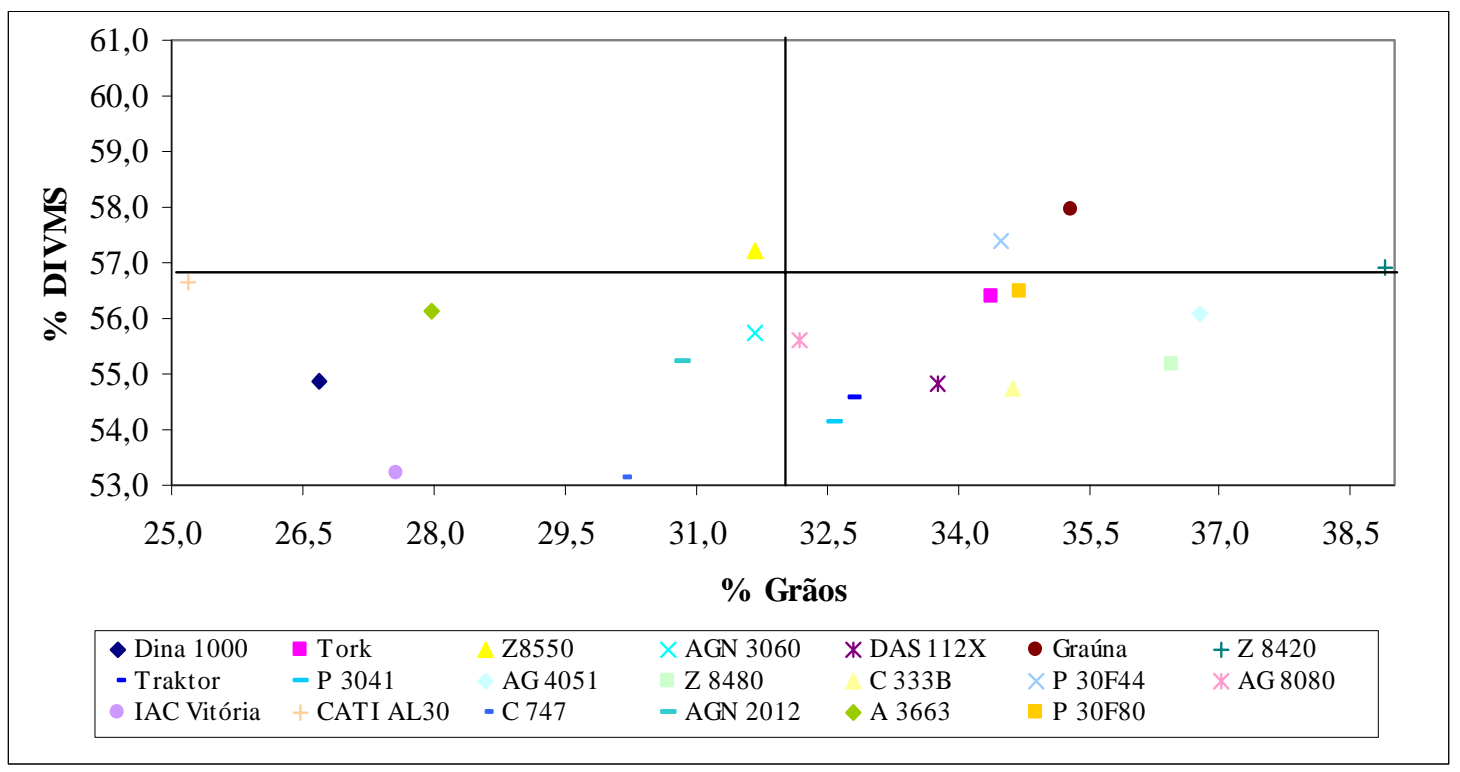

Figura 4 - Relação entre a digestibilidade "in vitro" e a porcentagem de grãos na MS dos cultivares em Votuporanga.

\subsubsection{Haste}

\subsubsection{Tarumã}

Os teores médios de FDN, FDNd e a digestibilidade "in vitro" da fração haste $(\mathrm{DIVH})$ e os respectivos coeficientes de variação (CV) encontram-se na Tabela 26. Os teores de FDN, nos vinte cultivares, não apresentaram diferenças significativas $(\mathrm{P}>0,05)$ entre os cultivares avaliados. Apesar da não existência de diferença estatística entre os valores de FDN da haste, observa-se que houve uma diferença numérica entre os cultivares de maior expressão, Z 8420 com 80,03\%, e menor expressão, IAC Vitória com 71,08\%, com valor médio de 74,05\% entre os vinte cultivares. Caetano (2001), 
avaliando mais especificamente a fração colmo da planta de milho, encontrou valores médios de $73,20 \%$ o que está próximo do valor de FDN da haste desse experimento.

Lundvall et al. (1994) observaram valores de FDN na haste variando entre 48,9 e $66,5 \%$ para cultivares colhidos precocemente, e valores entre 58,3 e 79,1\% para uma colheita mais tardia (ponto de maturidade fisiológica), mostrando que estes valores estão próximos aos valores obtidos em Tarumã. Tolera et al. (1999) também observaram valores próximos (de 74,6 a 76,9\%) a este estudo, que variaram conforme o período de maturidade fisiológica da planta.

A DIVH apresentou média de $42,15 \%$ entre os vinte cultivares analisados com uma variação numérica de $15 \%$ entre o maior e o menor valor (Tabela 26). Hunter (1978) encontrou valores acima de 50\% de digestibilidade para a haste, o que foi superior ao encontrado nesse trabalho. Hunt et al. (1993) obtiveram valores variando entre 46,5 e 61,9\% ao avaliarem dois híbridos de milho, sendo que a forma de determinação (DIVMS ou DISMS) desses valores foi o fator que mais afetou a variação na digestibilidade da haste. Hunt et al. (1992) encontraram valores de digestibilidade da haste variando entre 51,2 e 45,9\%, nesse caso a causa de variação foi o aumento da maturidade da planta de milho no ponto de colheita. Russel (1986) relatou que a digestibilidade "in vitro" da haste declinou com o avanço da maturidade da planta de milho.

Os teores médios de FDNd da fração haste apresentaram valor médio de 53,28\% entre os vinte cultivares analisados. A FDNd da haste variou entre 52,34 e 54,38\% nos cultivares avaliados. Hunt et al. (1993) encontraram valores entre 64,7 e 68,0\% de digestibilidade da FDN na haste, o que são superiores aos encontrados nesse trabalho. 
Tabela 26. Frações químicas da haste dos cultivares em Tarumã

\begin{tabular}{|c|c|c|c|}
\hline Cultivar & FDNd & FDN & DIVH \\
\hline & \multicolumn{3}{|c|}{----------- \% na MS ------------- } \\
\hline Dina 1000 & $53,83^{\mathrm{ab}}$ & 71,55 & $44,99^{\mathrm{a}}$ \\
\hline Tork & $53,29^{a b}$ & 73,56 & $39,98^{a b}$ \\
\hline Z8550 & $52,60^{\mathrm{ab}}$ & 77,81 & $42,59^{\mathrm{ab}}$ \\
\hline AGN 3060 & $53,34^{\mathrm{ab}}$ & 77,41 & $42,07^{\mathrm{ab}}$ \\
\hline DAS $112 X$ & $53,52^{a b}$ & 70,96 & $44,44^{\mathrm{a}}$ \\
\hline Graúna 183 & $52,80^{\mathrm{ab}}$ & 79,74 & $44,57^{\mathrm{a}}$ \\
\hline Z 8420 & $52,55^{a b}$ & 80,03 & $42,89^{a b}$ \\
\hline Traktor & $53,68^{\mathrm{ab}}$ & 75,77 & $41,77^{\mathrm{ab}}$ \\
\hline P 3041 & $53,75^{\mathrm{ab}}$ & 71,09 & $43,29^{a b}$ \\
\hline AG 4051 & $52,34^{b}$ & 75,90 & $38,26^{b}$ \\
\hline Z 8480 & $53,42^{a b}$ & 72,92 & $42,99^{\mathrm{ab}}$ \\
\hline C 333B & $53,35^{\text {ab }}$ & 72,98 & $42,29^{a b}$ \\
\hline P 30F44 & $53,52^{a b}$ & 71,82 & $41,53^{a b}$ \\
\hline AG 8080 & $53,33^{a b}$ & 72,98 & $40,97^{\mathrm{ab}}$ \\
\hline IAC Vitória & $54,38^{\mathrm{a}}$ & 71,08 & $43,31^{\mathrm{ab}}$ \\
\hline CATI AL30 & $53,39^{a b}$ & 73,14 & $41,58^{a b}$ \\
\hline C 747 & $53,24^{\mathrm{ab}}$ & 71,27 & $42,44^{a b}$ \\
\hline AGN 2012 & $52,78^{\mathrm{ab}}$ & 74,72 & $39,73^{a b}$ \\
\hline A 3663 & $53,68^{a b}$ & 74,22 & $42,92^{a b}$ \\
\hline P 30F80 & $52,65^{\mathrm{ab}}$ & 73,49 & $41,01^{\mathrm{ab}}$ \\
\hline Média & 53,28 & 74,05 & 42,15 \\
\hline C V $(\%)$ & 1,42 & 5,48 & 4,89 \\
\hline
\end{tabular}

Os coeficientes de correlação dos componentes da fração haste analisada e o teor de FDN da mesma foram significativamente correlacionados (Tabela 27). Neste sentido, Lundvall et al. (1994) verificaram as mesmas relações observadas nesse experimento e concluíram que a DIVH relacionou-se melhor com o teor de FDN do que qualquer outro componente da parede celular. Constataram ainda, que a relação entre a FDN e a DIVH foi mais forte quando o milho foi colhido em estágio mais precoce de maturidade. Através dessas correlações, também foi possível observar que além do teor de FDN, a 
digestibilidade do mesmo (FDNd) está relacionada com a digestibilidade da haste e conseqüentemente com a qualidade da planta toda de milho.

As correlações entre os componentes da haste, envolvendo o teor de FDNd da mesma (Tabela 27), mostram uma relação significativa e negativa entre o teor de FDN e sua digestibilidade, isto é, quanto maior o teor de FDN na haste menor será sua digestibilidade. Outro resultado significativo, só que desta vez positivo, foi a interação entre o teor de FDNd da haste e a DIVH $(r=0,52)$, demonstrando assim, que a digestibilidade da haste sofreu uma forte influência do teor de FDN digestível.

Tabela 27. Coeficientes de correlação determinados entre as variáveis da haste $(\mathrm{H})$ em Tarumã.

\begin{tabular}{lccccc}
\hline & FDNd (H) & FDN $(\mathrm{H})$ & DIVH & MS & DPT \\
\hline FDNd (H) & \multicolumn{2}{c}{1} & & & \\
FDN (H) & $-0,656^{*}$ & & 1 & & \\
DIVH & $0,521^{*}$ & $-0,395^{*}$ & 1 & & 1 \\
MS & $-0,089$ & $-0,347$ & $-0,419^{*}$ & & 1 \\
DPT & 0,066 & $-0,178$ & $-0,010$ & 0,259 & 1 \\
*Variação ao nível de 5\% de significância \\
FDNd (H) = Fdn digestível da porção haste, FDN (H)= FDN da porção haste, DIVH= digestibilidade "in \\
da fração haste, MS = matéria seca, DPT = digestibilidade "in vitro" da planta toda.
\end{tabular}

A correlação da DIVH com o teor de MS apresentou valore negativo $(r=-0,42)$ (Tabela 27). Isso mostra, que à medida que a porcentagem de matéria seca aumenta a digestibilidade da haste tende a reduzir.

\subsubsection{Mococa}

Os teores de FDNd da haste apresentaram média de 53,38\% para os diferentes cultivares avaliados, sendo o cultivar Traktor o mais expressivo numericamente nesse parâmetro $(54,13 \%)$ (Tabela 28). Esses valores são semelhantes aos resultados obtidos em Tarumã que apresentou média de 53,28\%, para o FDN. 
Tabela 28. Frações químicas da haste dos cultivares em Mococa.

\begin{tabular}{|c|c|c|c|}
\hline Cultivar & FDNd & FDN & DIVH \\
\hline & \multicolumn{3}{|c|}{------------- \% na MS ------------- } \\
\hline Dina 1000 & $53,68^{a b}$ & 68,58 & $50,71^{a b c}$ \\
\hline Tork & $53,67^{\mathrm{ab}}$ & 67,89 & $52,80^{\mathrm{ab}}$ \\
\hline $\mathrm{Z} 8550$ & $53,61^{\mathrm{ab}}$ & 68,11 & $51,74^{\mathrm{abc}}$ \\
\hline AGN 3060 & $53,18^{a b}$ & 67,41 & $47,30^{\mathrm{abc}}$ \\
\hline DAS $112 \mathrm{X}$ & $53,49^{a b}$ & 68,75 & $50,46^{a b c}$ \\
\hline Graúna 183 & $53,89^{a b}$ & 68,22 & $52,97^{\mathrm{ab}}$ \\
\hline Z 8420 & $53,28^{a b}$ & 69,40 & $50,06^{a b c}$ \\
\hline Traktor & $54,13^{\mathrm{a}}$ & 66,18 & $52,20^{a b c}$ \\
\hline P 3041 & $53,28^{a b}$ & 70,96 & $52,01^{a b c}$ \\
\hline AG 4051 & $52,33^{b}$ & 70,88 & $46,81^{\mathrm{bc}}$ \\
\hline Z 8480 & $52,96^{\mathrm{ab}}$ & 72,65 & $48,84^{a b c}$ \\
\hline C $333 B$ & $54,11^{\mathrm{a}}$ & 66,32 & $51,69^{a b c}$ \\
\hline P 30F44 & $53,39^{\mathrm{ab}}$ & 69,76 & $51,28^{a b c}$ \\
\hline AG 8080 & $52,87^{\mathrm{ab}}$ & 70,68 & $46,21^{\mathrm{c}}$ \\
\hline IAC Vitória & $53,24^{\mathrm{ab}}$ & 69,68 & $49,75^{a b c}$ \\
\hline CATI AL30 & $53,25^{\mathrm{ab}}$ & 67,52 & $49,10^{a b c}$ \\
\hline C 747 & $53,34^{\mathrm{ab}}$ & 70,31 & $49,46^{a b c}$ \\
\hline AGN 2012 & $53,33^{\mathrm{ab}}$ & 70,90 & $50,15^{a b c}$ \\
\hline A 3663 & $53,81^{\mathrm{ab}}$ & 65,20 & $51,19^{a b c}$ \\
\hline P 30F33 & $52,84^{\mathrm{ab}}$ & 67,96 & $53,54^{\mathrm{a}}$ \\
\hline Média & 53,38 & 68,87 & 50,41 \\
\hline $\mathrm{CV}(\%)$ & 1,21 & 4,14 & 4,92 \\
\hline
\end{tabular}

Quanto ao teor de FDN não foi constatada significância entre os vinte cultivares avaliados $(\mathrm{P}>0,05)$, apresentando variação numérica de 10,25\% entre os cultivares de maior (Z 8480) e menor expressão (A 3663), o valor médio entre todos os cultivares foi de $68,87 \%$. Contudo, os valores observados no teor de FDN para os cultivares avaliados em Mococa mostraram-se inferiores aos encontrados por Lundvall et al., (1994) e Tolera et al., (1999). Provavelmente pelo maior teor de MS das plantas no momento da colheita. 
Para os resultados de DIVH observou-se variação numérica de $14 \%$ entre o maior (P 30F33) e menor (AG 4051) resultado de DIVH. A média da DIVH dos vinte cultivares de milho na cidade de Mococa $(50,41 \%)$ foi superior ao valor constatado em Tarumã $(42,2 \%)$, provavelmente pelo menor teor de FDN apresentado nos cultivares de Mococa, sendo este comprovado pelo elevado coeficiente de correlação negativo entre o teor de FDNd da haste e a DIVH (Tabela 29).

Tabela 29. Coeficientes de correlação determinados entre as variáveis da haste em Mococa.

\begin{tabular}{|c|c|c|c|c|c|}
\hline & FDNd (H) & $\mathrm{FDN}(\mathrm{H})$ & DIVH & MS & DPT \\
\hline$\overline{\mathrm{FDNd}(\mathrm{H})}$ & & & & & \\
\hline $\mathrm{FDN}(\mathrm{H})$ & $-0,794^{*}$ & & & & \\
\hline DIVH & $0,628^{*}$ & $-0,436^{*}$ & & & \\
\hline MS & $-0,112$ & $-0,058$ & $-0,051$ & & \\
\hline DPT & $-0,092$ & 0,064 & $-0,049$ & 0,259 & \\
\hline
\end{tabular}

*Variação ao nível de 5\% de significância

FDNd $(\mathrm{H})=$ fdn digestível da porção haste, FDN $(\mathrm{H})=$ FDN da porção haste, DIVH= digestibilidade "in vitro" da fração haste, MS = matéria seca, DPT = digestibilidade "in vitro" da planta toda

Quanto às correlações, pode-se constatar a relação negativa entre os teores de FDNd e de FDN na haste, evidenciando portanto, a premissa observada em Tarumã, de que quanto maior o teor de FDN na haste menor será a digestibilidade da mesma (Tabela 29). Com relação a DIVH pode-se observar que houve relação positiva com o teor de FDNd, fato também observado nos resultados obtidos em Tarumã.

\subsubsection{Votuporanga}

$\mathrm{Na}$ cidade de Votuporanga, os parâmetros FDN, FDNd e DIVH dos vinte cultivares avaliados estão apresentados na Tabela 30. Os valores de FDNd variaram em 4,0\% (51,90 e 54,0\%), com um valor médio de 52,84\%. O teor de FDN apresentou variação de $16,8 \%$, com os valores variando entre $64,05 \%$ e $76,95 \%$ para os cultivares avaliados. Quanto a DIVH, esta apresentou média de 37,28\%, com valores entre 34,75\% e $39,66 \%$. 
Tabela 30. Frações químicas da haste dos cultivares em Votuporanga.

\begin{tabular}{|c|c|c|c|}
\hline Cultivar & FDNd & FDN & DIVH \\
\hline & \multicolumn{3}{|c|}{-------------- \% na MS ------------- } \\
\hline Dina 1000 & $52,78^{a b c}$ & $72,74^{\text {abcd }}$ & $37,31^{\mathrm{ab}}$ \\
\hline Tork & $52,69^{a b c}$ & $71,72^{\text {abcd }}$ & $36,09^{a b}$ \\
\hline Z8550 & $52,25^{\mathrm{c}}$ & $71,62^{\text {abcd }}$ & $37,93^{\mathrm{ab}}$ \\
\hline AGN 3060 & $53,94^{\mathrm{ab}}$ & $64,05^{\mathrm{d}}$ & $38,14^{\mathrm{ab}}$ \\
\hline DAS $112 X$ & $52,95^{\mathrm{abc}}$ & $71,66^{\text {abcd }}$ & $36,80^{a b}$ \\
\hline Graúna 183 & $52,66^{\mathrm{abc}}$ & $76,30^{\mathrm{ab}}$ & $36,30^{a b}$ \\
\hline Z 8420 & $52,35^{\mathrm{bc}}$ & $76,95^{\mathrm{a}}$ & $35,70^{a b}$ \\
\hline Traktor & $52,98^{a b c}$ & $72,54^{\mathrm{abcd}}$ & $36,73^{a b}$ \\
\hline P 3041 & $51,90^{\mathrm{c}}$ & $75,12^{a b}$ & $34,75^{b}$ \\
\hline AG 4051 & $52,45^{a b c}$ & $71,73^{\mathrm{abcd}}$ & $37,80^{\mathrm{ab}}$ \\
\hline Z 8480 & $52,24^{\mathrm{c}}$ & $72,83^{\mathrm{abc}}$ & $36,65^{\mathrm{ab}}$ \\
\hline C 333B & $52,75^{a b c}$ & $73,21^{a b c}$ & $38,32^{a b}$ \\
\hline P 30F44 & $52,70^{a b c}$ & $75,03^{\mathrm{ab}}$ & $35,81^{a b}$ \\
\hline AG 8080 & $52,40^{a b c}$ & $71,61^{\text {abcd }}$ & $36,61^{a b}$ \\
\hline IAC Vitória & $54,00^{\mathrm{a}}$ & $64,10^{d}$ & $38,83^{a b}$ \\
\hline CATI AL30 & $53,27^{a b c}$ & $69,18^{\text {abcd }}$ & $38,98^{\mathrm{a}}$ \\
\hline C 747 & $52,87^{\mathrm{abc}}$ & $70,32^{\text {abcd }}$ & $38,48^{a b}$ \\
\hline AGN 2012 & $52,94^{a b c}$ & $67,74^{\text {bcd }}$ & $37,73^{a b}$ \\
\hline A 3663 & $53,90^{\mathrm{ab}}$ & $65,70^{\mathrm{cd}}$ & $39,66^{\mathrm{a}}$ \\
\hline P 30F80 & $52,84^{a b c}$ & $69,47^{\mathrm{abcd}}$ & $37,00^{a b}$ \\
\hline Média & 52,84 & 71,18 & 37,28 \\
\hline $\mathrm{CV}(\%)$ & 1,17 & 4,55 & 4,15 \\
\hline
\end{tabular}

Os teores de FDNd observados em Votuporanga foram inferiores em relação às cidades de Tarumã e Mococa. Apesar disso as correlações entre os teores de FDNd da haste com os de FDN e DIVH se mostraram mais relevantes que as observadas em Tarumã e Mococa, com valores de $r=-0,82$ e $r=0,71$, respectivamente. Isso mostra que as premissas realizadas nas outras cidades referente ao teor de FDNd servem para a cidade de Votuporanga. 
Tabela 31. Coeficientes de correlação determinados entre as variáveis da haste em Votuporanga.

\begin{tabular}{|c|c|c|c|c|c|}
\hline & FDNd (H) & FDN $(\mathrm{H})$ & DIVH & MS & DPT \\
\hline$\overline{F D N d}(\mathrm{H})$ & 1 & & & & \\
\hline $\mathrm{FDN}(\mathrm{H})$ & $-0,819^{*}$ & & & & \\
\hline DIVH & $0,706^{*}$ & $-0,748^{*}$ & & & \\
\hline MS & $-0,191$ & $-0,322$ & $-0,206$ & & 1 \\
\hline DPT & $-0,093$ & 0,066 & $-0,061$ & 0,259 & \\
\hline
\end{tabular}

"Significância ao nível de 5\% de significância

FDNd $(\mathrm{H})=$ Fdn digestível da porção haste, FDN $(\mathrm{H})=$ FDN da porção haste, DIVH= digestibilidade "in vitro" da fração haste, MS = matéria seca, DPT = digestibilidade "in vitro" da planta toda

O teor de FDN médio ficou em 71,18\% entre os cultivares, valor esse inferior aos resultados dos diferentes cultivares em Tarumã, porém superiores aos resultados obtidos em Mococa. O coeficiente de correlação do FDN com a DIVH foi de $-0,75$ em Votuporanga, confirmando assim, que esse componente da haste (FDN) é o que mais afeta o consumo de matéria seca por parte dos animais e por sua vez a digestibilidade.

As DIVH se mostraram baixas (Tabela 30) quando comparadas com os resultados apresentados em Mococa e Tarumã, além das observadas por Hunt, et al., (1993) e Lundvall et al. (1994). Entretanto, as correlações entre os parâmetros da haste seguiram a mesma tendência observada nas avaliações dos resultados das cidades anteriores (Tabela 31).

\subsubsection{Estimativas de produção de leite por tonelada de MS de forragem e por hectare}

$\mathrm{Na}$ determinação da escolha de um cultivar para produção de silagem, há vários fatores qualitativos e quantitativos que interferem diretamente na produção de leite de uma propriedade. De acordo com Roth \& Lauer (1997) a alta produção de forragem é um fator essencial na obtenção do retorno produtivo por hectare. Ainda segundo Roth \& Lauer, estudos mostram que variações nas produções giram em torno de quatro a seis toneladas de $\mathrm{MS}$ ha $^{-1}$ para híbridos de milho, entretanto, a maximização do retorno produtivo não é o único papel a ser considerado. Sendo assim, a qualidade possui uma 
função preponderante no sistema produtivo, sendo que esta ganha maior importância quanto maior for a variedade de híbridos no mercado, com o objetivo de se determinar um diferencial entre os mesmos.

Com a finalidade de ajudar os produtores na determinação desse diferencial surgiram planilhas que estimam a produção de leite $\mathrm{ha}^{-1}$ e a produção de leite por tonelada de MS de forragem. Essas planilhas estimam esses parâmetros por meio de equações matemáticas que levam em consideração os teores de proteína bruta, componentes das fibras, energia e a qualidade da forragem da planta de milho expressa em digestibilidade. Nesse trabalho o cálculo de produção foi estimado através da planilha Milk 2000 (Schawb and Shaver, 2001), com alteração para o teor de FDNd, que foi determinado em laboratório.

As estimativas da produção de leite em toneladas de forragem e por hectare estão apresentadas graficamente para cada local de avaliação nesse experimento (Figuras 5, 6, 7 e 8). De acordo com Roth \& Lauer (1997) esta forma de diferenciação dos híbridos entre a produção de leite contra a qualidade da planta de milho, comumente utilizada na Universidade de Wisconsin no programa de avaliação de híbridos de milho. De acordo com esses autores o híbrido ideal seria aquele com produções por ha e por tonelada de MS maiores que a média de produção, e portanto, aqueles localizados no quadrante superior direito seriam os ideais.

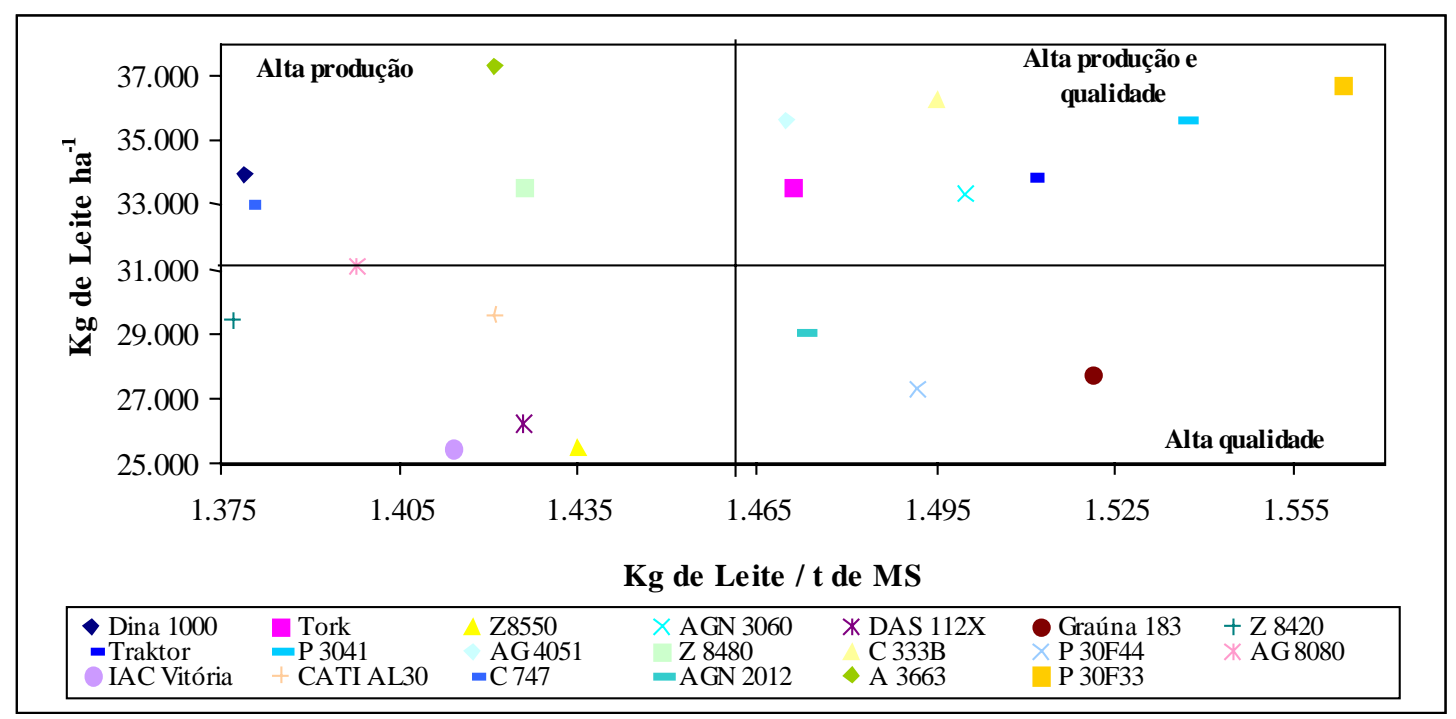

Figura 5 - Relação entre produção e qualidade da silagem de milho em Mococa. 


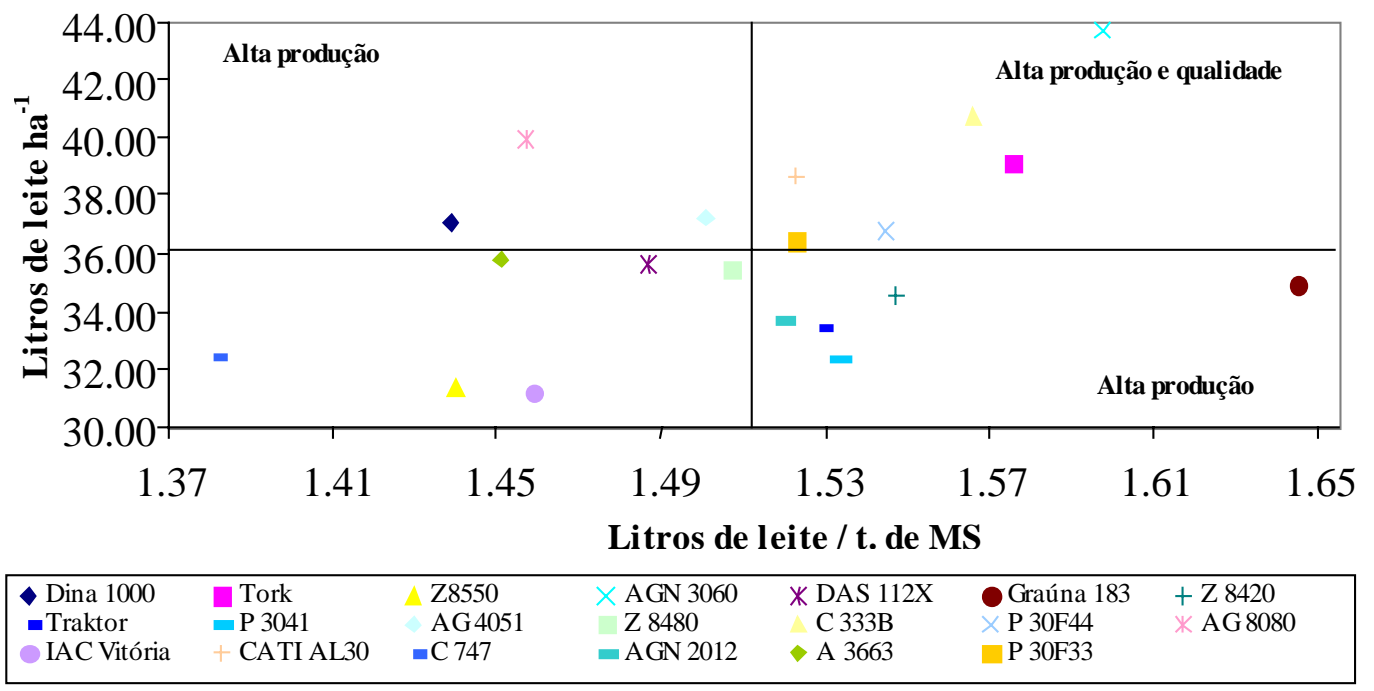

Figura 6 - Relação entre produção e qualidade da silagem de milho em Votuporanga.

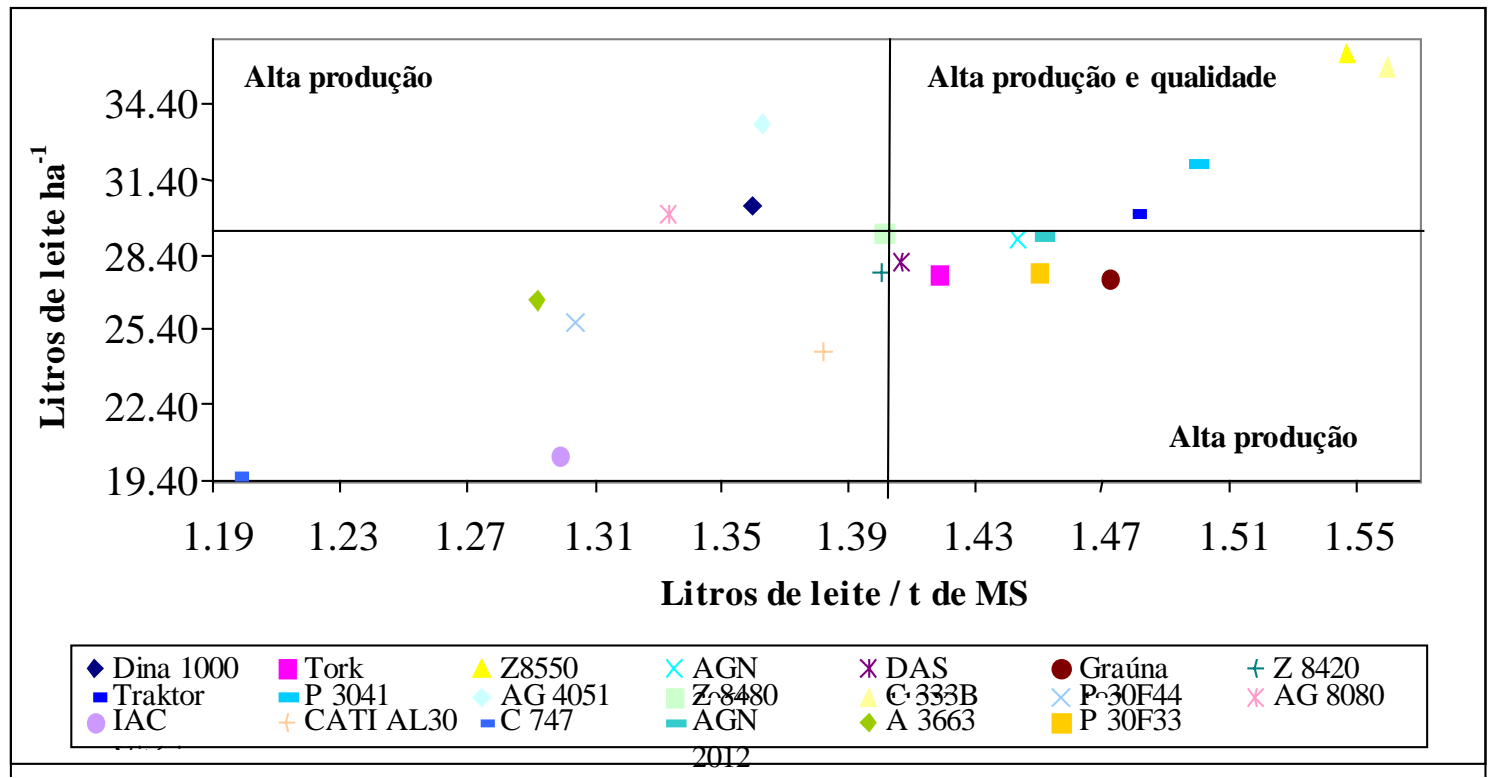

Figura 7 - Relação entre produção e qualidade da silagem de milho em Piracicaba. 


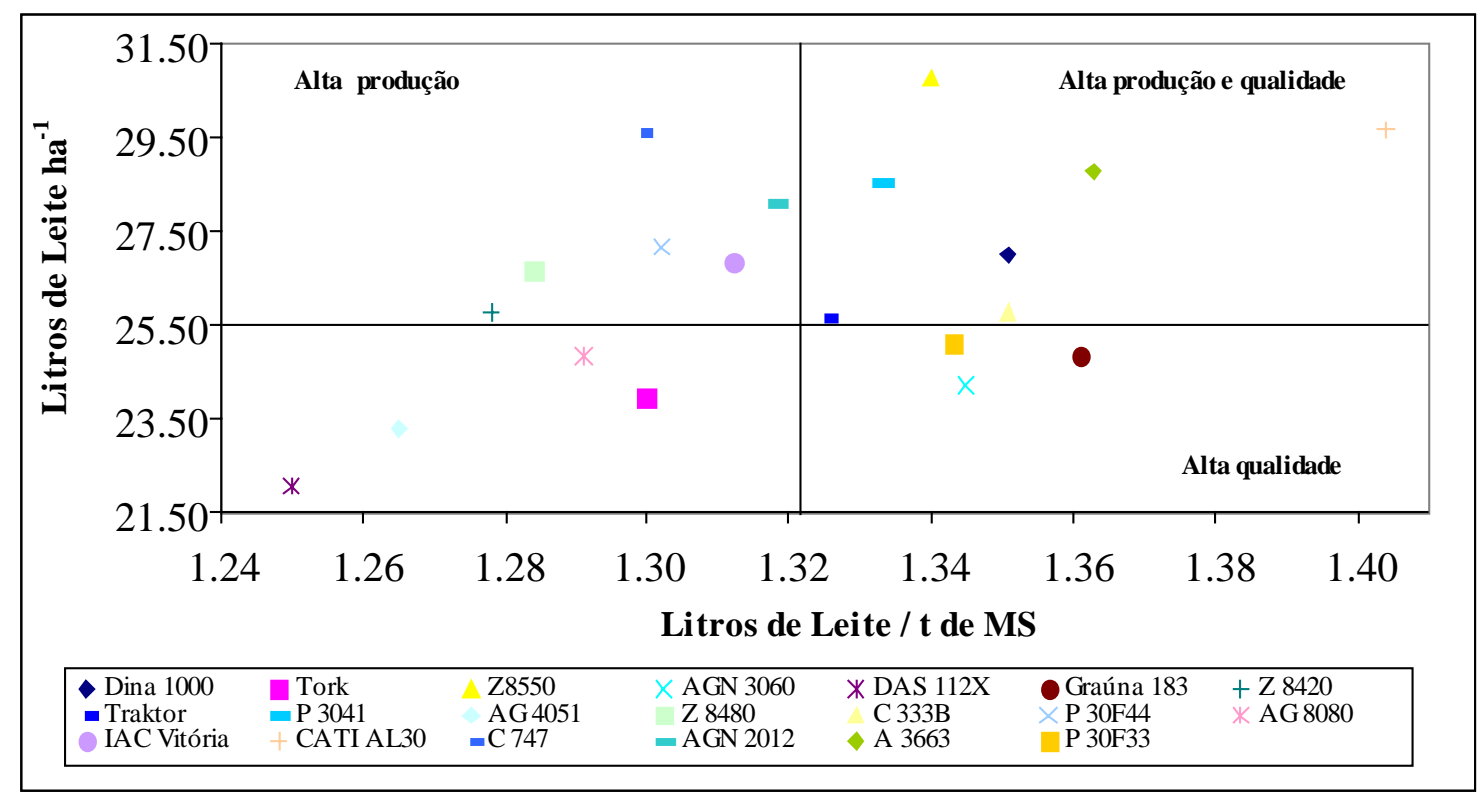

Figura 7 - Relação entre produção e qualidade da silagem de milho em Tarumã.

Os quadrantes dos gráficos de dispersão foram divididos de acordo com a média dos parâmetros produção de leite por tonelada de MS no quadrante das coordenadas, e produção de leite por hectare no quadrante das abscissas.

Através desses gráficos de dispersão, pode-se observar as diferenças ocorridas entre as produtividades de leite por hectare e por tonelada de MS nas quatro regiões analisadas. Provavelmente, estas diferenças possam ter ocorrido em função dos parâmetros qualitativos da forragem, como a digestibilidade do amido e do FDN, produtividade (produção de MS de forragem), entre outros utilizados pela planilha Milk (2000). Esses fatores são determinados pelas características fenotípicas e intrínsecas de cada cultivar aliados ao efeito climático de cada região.

Analisando os resultados de cada cidade verificou-se que em Mococa os cultivares que mais se destacaram foram o C333B, o AG4051, o Tork, o AGN3060, o Traktor, o P3041 e o P30F33 tanto em qualidade como em produtividade. Em Votuporanga a classificação se diferenciou de Mococa, tendo como resultado os cultivares Cati AL30, P30F33, P30F44, Tork e o C333B, sendo que o destaque ficou para o cultivar 
AGN3060. Em Piracicaba os cultivares que se mostraram superiores foram: o Traktor, P3041, Z8550 e o C333B. Por fim, em Tarumã o destaque foi para os cultivares Z8550, A3663, Dina1000, P3041, C333B, Traktor e o Cati AL30.

Dentre todos os cultivares analisados os que apresentaram melhores resultados, em termos de Estado de São Paulo, foram aqueles que coincidiram as suas respostas nos quatro locais avaliados, e esses foram: Traktor, P3041, e C333B. Esses cultivares apresentaram melhor aptidão para todo o Estado de São Paulo em relação aos vinte cultivares avaliados. De acordo com a súmula técnica da Pionner, o cultivar P 3041 foi o mais adaptado para Região Centro Norte, que possui como um dos Estados participantes o Estado de São Paulo. Isto demonstra que os resultados da Pionner estão condizentes com o resultado obtido nesse experimento. Resultado este que também corrobora com o obtido por Caetano (2001) que analisou onze cultivares em Jaboticabal e constatou que os melhores cultivares foram o C333B e o P3041.

A determinação da qualidade da planta de milho através da relação entre a produção de leite por t de MS de forragem e de leite por hectare (Figuras 5, 6, 7 e 8), mostrou-se similar à relação, feita anteriormente neste estudo e indicada por Nussio \& Manzano (1999) e Caetano (2001), entre a porcentagem de grãos na MS e a DIVMS (Figuras 1, 2, 3 e 4) no caso da cidade de Mococa, principalmente pelos cultivares classificados como superiores. Isto demonstra que, a escolha de cultivares de milho para produção de silagem pode ser realizada através da sua produtividade ou pela relação entre a porcentagem de grãos e a DIVMS, para cultivares com valores de digestibilidade acima de $60 \%$. 


\section{CONCLUSÕES}

Os resultados obtidos neste experimento mostraram grande variação entre os cultivares testados, especialmente na produção de MS, teor de amido e DIVMS.

Deve-se determinar o teor de MS antes do material ser colhido, mesmo através de metodologia com baixa exatidão. Somente a linha de leite não é um bom parâmetro para se estimar o ponto ideal de corte para ensilagem.

A qualidade da haste é tão importante quanto o teor de amido da planta na determinação de seu valor nutritivo.

$\mathrm{Na}$ avaliação baseada na DIVMS e porcentagem de grãos, os cultivares que se destacaram foram: C 333B, DAS 112X, Graúna 183, P 3041 e na avaliação baseada nas produções de leite por hectare e por ton de MS o Traktor, C 333B e P 3041. 


\section{REFERÊNCIAS BIBLIOGRÁFICAS}

ALLEN, M.S.; OBA, M.; CHOI, B.R.C. Nutritionist's perspective of corn hybrids for silage. In: NORTH AMERICAN CONFERENE, Ithaca, 1997. Proceedings. Ithaca: NRAES, 1997. p. 15-24

ALLEN, M.S.; O'NEIL, K.A.; MAIN, D.G.; BECK, J. Variation in fiber fractions and "in vitro" true and cell wall digestibility of corn silage hybrids. Journal of Dairy Science, v. 73, suppl. 1, p.129, 1990.

ALLEN, M.S.; O`NEIL, K.A.; MAIN, D.G.; BECK, J. Relationship among yield and quality traits of corn hybrids for silage. Journal of Dairy Science, v. 74, suppl. 1, p. $221,1991$.

ALMEIDA, J.C.C. Avaliação das características agronômicas e das silagens de milho e de sorgo cultivados em quatro densidades de semeadura. Jaboticabal, 2000. 82p. Tese (Doutorado) - Faculdade de Ciências Agrárias e Veterinárias, Universidade Estadual Paulista "Julio de Mesquita Filho".

ALMEIDA FILHO, S.L. Avaliação de cultivares de milho (Zea Mays L.) para silagem. Viçosa, 1996. 53p. Dissertação (M.S.) - Universidade Federal de Viçosa. 
ALMEIDA FILHO, S.L.; FONSECA, D.M.; GARCIA, R.; OBEID, J.A.; OLIVEIRA, J.S. Características agronômicas de cultivares de milho (Zea mays L.) e qualidade dos componentes da silagem. Revista Brasileira de Zootecnia, v. 28, n.1, p. 7-13, 1999.

ANDRAE, J.G.; HUNT, C.W.; PRITCHARD; KENNINGTON, L.R.; HARRISON, J.H.; KEZAR, W.; MAHANNA, W. Effect of hybrid, maturity, and mechanical processing of corn silage on intake and digestibility by beef cattle. Journal of Animal Science, v. 79, p. 2268-2275, 2001.

ASSOCIATION OF OFFICIAL ANALYTICAL CHEMISTS. Official methods of analysis. 13. ed. Washington, 1980. p. 905.

BAL, M.A.; SAHVER R.D.; SHINNERS, K.J.; COORS, J.G; LAUER, J.G.; STRAUB, R.J.; KOEGEL, R.G. Stage of maturity, processing, and hybrid effects on ruminal in situ disappearance of whole-plant corn silage. Animal Feed Science and Technology, v.86, p. 83-94, 2000.

BALLARD, C.S.; THOMAS, E.D.; TSANG, D.S.; MANDEBVU, P.; SNIFFEN, C.J.; ENDRES, M.I.; CARTER, M.P. Effect of corn hybrid on dry matter yield, nutrient composition, "in vitro" digestion, intake by dairy heifers, and milk production for dairy cows. Journal of Dairy Science, v. 84, p. 442-452, 2001.

BARTON, F. E. Considerations of chemical analyses: near infrared reflectance spectroscopy (NIRS). analysis of forage quality. Washington: USDA, ARS, 1989. 68p. (Handbook, 643).

CAETANO, H. Avaliação de onze cultivares de milho colhidos em duas alturas de corte para a produção de silagem. Jaboticabal, 2001. 178p. Tese (Doutorado) - Faculdade de Ciências Agrárias e Veterinárias, Universidade Estadual Paulista "Julio de Mesquita Filho".

COORS, J.G. Analitycal methodologies to analyse forages and grains. In: CORNELL NUTRITION CONFERENCE, 58., PIONNER HI-BRED INTERNACIONAL PRECONFERENCE SYMPOSIUM, Ithaca, 1996. Proceedings. Ithaca: Cornell University, 1996. p. 20-28. 
COORS, J.G.; ALBRECHT, K.A.; BURES, E.J. Ear-fill effects on yield and quality of silage corn. Crop Science, v. 37, p. 243-247, 1997.

COSTA, R.C. Avaliação de características agronômicas e bromatológicas de cultivares de milho - safra 97-98. Belo Horizonte, 2000. 83p. Dissertação (Mestrado) - Escola de Veterinária, Universidade Federal de Minas Gerais.

COX, W.J.; CHERNEY, J.H.; CHERNEY, D.J.R.; PARDEE, W.D. Forage quality and harvest index of corn hybrids under different growing conditions. Agronomy Journal, v. 86, p.277-282, 1994.

CRASTA, O.R.; COX, W.J.; CHERNEY, J.H. Factors affecting maize forage development in the northeastern USA. Agronomy Journal, v. 89, p. 251-256, 1997.

DAYNARD, T.B.; HUNTER, R.B. Relationships among whole-plant moisture, grain moisture, dry matter yield, and quality of whole-plant corn silage. Canadian Journal of Plant Science. v. 55, p.77-84, 1975.

DEINUM, B. Genetic and environmental variation in quality of forage made in Europe. Netherlands Journal of Agriculture Science, v. 36, p. 400-403, 1988.

EMPRESA BRASILEIRA DE PESQUISA AGROPECUÁRIA. Centro Nacional de Pesquisa de Solos. Manual de métodos de análise de solos. 2. ed. Rio de Janeiro: Embrapa, CNPS., 1997. 212p. (Embrapa.CNPS. Documentos, 1).

FANCELli, A.L., DOURADO NETO, D. Produção de milho. Guaíba: Editora Agropecuária, 2000. 360p.

GIVENS, D.I.; DEAVILLE, E.R. Comparison of major carbohydrate fractions and cell wall digestibility in silages made from older and newer genotypes grown in UK. Animal Feed Science and Technology, v. 89, p. 69-82, 2001.

HENRIQUE, W.; COUTINHO FILHO, J.L.V.; JUSTO, C.L. Avaliação da produtividade, porcentagem de grãos na massa, qualidade da silagem e produção de grãos de onze híbridos de milho. In: REUNIÃO ANUAL DA SOCIEDADE BRASILEIRA DE ZOOTECNIA, 34., Juiz de Fora, 1997. Anais. Juiz de Fora: SBZ, 1997. p.173-175. 
HUNT, C.W.; KEZAR, W.; HINMAN, D.D.; COMBS, J.J.; LOESCHE, A.; MOEN, T. Effects of hybrid and ensiling with and without a microbial inoculant on the nutritional characteristics of whole-plant corn. Journal of Animal Science, v. 71, p. 38-43, 1993.

HUNT, C.W.; KEZAR, W.; VINADE, R. Yield, chemical composition and ruminal fermentability of corn whole plant, ear, and stover as affect by maturity. Journal of Production Agriculture, v. 2, p. 357-361, 1989.

HUNT, C.W.; KEZAR, W.; VINANDE, R. Yield, chemical composition and ruminal fermentability of corn whole plant, ear, and stover as affect by hybrid. Journal of Production Agriculture, v. 6, p. 286-295, 1992.

HUNTER, R.B. Selection and evaluation procedures for whole-plant corn silage. Canadian Journal of Plant Science, v. 58, p. 661-678, 1978.

JOHNSON, J.C.; GATES, R.N.; NEWTON, G.L.; WILSON, J.P.; CHANDLER, L.D.; UTLEY, P.R. Yield, composition, and "in vitro" digestibility of temperate and tropical corn hybrids grown as silage crops planted in summer. Journal of Dairy Science, v. 80, p.550-557, 1997.

JOHNSON, L.; HARRISON, J.H.; HUNT, C.; SHINNERS, K.; DOGGETT, C. G.; SAPIENZA, D. Nutritive Value of corn silage as affected by maturity and mechanical processing: A Contemporary Review. Journal of Dairy Science, v. 82, p. 2813-2825, 1999.

JUNG, H.G.; MERTENS, D.R.; BUXTON, D.R. Forage quality variation among maize inbreds: in vitro fiber digestion kinetics and prediction with NIRS. Crop Science, v. 38, p. 205-210, 1998.

KUEHN, C.S.; LINN, J.G.; HALLAND, S.K.; JUNG, H.G. Quality measures in corn silage samples from two growing seasons. Journal of Dairy Science. v. 79, suppl. 1, p. 150, 1996.

LAUER, J. Calculating silage value of immature corn (continued). http://corn.agronomy.wisc.edu/Publications/WCM/1996/calculatingsilagevalueofimmat urecorn.htm (20/abril/2002). 
LAUER, J.G.; COORS, J.G.; FLANNERY, P.J. Forage yield and quality of corn cultivars developed in different eras. Crop Science, v. 41, p.1449-1455, 2001.

LAVEZZO, O.E.N.M.; LAVEZZO, W.; SIQUEIRA, E.R. de. Estádio de desenvolvimento do milho.2. Efeito sobre o consumo e a digestibilidade da silagem em ovinos. Revista Brasileira de Zootecnia, v. 26,n. 4, p.683-690, 1997b.

LAVEZZO.W; LAVEZZO, O.E.N.M.; SIQUEIRA, E.R. de. Estádio de desenvolvimento do milho.1. Efeito sobre a produção, composição da planta e qualidade da silagem. Revista Brasileira de Zootecnia, v. 26,n. 4, p.675-682, 1997a.

LUNDEEN, T. relative feed values for corn silage varieties differ by evaluation method. Feedstuffs, v.10, p. 17-18, May 2000.

LUNDVALL, J.P.; BUXTON, D.R.; HALLAUER, A.R.; GEORGE, J.R. Forage quality among inbreds: "in vitro" digestibility and cell wall components. Crop Science, v. 34, p. 1672-1678, 1994.

MAHANNA, B. Corn silage - managing and feeding the "TMR plant". http://www.pioneer.com/consult/research/wpcs2.htm (23/nov./1996).

MC DONALD, P., HENDERSON A R.; HERON E S. J. I991. Biochemistry of silage. 2. ed. Marlow: Chalcombe Publication, 1991.

MOREIRA, V.R. Utilização de silagem de milho para vacas leiteiras de alta produção. Belo Horizonte, 2000. 89p. Tese (Doutorado) - Escola de Veterinária, Universidade Federal de Minas Gerais.

NUSSIO, L.C. Avaliação de cultivares de milho (Zea Mays L.) para ensilagem através da composição química e digestibilidade “in situ”. Piracicaba, 1997, Dissertação (Mestrado) - Escola Superior de Agricultura Luiz de Queiroz, Universidade de São Paulo.

NUSSIO, L.G. A cultura do milho e sorgo para a produção de silagem. In: FANCELLI, A.L. (Coord.) Milho. Piracicaba: FEALQ, 1990. 88p. 
NUSSIO, L.G.; MANZANO, R.P. Silagem de milho. In: SIMPÓSIO SOBRE NUTRIÇÃO DE BOVINOS, 7., Piracicaba, 1999. Alimentação suplementar. Piracicaba: FEALQ, 1999. p.27-46.

NUSSIO, L.G.; DE CAMPOS, F.P.; DIAS F.N. Importância da qualidade da porção vegetativa no valor alimentício da silagem de milho. In: SIMPÓSIO SOBRE PRODUÇÃO E UTILIZAÇÃO DE FORRAGENS CONSERVADAS, Maringá, 2001. Anais. Maringá: Universidade de Maringá, 2001. p. 127-144.

NUSSIO, L.G.; SIMAS, J.M. de; LIMA, M.L.M. Determinação do ponto de maturidade ideal para colheita do milho para silagem. In: Workshop sobre milho para silagem, 2. Piracicaba, 2000. Anais. Piracicaba: FEALQ, 2001. p. 11-26.

OLIVEIRA, J.S.; BRAGA, R.A.N.; LOPES, F.C.F.; VITTORI, A.; RESENDE, H. Avaliação da qualidade da planta de milho para silagem. In: REUNIÃO ANUAL DA SOCIEDADE BRASILEIRA DE ZOOTECNIA, 34., Juiz de Fora, 1997. Anais. Juiz de Fora: SBZ, 1997. p.161-163.

PENATI, M.A. Relação de alguns parâmetros agronômicos e bromatológicos de híbridos de milho (Zea mays L.) com a produção, digestibilidade e teor de matéria seca da planta. Piracicaba, 1994. 97p. Dissertação (Mestrado) - Escola Superior de Agricultura "Luiz de Queiroz", Universidade de São Paulo.

PEREIRA, J.R.A.; FONSECA, M.P.; REIS, R.A.; RODRIGUES, L.R.A.; RESENDE, K.T. Avaliação da produção de forragem e composição química de três cultivares de milho. In: REUNIÃO ANUAL DA SOCIEDADE BRASILEIRA DE ZOOTECNIA, 34., Juiz de Fora, 1997. Anais. Juiz de Fora: SBZ, 1997a. p.167-169.

PHILIPPEAU, C.; MICHALET-DOREAU, B. Influence of genotype and stage of maturity of maize on rate of ruminal starch degradation. Animal Feed Science and Technology, v. 68, p. 25-35, 1997.

POORE, M. H.; ECK, T. P.; SWINGLE, R. S.; THEURER, C. B. Total starch and relative starch availability of feed grains. In: BIENNAL CONFERENCE ON RUMEN FUNCTION, 20., Chicago, 1989. Abstracts. Washington: USDA, 1998. 
RENTERO, N. Qualidade total: a nova referência das silagens. Balde Branco, p. 22, maio 1998.

ROTH, G.W.; LAUER, J. G. 1997. Agronomist's perspective of corn hybrids for silage. In: NORTH AMERICAN CONFERENE, Ithaca, 1997. Proceedings. Ithaca: NRAES, 1997. p. 15-24.

RUSSEL, J.R. Influence of harvest date on the nutritive value and ensiling characteristics of maize stover. Animal Feed Science and Technology, v. 14, p. 11-27, 1986.

RUSSELL, J.R.; IRLBECK, N.A.; HALLAUER, A.R.; BUXTON, D.R. Nutritive value and ensiling characteristics of maize as influenced by agronomic factors. Animal Feed Science and Technology, 38,p. 11-24, 1992.

RUSSO, H.G. Efeito de três densidades de plantio sobre a produção e composição bromatológica de milho granífero e forrageiro sobre a qualidade e valor nutritivo e suas silagens. Botucatu, 1995. 110 p. Tese (Doutorado) - Faculdade de Medicina Veterinária e Zootecnia, Universidade Estadual Paulista "Júlio de Mesquita Filho".

SANTOS, I.R. dos; PERREIRA, J.R.A. Avaliação de híbridos de milho para silagem. http://www.fundacaoabc.com.br/artigos/nutricao/silagens.htm. (15/abril/2002).

SAPIENZA, D.A. Analitycal methodologies to analyse forages and grains. In: CORNELL NUTRITION CONFERENCE, 58; PIONNER HI-BRED INTERNACIONAL PRECONFERENCE SYMPOSIUM, Ithaca, 1996. Proceedings. Ithaca: Cornell University, 1996. p. 10-19.

sas institute. SAS: users guide; statistics. 5.ed. Cary, 1999. 213p.

SCHMID, A.R.; GOODRICH, R.D.; JORDAN, R.M.; MARTEN, G.C.; MEISKE, J.C. Relationship among agronomic characteristics of corn and sorghum cultivars and silage quality. Agronomy Journal, v. 68, p.403-406, 1976.

SEGLAR, B. Corn silage management to maximize milk production - Part 2: Proper hybrid selection. http://www.pioneer.com/usa/nutrition/silage_milk_hybrid.htm (17/março/2000). 
SHAVER, R.D. Silage management for maximum yield. In: NOVOS ENFOQUES SOBRE REPRODUÇÃO E NUTRIÇÃO DE BOVINOS, Passos, 1999.

SHAVER, R.D.; Undersander, D.; SCHWAB, E.; HOFFMAN, P.; LAUER, J.; COMBS, D.; COORS, J. Milk 2000: Combining yield and quality into a single term. http:// www.uwex.edu/ces/forage/pubs/milk2000.htm (20/novembro/2001)

SILVA, L.F.P. e. Avaliação de características agronômicas e nutricionais de híbridos de milho para silagem. Piracicaba, 1997. 98p. Dissertação (Mestrado) - Escola Superior de Agricultura “Luiz de Queiroz", Universidade de São Paulo.

SILVA, L.F.P. e; MACHADO, P.F.; FERNADES JÚNIOR, J.C.de; MELCHIADES, T.D.Avaliação da qualidade da forragem de híbridos de milho: digestibilidade "in situ" e componentes da parede celular. In: REUNIÃO ANUAL DA SOCIEDADE BRASILEIRA DE ZOOTECNIA, 34., Juiz de Fora, 1997. Anais. Juiz de Fora: SBZ, 1997. p.176-178.

SONON, R.N.; DALKE, B.S.; BOLSEN, K.K.; BOYER, J.E. Effect of grain on the nutritive value of whole-plant corn silage. Journal of Animal Science, v.71, suppl. 1, p. 266, 1993.

SULC, R.M.; THOMISON, P.R.; WEISS, W.P. Reliability of the kernel milk line method for timing corn silage harvest in Ohio. Journal of Production Agriculture, v.9, n.3, p.376-381, 1996.

TEMPLETON Jr., W.C.; SHENK, J. S.; NORRIS, K. H. Forage analyses with nearinfrared reflectance spectroscopy - status and outline of national research project. In: INTERNACIONAL GRASSLAND CONGRESS, 14., Lexington, 1983. Proceedings. Lexington: Westview Press, 1983. p. 528.

THOMAS, E.D.; MANDEBVU, P.; BALLARD, C.S.; SNIFFEN, C.J.; CARTER, M.P.; BECK, J. Comparison of corn silage hybrids for yield, nutrient composition, "in vitro" digestibility, and milk yield by dairy cows. Journal of Dairy Science, v. 84, p. 22172226, 2001. 
TOLERA, A.; SUNDSTOL, F. Morphological fractions of maize stover harvested at different stages of grain maturity and nutritive value of different fractions of the stover. Animal Feed Science and Technology, v. 81, p. 1-16, 1999.

TOVAR-GÓMEZ, M.R.; EMILE, J.C.; MICHALET-DOREAU, B.; BARRIÈRE,Y. In situ degradation kinetics of maize hybrid stalks. Animal Feed Science and Tecchnology, v.68, p. 77-88, 1997.

VAN SOEST, P. J.; ROBERTSON, J. B.; LEWIS, B. A. Methods for dietary fiber, neutral detergent fiber, and nonstarch polissacharides in relation to animal nutrition. Journal of Dairy Science, v. 74, p. 3583 - 3591, 1991.

VATTIKONDA, M.R.; HUNTER, R.B. Comparison of grain yield and wholw-plant silage production of recommended corn hybrid. Canadian Journal of Plant Science. v. 63, p. 601-609, 1983.

WEISS, W.P. Estimating the available energy content of feeds for dairy cattle. Journal of Dairy Science, v. 81, p. 830 - 839, 1998.

WOLF, D.P.; COORS, J.G.; ALBRECHT, K.A.; UNDESANDER, D.J.; CARTER, P.R. Forage quality of mayze genotypes selected for extreme fiber concentrations. Crop Science, v. 33, p. 1353-1359, 1993a.

WOLF, D.P.; COORS, J.G.; ALBRECHT, K.A.; UNDESANDER, D.J.; CARTER, P.R. Agronomic evaluations of maize genotypes selected for extreme fiber concentrations. Crop Science, v. 33, p. 1359-1365, 1993 b. 


\section{APÊNDICES}


Apêndice 1.

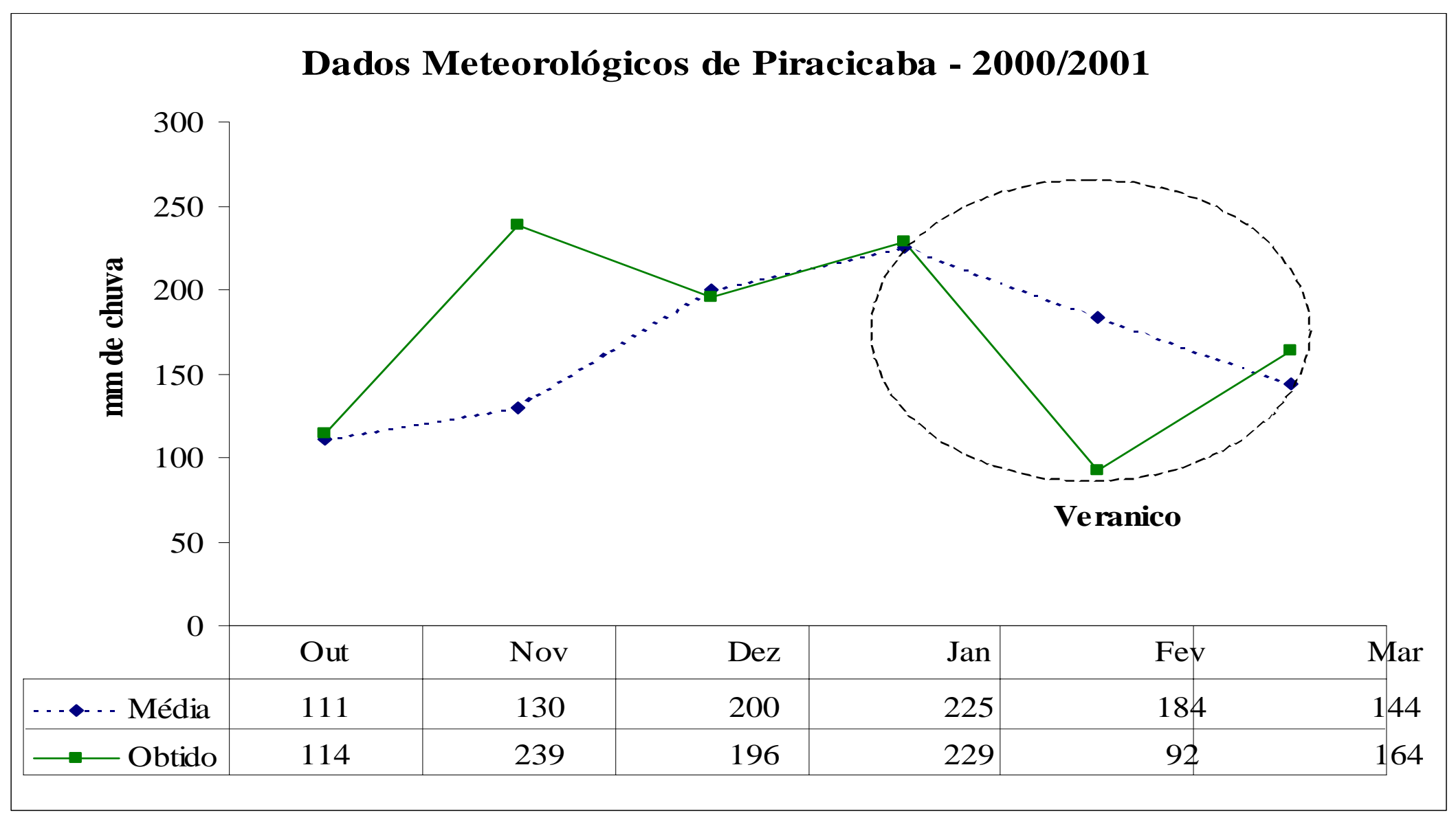


Apêndice 2.

Porcentagem de MS das frações agronômicas dos cultivares de milho em Votuporanga

\begin{tabular}{ccccc}
\hline Cultivar & g+s & Folha & Haste & Bráctea \\
\hline & $-------------\%$ MS & ----------- \\
AG 8080 & 57,4 & 31,4 & 25,9 & 35,5 \\
AGN 3060 & 60,5 & 36,7 & 26,6 & 41,0 \\
C 333 B & 61,5 & 37,2 & 23,7 & 45,2 \\
Dina 1000 & 51,8 & 31,3 & 24,8 & 32,4 \\
CATI AL 30 & 56,7 & 35,0 & 25,0 & 37,2 \\
A 3663 & 60,2 & 29,5 & 23,9 & 36,4 \\
Tork & 61,5 & 42,1 & 25,9 & 51,0 \\
AG 4051 & 57,5 & 35,5 & 25,6 & 46,1 \\
Z 8480 & 63,9 & 34,6 & 34,8 & 54,0 \\
P 30F80 & 57,6 & 28,3 & 24,2 & 30,3 \\
P 30F44 & 55,9 & 35,8 & 20,0 & 32,0 \\
DAS 112 X & 57,3 & 36,5 & 23,1 & 33,9 \\
C 747 & 54,5 & 31,8 & 24,8 & 34,3 \\
Z 8420 & 59,3 & 33,3 & 21,9 & 35,1 \\
AGN 2012 & 52,1 & 28,3 & 24,5 & 31,3 \\
Traktor & 56,1 & 32,1 & 22,0 & 28,6 \\
IAC Vitória & 57,6 & 32,7 & 23,9 & 37,7 \\
Graúna 183 & 59,0 & 29,4 & 20,2 & 31,5 \\
P 3041 & 55,0 & 30,9 & 22,5 & 30,9 \\
Z 8550 & 54,4 & 31,1 & 23,2 & 30,2 \\
Média & 57,5 & 33,2 & 24,3 & 36,7 \\
\hline
\end{tabular}

